Article

\title{
Design, Synthesis, Antitumor Activity and Molecular Docking Study of Novel 5-Deazaalloxazine Analogs
}

\author{
Sawsan Mahmoud ${ }^{1}$, Doaa Samaha ${ }^{1,2}$, Mosaad S. Mohamed ${ }^{3}$, Nageh A. Abou Taleb ${ }^{1}$, \\ Mohamed A. Elsawy ${ }^{4,5}$, Tomohisa Nagamatsu ${ }^{6}$ and Hamed I. Ali ${ }^{7, *}$ \\ 1 Pharmaceutical Chemistry Department, Faculty of Pharmacy, Helwan University, Helwan 11795, Egypt; \\ sawsansf@yahoo.com (S.M.); samahado@student.hu-berlin.de (D.S.); \\ dr.nagehabotaleb@yahoo.com (N.A.A.T.) \\ 2 Institute of Chemistry, Humboldt-Universität zu Berlin, Brook-Taylor-Str. 2, 12489 Berlin, Germany \\ 3 Pharmaceutical Organic Chemistry Department, Faculty of Pharmacy, Helwan University, \\ Helwan 11795, Egypt; doctormosaad@hotmail.com \\ 4 School of Pharmacy, Queen's University of Belfast, 97 Lisburn Road, Belfast BT9 7BL, UK; \\ melsawy01@qub.ac.uk \\ 5 Leicester Institute of Pharmaceutical Innovation, Leicester School of Pharmacy, De Monfort University, \\ The Gateway, Leicester LE1 9BH, UK \\ 6 Department of Medical Technology, Faculty of Health Science, Kumamoto Health Science University, \\ Kumamoto 861-5598, Japan; nagamatu@kumamoto-hsu.ac.jp \\ 7 Irma Lerma Rangel College of Pharmacy, Texas A\&M University, College Station, Kingsville, TX 78363, USA \\ * Correspondence: alyismail@tamu.edu; Tel.: +136-196-05082; Fax: +136-159-34303
}

Academic Editor: Maria Cristina De Rosa

Received: 26 April 2020; Accepted: 25 May 2020; Published: 28 May 2020

Abstract: Protein tyrosine kinases (PTKs) are the most potential therapeutic targets for cancer. Herein, we present a sound rationale for synthesis of a series of novel 2-(methylthio), 2-(substituted alkylamino), 2-(heterocyclic substituted), 2-amino, 2,4-dioxo and 2-deoxo-5-deazaalloxazine derivatives by applying structure-based drug design (SBDD) using AutoDock 4.2. Their antitumor activities against human CCRF-HSB-2, KB, MCF-7 and HeLa have been investigated in vitro. Many 5-deazaalloxazine analogs revealed high selective activities against MCF-7 tumor cell lines ( $\mathrm{IC}_{50}$ : 0.17-2.17 $\mu \mathrm{M}$ ) over HeLa tumor cell lines $\left(\mathrm{IC}_{50}>100 \mu \mathrm{M}\right)$. Protein kinase profiling revealed that compound $3 \mathrm{~h}$ induced multitargets kinase inhibition including $-43 \%$ against (FAK), $-40 \%$ against (CDKI) and $-36 \%$ against (SCR). Moreover, the Annexin-V/PI apoptotic assay elucidate that compound $3 \mathrm{~h}$ showed $33 \%$ and potentially $140 \%$ increase in early and late apoptosis to MCF-7 cells respectively, compared to the control. The structure-activity relationship (SAR) and molecular docking study using PTK as a target enzyme for the synthesized 7-deazaalloaxazine derivatives were investigated as potential antitumor agents. The AutoDock binding affinities of the 5-deazaalloxazine analogs into c-kit PTK (PDB code: $1 \mathrm{t} 46)$ revealed reasonable correlations between their AutoDock binding free energy and $\mathrm{IC}_{50}$.

Keywords: deazaalloxazine; antitumor; AutoDock; selectivity; protein kinase

\section{Introduction}

Cancer is a severe health problem in the United States. In 2020, there have been more than 1.8 million new cases diagnosed with cancer and nearly 606,520 died from it in the US [1]. The implication of protein tyrosine kinases (PTKs in various forms of cancers made them significant targets in drug discovery. The selective PTK inhibitors are prospective candidates as antitumor agents by inhibiting multiple pathways in cancer cells, such as proliferation, survival and angiogenesis [2]. Consequently, the synthesis of small molecules as PTK inhibitors (PTKIs) has developed into a remarkable approach toward new therapeutics [3]. After the Food and Drug Administration (FDA) approval for imatinib in 
2001, they become a trend as potential anticancer drugs to the market [4]. Nowadays, there are more than twenty FDA-approved PTKIs for cancer therapy [5].

Interestingly, the in vivo antitumor activity of 2-deoxo-10-methyl-2-phenyl- 5-deazaflavin (I) against subcutaneously transplanted human adenocarcinoma A431 xenograft into BALB/c nude mice was reported early by our research group [6]. In this study, the tumor volume was reduced to $53.4 \%$ of the intraperitoneal administration after 10 days $(100 \mathrm{mg} / \mathrm{kg}$; i.p.) as shown in Figure 1. Furthermore, we investigated the antitumor activities of 5-deazaflavins and flavins derivatives against a variety of cancer cell lines and elucidated that these candidates could be promising antitumor drugs $[7,8]$.

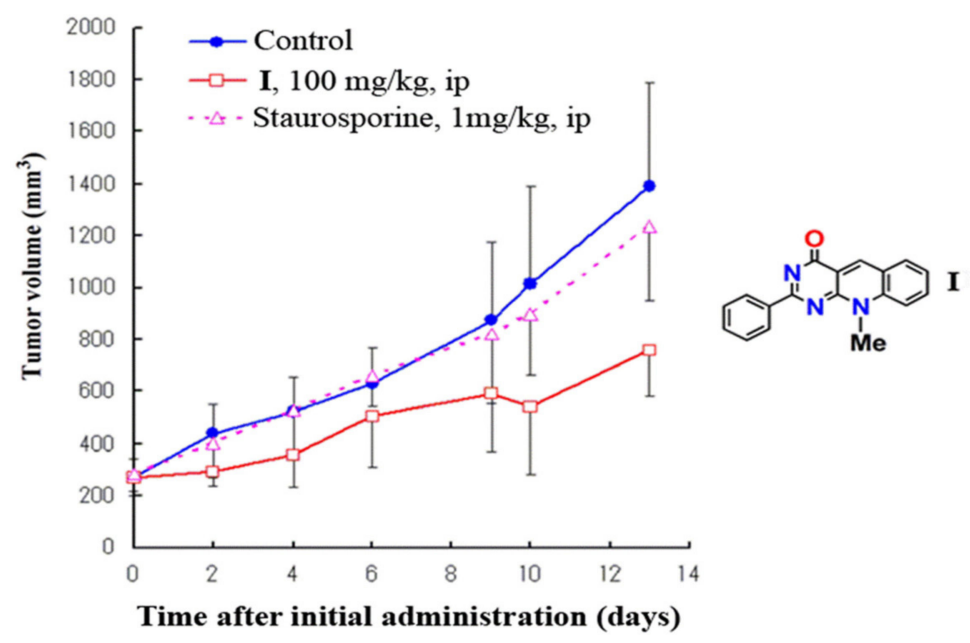

Figure 1. One hundred $\mathrm{mg} / \mathrm{kg}$, i.p., of compound I reduced the tumor volume of Subcutaneous (SC) implanted A431 into nude mouse $53.4 \%$ after 10 days of $100 \mathrm{mg} / \mathrm{kg}$, ip.

The potential antitumor activity of 5-deazaalloxazines \{pyrimido[4,5- $b$ ] quinoline-2,4 $(1 \mathrm{H}$, $3 H$ )-diones $\}$ is attributed to their structural similarities with the scaffold of 5-deazaflavins \{pyrimido[4,5- $b$ ] quinoline-2,4 $(3 H, 10 H)$-diones\} [9]. The condensed pyrimido[4,5- $b$ ] quinoxaline cyclic systems are called "alloxazines" which exist in two tautomeric forms, one of which, when "frozen" by substitution of the hydrogen atom at $\mathrm{N}(10)$, is the source of the isoalloxazine series [10] as shown in Figure 2.

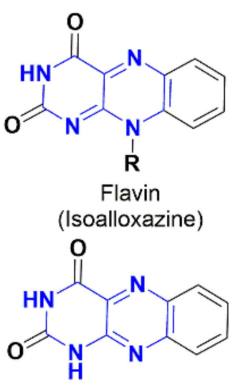

Alloxazine
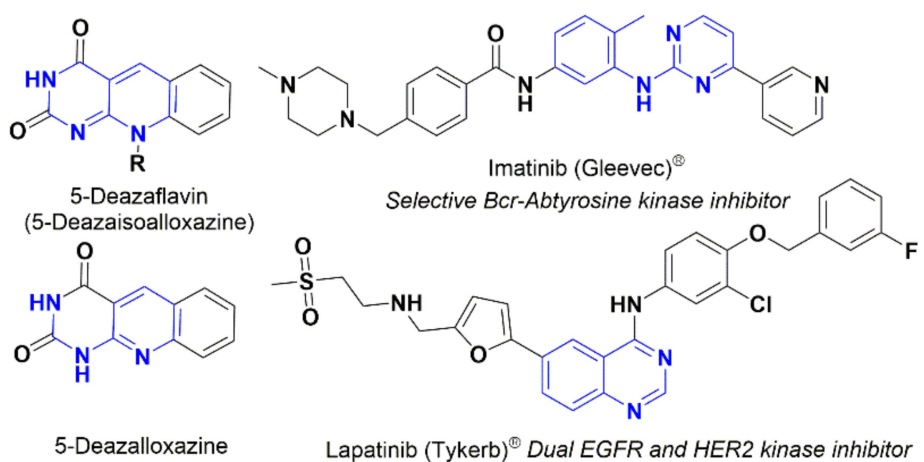

Figure 2. Structures of flavin, 5-deazaflavin, alloxazine, 5-deazaalloxazins and the well-known kinase inhibitors (imatinib and lapatinib).

Computer-aided drug design (CADD) is a powerful model for drug discovery, where several computationally designed drugs are currently under clinical investigations and even marketed, such as Dorzolamide, Saquinavir, Aliskiren [11,12]. Recent applications of computational chemistry comprising both Structure-Based Drug Design (SBDD) and Ligand-Based Drug Design (LBDD) approaches in the discovery and design of kinase inhibitors were intensively implemented in the design and discovery 
of many kinase inhibitors such as imatinib (Figure 2) [13,14]. Multi-targeted therapy is a powerful category for eradication of cancer cells; therefore, CADD tools are fundamental in the discovery and development of anticancer drugs [15-17]. SBDD techniques such as homology modeling, molecular dynamics (MD) simulations and docking have been applied for lead optimization based on the binding sites of therapeutic target proteins [18-20]. Molecular docking is the most advanced technique for lead optimization by investigation of the binding affinities of compounds into the binding cavities of the therapeutic target protein. AutoDock is the most commonly cited software docking program in the scientific literature Figure 3 [21]. The docking binding affinity studies for many 5-deazaflavin derivatives into PTK have been reported [10,22-24].

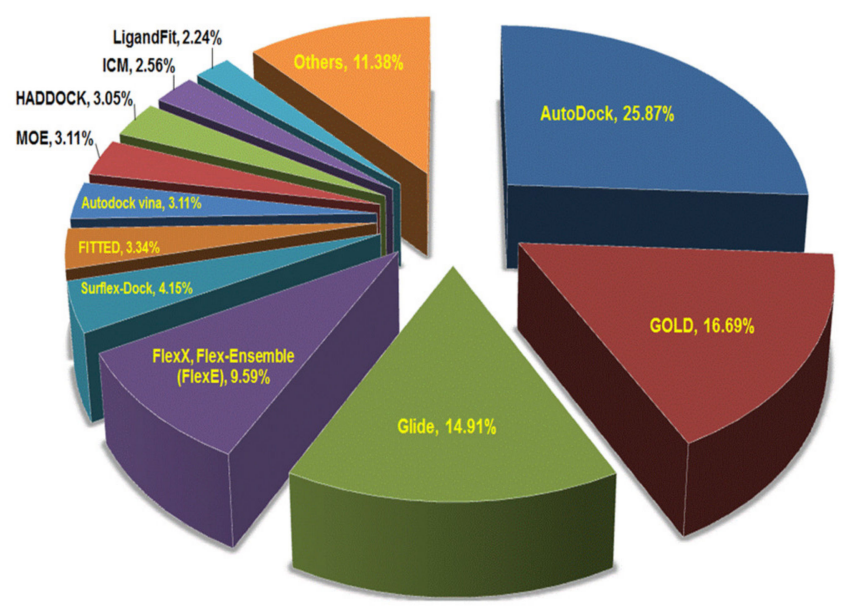

Figure 3. The rate of citation of different molecular docking programs, in which Autodock, GOLD and Glide are the most commonly used ones, modified through reference [21].

For the aforementioned facts, new derivatives of flavin and deazaflavin derivatives compounds are still in demand to enhance their binding affinity into the targeted kinases and consequently their and the antitumor activities. Moreover, our earlier results [7] have identified several key features through Structure Activity Relationship (SAR) study of the different flavin analogs to impact the maximum binding affinity by the following structural characteristics: (1) no substituent at the N-10 position on 5-deazaflavins, flavins and flavin-5-oxide analogs, (2) hydrogen at the N-3 position, (3) $\mathrm{Ph}_{\text {or }} \mathrm{NH}_{2}$ group at the C-2 position. These preliminary studies prompted us to synthesize new 5-deazaalloxazines analogs based on SBDD for structural optimization of our reported compounds to reveal higher selectivity against different kinases and tumor cell lines.

\section{Results and Discussion}

\subsection{Synthesis and Structural Elucidation of 5-Deazaalloxazine Derivatives}

The prerequisite starting material, 6-(N-alkylanilino)-2-methylthiopyrimidin- $4(3 \mathrm{H})$-ones (1a-e) were prepared by alkylation of 2,3-dihydro-6-( $N$-arylamino)-2-thioxopyrimidin-4(1H)-ones [8] with alkyl iodide in $2 \mathrm{M} \mathrm{NaOH}$ at $0-5{ }^{\circ} \mathrm{C}$ for $30 \mathrm{~min}$ in $61-90 \%$ yields [21]. The intermediate compounds, 2-deoxo-2-alkylthio-5- deazaalloxazines (2a-e) were prepared according to the reported method $[10,13]$ by the reaction of 6-(N-alkylanilino)-2-alkylthiopyrimidin-4(3H)-ones (1a-e) with Vilsmier reagent (dimethylformamide-phosphorus oxycholride-DMF-POCl 3 ) at $90{ }^{\circ} \mathrm{C}$ for $1-4 \mathrm{~h}$ in $72-86 \%$ yields. Amination of 2-alkylthiopyrimidine and 5-deazaalloxazine analogs via reaction with different alkyl and aryl amines has long been investigated $[8,25,26]$. The carbons adjacent to nitrogens of pyrimidine moieties of 5-deazaalloaxzine are susceptible to nucleophilic substitution reactions because of the $\pi$ electron-deficient nature. Thus, the different amination reactions have been done by substitution of 2-methylthio group with different amines for preparation of 2-(substituted 
alkylamino)-, 2-(heterocyclic substituted)- and 2-amino-2-deoxo-5-deazaalloxazines \{pyrimido[4,5- $b$ ] quinoline-4(3H)-one derivatives $(\mathbf{3 a}-\mathbf{m}, \mathbf{4} \mathbf{a}-\mathbf{g}$ and $\mathbf{5 a}, \mathbf{b})$ as represented in Scheme 1 . These derivatives (3a-m, $\mathbf{4} \mathbf{a}-\mathbf{g}$ and $\mathbf{5 a}, \mathbf{b})$ have higher aqueous solubility because of their polar side chain bearing different amino groups at position 2, which may be the predisposing factor for boosting their potency and selectivity.

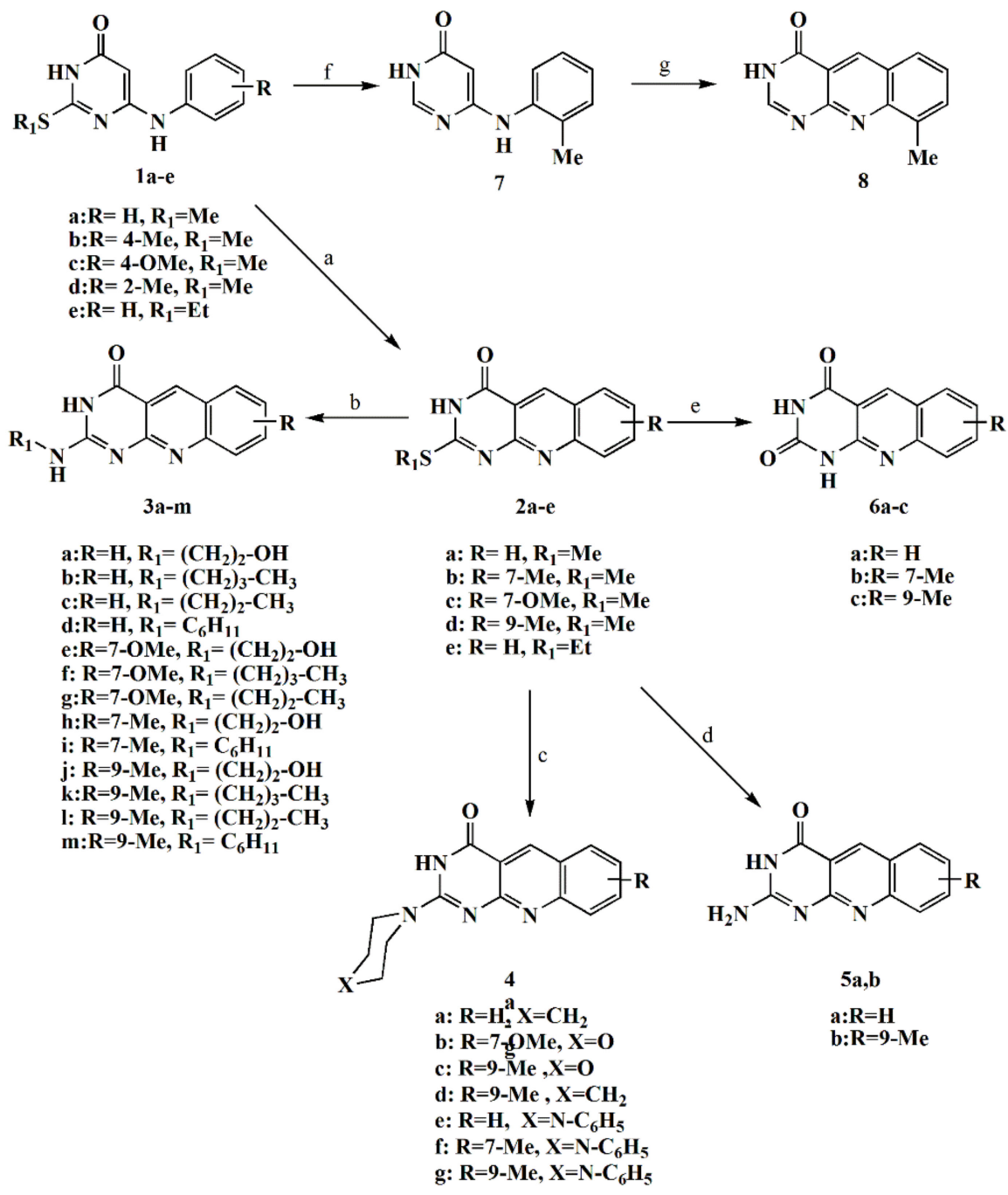

Scheme 1. General methods for the preparation of 2-deoxo-2-alkylthio-5-deazaalloxazines (2a-e), 2-(substituted alkyl amino)-2-deoxo-5-deazaalloxazines (3a-m), 2-(heterocyclic substituted)-2 -deoxo-5-deazaalloxazines (4a-g), 2-amino-2-deoxo-5-deazaalloxazines (5a,b), 2,4-dioxo-5-deazaalloxzines (6a-c), 2-deoxo-5-deazaalloxazine (8). Reagents and conditions: (a) DMF-POCl ${ }_{3}, 90{ }^{\circ} \mathrm{C}, 1-4 \mathrm{~h} ;(\mathbf{b}) \mathrm{R}_{1} \mathrm{NH}_{2}$, DMF, reflux 7-9 h; (c) $2^{\text {ry }}$ amine, DMF, reflux 24-30 h; (d) $\mathrm{CH}_{3} \mathrm{COONH}_{4}, 160-165{ }^{\circ} \mathrm{C}, 0.5-1.5 \mathrm{~h}$; (e) $5 \mathrm{M}$ $\mathrm{HCl}$, reflux, 15 h; (f) Raney Ni, absolute ethanol, 0.5 h; (g) DMF-POCl $3,90{ }^{\circ} \mathrm{C}, 2 \mathrm{~h}$.

2-(Substituted alkyl amino)-2-deoxo-5-deazaalloxazines (3a-m) were synthesized by heating under reflux the compounds 2-deoxo-2-alkylthio-5-deazaalloxazines (2) with an appropriate primary amine including ethanolamine, $n$-butylamine, $n$-propylamine, and/or cyclohexylamine for $7-9 \mathrm{~h}$. The products $(3 \mathbf{a}-\mathbf{m})$ were obtained as yellow needles in $60-88 \%$ yields. Moreover, a variety of substitutions namely, 2-piperidin-1-yl, 2-morpholin-4-yl and 2-piprazin-4-yl of 2-deoxo-5-deazaalloxazines (4a-g) were prepared by refluxing of the intermediate compounds (2) with an appropriate secondary amine including morpholine, piperidine, and/or $N$-phenylpiperazine in dimethylformamide (DMF) for $24-30 \mathrm{~h}$. All the products of $(\mathbf{4} \mathbf{a}-\mathbf{g})$ were afforded as needles with bright yellow color in 
$64-75 \%$ yields. Whereas, 2 -amino-2-deoxo-5-deazaalloxazines $(5 \mathbf{a}, \mathbf{b})$ were synthesized by fusion of 2-deoxo-2-alkylthio-5-deazaalloxazines (2) with ammonium acetate for $0.5-3 \mathrm{~h}$ at $160-165{ }^{\circ} \mathrm{C}$ to produce the corresponding 5 -deazaalloxazines $(5 \mathbf{a}, \mathbf{b})$ as yellow needles in $69-83 \%$ yields. The excess amines, in the above reactions involving treatment with volatile amines, were evaporated under vacuo. While, the high boiling point amines such as piperidine, morpholine and $N$-phenylpiperazine were separated from residue by treating with water or ethanol to get amine-free products.

Acidic hydrolysis of the intermediate 2-deoxo-2-alkylthio-5-deazaalloxazines (2) in $5 \mathrm{M}$ hydrochloric acid by heating under reflux for $10-15 \mathrm{~h}$ produces the corresponding 2,4-dioxo-5deazaalloxzines $(\mathbf{6 a}-\mathbf{c})$ as sharp yellow needles in $62-84 \%$ yields. Desulfurization of the alkyl mercapto substituent is often a critical step in heterocyclic synthesis, particularly in pyrimidine chemistry [27]. The most commonly used method of desulfurization is to reflux the target compound with an excess of Raney nickel (Mozingo conditions) [28]. According to Mozingo, R. et al., two courses for the reaction of sulfide may be postulated. In the first of these, the nickel is considered to function as a metal removing the sulfur in the Wurtz-type reaction, Figure 4a. Alternatively, in the presence of sufficient Raney nickel catalyst, to contain an excess of hydrogen, the reaction may take the course represented by Figure $4 \mathrm{~b}$.

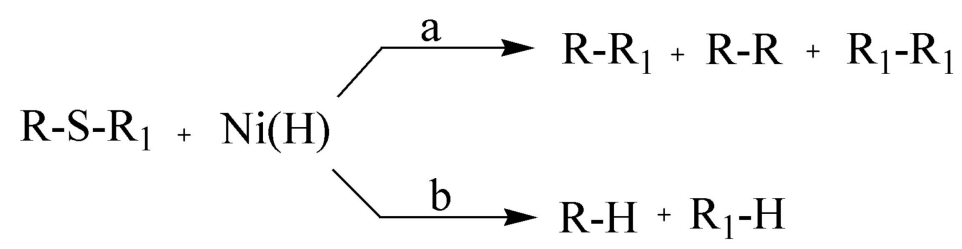

Figure 4. Desulfurization method under Mozingo conditions (a) and in the presence of sufficient Raney nickel catalyst (b).

In the desulfurization reaction under Mozingo conditions, using aliphatic and aromatic sulfides, disulfides, sulfoxides and sulfones with sufficient Raney nickel catalyst only the reaction (b) has been observed. That is, in case, the rupture of the C-S bond was accompanied by the formation of a new $\mathrm{C}-\mathrm{H}$ bond and a combination of the organic radicals did not occur. Other methods for the replacement of the mercapto group by hydrogen include oxidation with nitric acid or with hydrogen peroxide in acidic solution [27]. In this study, the 2-unsubstituted-2-deoxo-5-deazaalloxazines derivatives were prepared by dethiation approach of the corresponding 2-methylthio analogs. The required 6-(o-tolylamino) pyrimidin-4(3H)-one (7) was prepared by dethiation of 6-( $\mathrm{N}$-o-tolylamino)-2methylthiopyrimidin-4(3H)-one (1d) by using an excess of Raney nickel and heating under reflux in ethanol for $0.5 \mathrm{~h}$ to afford $70 \%$ yield. The dethiated 5-deazaalloxazine analog, namely, 9-methylpyrimido $[4,5-b]$ quinolin-4-ol (8), was synthesized according to the reported procedure [8] by the reaction of 6-(o-tolylamino) pyrimidin-4(3H)-one (7) with Vilsmier reagent $\left(\mathrm{DMF}-\mathrm{POCl}_{3}\right)$ at $90^{\circ} \mathrm{C}$ for $2 \mathrm{~h}$ to produce pale yellow needles in $80 \%$ yield, as represented in Scheme 1.

The UV/VIS, ${ }^{1} \mathrm{H}-\mathrm{NMR}$, mass spectra, IR and elemental analysis were applied to determine and identify the synthesized compounds. ${ }^{1} \mathrm{H}-\mathrm{NMR}$ spectra proved the intermediate compounds (1a-d) by the presence of a proton resonance as a singlet signal at 5-position at 5.04-5.51 ppm, as reported [8]. The cyclized 2-deoxo-2-alkylthio-5-deazaalloxazines ( $\mathbf{2} \mathbf{b}-\mathbf{e})$ exhibited a significant singlet signal because of the proton at $\mathrm{C} 5$ in the lower field at $9.01-9.18 \mathrm{ppm}$. Also, compounds $(\mathbf{2} \mathbf{b}-\mathbf{d})$ showed a slight downfield shift of their ${ }^{1} \mathrm{H}-\mathrm{NMR}$ singlet signal of 2-SMe moieties being at 2.56-2.85 ppm owing to the newly cyclized conjugated tricyclic pyrimido[4,5- $b$ ] quinolin-4(3H)-one ring in comparison with the of uncyclized analog. Additionally, 3-NH singlet signals at ${ }^{1} \mathrm{H}-\mathrm{NMR}$ spectra were detected at 11.78-12.68 ppm for the 2-SMe cyclized derivatives $(\mathbf{2} \mathbf{b}-\mathbf{d})$, whereas, ${ }^{1} \mathrm{H}-\mathrm{NMR}$ singlet signal of 3-NH for compound 2e exhibited at an upfield shift of $9.43 \mathrm{ppm}$. This is because of the 2-ethylthio group has higher electron donating properties than that of the 2-methylthio group (see Supplementary Materials).

2-(Substituted alkyl amino)-2-deoxo-5-deazaalloxazines (3a-m), 2-(heterocyclic substituted)-2deoxo- 5-deazalloxazines (4a-g) and 2-amino-2-deoxo- 5-deazaalloxazine derivatives $(5 \mathbf{a}, \mathbf{b})$ were characterized by vanishing the 2 -methylthio group singlet signal of their precursors $(\mathbf{2 a}-\mathbf{e})$. This is 
concurrent with the appearance of a singlet signal of the 2-NH at $\delta_{\mathrm{H}}: 6.52-6.90 \mathrm{ppm}$ for compounds $\mathbf{3 a}-\mathbf{c}, \mathbf{e}-\mathbf{h}, \mathbf{j}-\mathbf{l}$. While the $2-\mathrm{NH}$ singlet signal of the 2-(cyclohexyl amino) analogs $(\mathbf{3 d}, \mathbf{i}, \mathbf{m})$ are located at upfield region $\delta_{\mathrm{H}}: 3.93-3.95 \mathrm{ppm}$ owing to the positive inductive effect of cyclohexyl moiety. 2-(Piperiden-1-yl)-2-deoxo-5-deazalloxazines $(4 \mathbf{a}, \mathbf{d})$ are elucidated by their $6 \mathrm{H}$ multiplets at $\delta_{\mathrm{H}}: 1.50-1.66 \mathrm{ppm}$ and $4 \mathrm{H}$ multiplets at $\delta_{\mathrm{H}}: 3.73-3.82 \mathrm{ppm}$ for the piperidinyl moiety. 2-(Morpholin-4 -yl)-2-deoxo- 5-deazalloxazines $(4 \mathbf{b}, \mathbf{c})$ are elucidated by their twin $4 \mathrm{H}$ multiplets at $\delta_{\mathrm{H}}: 3.22-3.29$ and 3.70-3.86 ppm for the morpholinyl moiety. Similarly, 2-(4-phenylpiperazin-1-yl)-pyrimido[4,5-b] quinoline-4-ol derivatives $(4 \mathbf{e}-\mathbf{g})$ are identified by their piperazinyl two $4 \mathrm{H}$ multiplets at $\delta_{\mathrm{H}}: 3.03-3.34$ and 3.93-3.99 ppm.

Interestingly, the phenomenon of amide-imidol tautomerism was noticed for the ${ }^{1} \mathrm{H}-\mathrm{NMR}$ spectra for 2-deoxo-2-(4-phenylpiperazin-1-yl)-5-deazaalloaxazines (4e-g). The imidol tautomer predominates in ${ }^{1} \mathrm{H}-\mathrm{NMR}$ (DMSO- $\mathrm{d}_{6}$ at $25^{\circ} \mathrm{C}$ ), Figure 5 . The characteristic signal of the $4-\mathrm{OH}$ proton was detected at $\delta_{\mathrm{H}}: 3.44-4.49 \mathrm{ppm}$ in the ${ }^{1} \mathrm{H}-\mathrm{NMR}$ spectra concurrent disappearance of the singlet signal of the 3-NH proton. This also confirmed by the disappearance of 3-NH and $\mathrm{C}=\mathrm{O}$ bands in the IR spectrum and displaced by the $\mathrm{OH}$ stretching band at $3421-3434 \mathrm{~cm}^{-1}$.

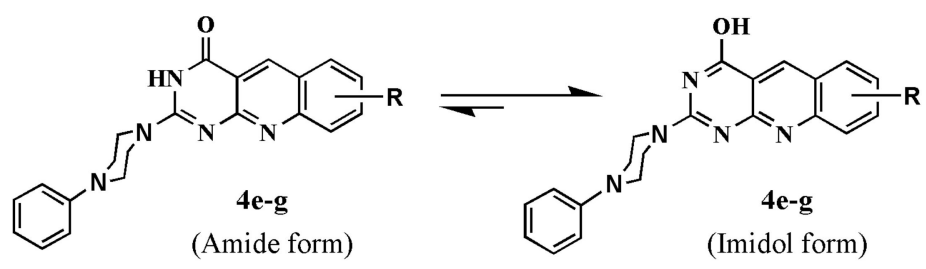

Figure 5. The amide-iminol tautomerism for compounds 2-deoxo-2-(4-phenylpiperazin-1-yl)-5deazaalloxazines $(4 \mathbf{e}-\mathbf{g})$.

Compounds $(5 \mathbf{a}, \mathbf{b})$ are characterized by appearance of $\mathrm{D}_{2} \mathrm{O}$ exchangeable broad singlet signals at $\delta_{\mathrm{H}}: 6.72$ and $6.74 \mathrm{ppm}$ belong to exocyclic $2-\mathrm{NH}_{2}$ and broad singlet signals of 3- $\mathrm{NH}$ at $\delta_{\mathrm{H}}: 10.81$ and 11.18 ppm, respectively.

The ${ }^{1} \mathrm{H}-\mathrm{NMR}$ spectra of 2,4-dioxo-5-deazaalloxzines (6a-c), were elucidated by their two characteristic $\mathrm{D}_{2} \mathrm{O}$ exchangeable broad singlet signals at $\delta_{\mathrm{H}}$ : 10.93-11.49 and 11.34-11.76 ppm which are corresponding to $1-\mathrm{NH}$ and 3-NH, respectively. Two strong IR peaks at $v_{\mathrm{cm}}{ }^{-1} 1712-1703$ and $1625-1615 \mathrm{~cm}^{-1}$ boosted their structural elucidation.

In general, the UV spectra of 2-deoxo-2-alkylthio-5-deazalloxazines (2a-e) showed longer wavelength than those of compounds $\mathbf{3 a}-\mathbf{m}, \mathbf{4 a}-\mathbf{g}, \mathbf{5 a}, \mathbf{b}, \mathbf{6 a}-\mathbf{c}$ and $\mathbf{8}$ as shown in Figure 6. This redshift (bathochromic shift) is attributed to the easier polarizability of the S-atom in 2-alkylthio analogs (2a-e) [29]. The UV/VIS absorption spectra of compounds ( $4 \mathbf{b}-\mathbf{e})$ exhibited three absorption maxima at 230-254, 284-287 and 362-401 nm with one absorption shoulder at 266-279 $\mathrm{nm}$. While, the UV/VIS absorption spectra of 7-methoxy2-(substituted alkyl amino)-2-deoxo-5-deazaalloxazines (3f,g) show four absorption maxima at 224-230, 267-277, 327-370, 394-401 nm without any absorption shoulder. While the other 2-(substituted alkyl amino)-2-deoxo-5-deazaalloxazines (3a-e, h-m), 2-(heterocyclic substituted)-2-deoxo-5-deazaalloxazines (4a-g) and 2-amino-2-deoxo-5-deazaalloxazines (5a,b) show three absorption maxima together with an absorption shoulder as shown in Figure 6. 


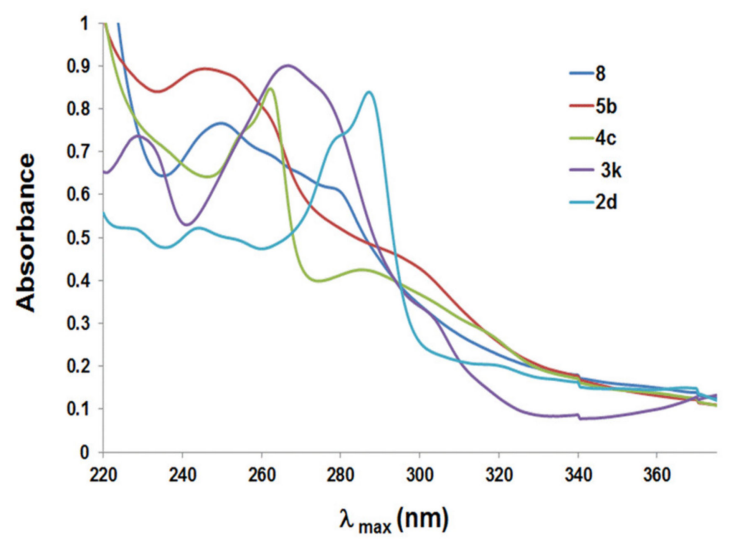

Figure 6. UV-VIS spectra of 9-methyl-2-methylthio-5-deazaalloxazine (2d), 2-butylamino-9-methyl5-deazaalloxazine (3k), 9-methyl-2-(morpholin-4-yl)-5-deazaalloxazine (4c), 2-amino-9-methyl5-deazaalloxazine (5b) and 2-deoxo-5-deazaalloxazine (8).

Based on the reported electron ionization (EI) fragmentation of $\mathrm{N}$ (5)-oxides of alloxazine and isoalloxazine derivatives [30] the principal mass spectral fragmentation routes of compounds 2,4-dioxo-5-deazaalloxzines $(\mathbf{6 a}-\mathbf{c})$ were proposed as shown in Scheme 2 . This includes ions $b$ formed by a retro-Diels-Alder (RDA) reaction by the ejection of an $\mathrm{HNCO}$ moiety from the tautomeric pyrimidine ring of (a) ions. The next fragmentation involved the elimination of $\mathrm{CO}$ or $\mathrm{CO}$ and $\mathrm{H}^{-}$species for the formation of odd-electron and even-electron ions (c) and (d), respectively. Consecutive ejections of $\mathrm{HCN}$ molecules from fragment $\mathbf{c}$, with or without elimination of the $\mathrm{H}$ radical, result in the liberation of fragments $\mathbf{e}, \mathbf{f}, \mathbf{g}$ and $\mathbf{h}$, Table 1 .

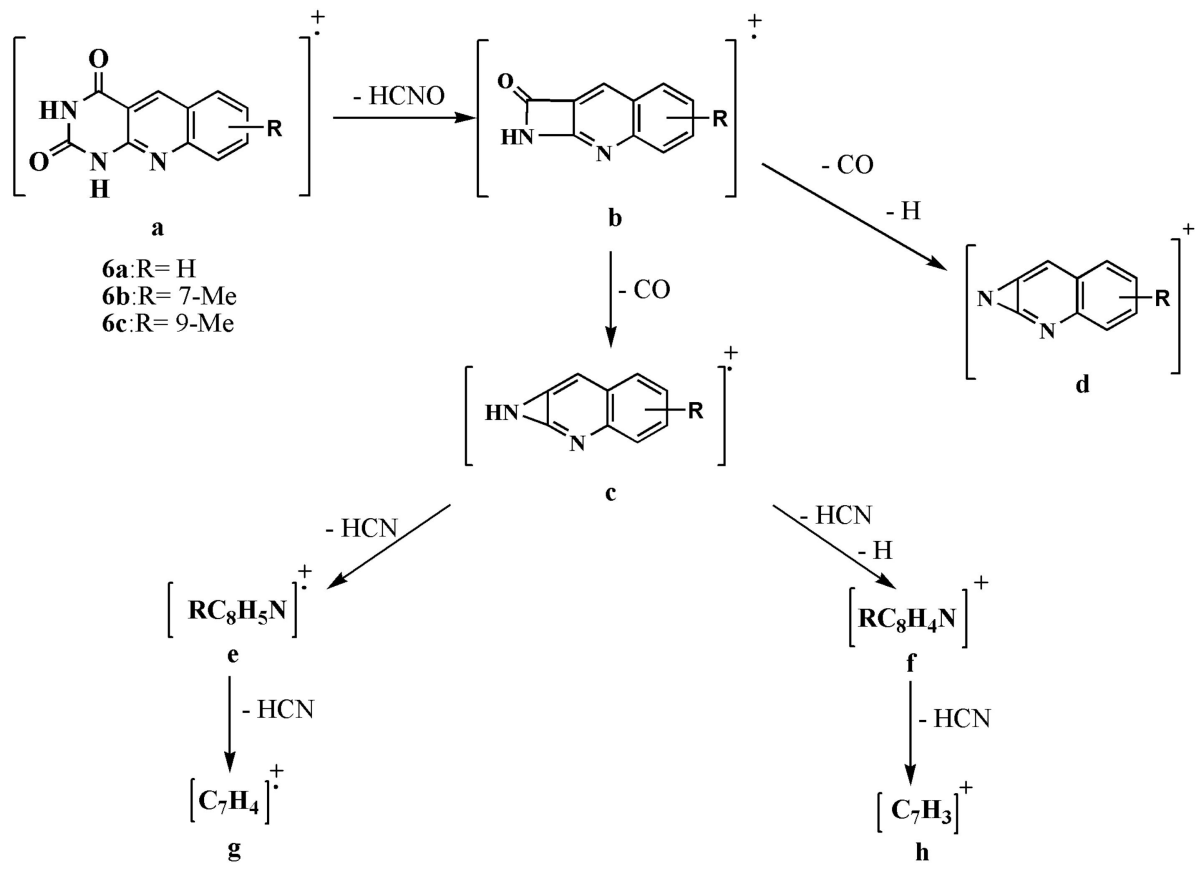

Scheme 2. Proposed principal of Electron Ionization Mass Spectrometry (EI-MS) fragmentation routes of compounds $(6 \mathbf{a}-\mathbf{c})$. 
Table 1. Elemental composition and relative abundance of the ions in the spectra of compounds $6 a-c$ according to the mass spectral data.

\begin{tabular}{|c|c|c|c|c|c|}
\hline \multirow{2}{*}{ Ions } & \multirow{2}{*}{$m / z$} & \multirow{2}{*}{$\begin{array}{c}\text { Elemental } \\
\text { Composition }\end{array}$} & \multicolumn{3}{|c|}{$\%$ Relative Abundance } \\
\hline & & & $6 a$ & $6 b$ & $6 c$ \\
\hline \multirow{2}{*}{$\stackrel{\mathrm{a}}{\left[\mathrm{M}^{+}\right]}$} & 213 & $\mathrm{C}_{11} \mathrm{H}_{7} \mathrm{~N}_{3} \mathrm{O}_{2}$ & 83 & - & - \\
\hline & 227 & $\mathrm{C}_{12} \mathrm{H}_{9} \mathrm{~N}_{3} \mathrm{O}_{2}$ & - & 100 & 39 \\
\hline \multirow{2}{*}{$\mathrm{b}$} & 170 & $\mathrm{C}_{10} \mathrm{H}_{6} \mathrm{~N}_{2} \mathrm{O}$ & 35 & - & - \\
\hline & 184 & $\mathrm{C}_{11} \mathrm{H}_{8} \mathrm{~N}_{2} \mathrm{O}$ & - & 34 & - \\
\hline \multirow{2}{*}{ c } & 142 & $\mathrm{C}_{9} \mathrm{H}_{6} \mathrm{~N}_{2}$ & 20 & - & - \\
\hline & 156 & $\mathrm{C}_{10} \mathrm{H}_{8} \mathrm{~N}_{2}$ & - & 26 & - \\
\hline \multirow{2}{*}{$\mathrm{d}$} & 141 & $\mathrm{C}_{9} \mathrm{H}_{5} \mathrm{~N}_{2}$ & 15 & - & - \\
\hline & 155 & $\mathrm{C}_{10} \mathrm{H}_{7} \mathrm{~N}_{2}$ & - & 23 & 36 \\
\hline \multirow{2}{*}{ e } & 115 & $\mathrm{C}_{8} \mathrm{H}_{5} \mathrm{~N}$ & 80 & - & - \\
\hline & 129 & $\mathrm{C}_{9} \mathrm{H}_{7} \mathrm{~N}$ & - & 21 & 50 \\
\hline \multirow{2}{*}{$\mathrm{f}$} & 114 & $\mathrm{C}_{8} \mathrm{H}_{4} \mathrm{~N}$ & 100 & - & - \\
\hline & 128 & $\mathrm{C}_{9} \mathrm{H}_{6} \mathrm{~N}$ & - & 30 & 100 \\
\hline \multirow{2}{*}{$\mathrm{g}$} & 88 & $\mathrm{C}_{7} \mathrm{H}_{4}$ & 36 & - & - \\
\hline & 102 & $\mathrm{C}_{8} \mathrm{H}_{6}$ & - & 21 & 32 \\
\hline \multirow{2}{*}{$\mathrm{h}$} & 87 & $\mathrm{C}_{7} \mathrm{H}_{3}$ & 28 & - & - \\
\hline & 101 & $\mathrm{C}_{8} \mathrm{H}_{5}$ & - & 17 & 44 \\
\hline
\end{tabular}

\subsection{Antiproliferative MTT Assay}

The modified 3-(4,5-dimethylthiazol-2-yl)-2,5-diphenyltetrazolium bromide (MTT) assay [31] developed by M. Tim [32] was used to determine the in vitro antiproliferative activities of the test 5-deazaalloxazine compounds against human tumor cell lines, namely, T-cell acute lymphoblastoid leukemia cell line (CCRF-HSB-2) and oral epidermoid carcinoma cell line (KB), using cytosine arabinoside (Ara-C) as a positive control. Another two cells namely: Michigan Cancer Foundation-7 cell line (MCF-7) and cervical cancer cell line (HeLa) were utilized relative to the $\%$ viability of $1 \%$ DMSO as a negative untreated control.

As can be noticed in Table 2, 2-(cyclohexylamino)-2-deoxo-5-deazaalloxazines ( $\mathbf{3} \mathbf{d}$, $\mathbf{i}$ and $\mathbf{m}$ ) revealed reasonable antitumor activities; which were the highest among their analogs; against both of CCRF-HSB-2 and KB cell lines of $\mathrm{IC}_{50}$ in the range of $(6.71-14.91 \mu \mathrm{M})$ and $(6.35-17.47 \mu \mathrm{M})$, respectively, compared to the positive control Ara-C. It is noticed that 2-aminopyrimido[4,5- $b$ ] quinolin- $4(3 H)$-one (5a) exhibited high selective antiproliferative activity against KB cell lines over CCRF-HSB-2 cell lines. Its $\mathrm{IC}_{50}$ against $\mathrm{KB}$ tumor cell lines was $1.46 \mu \mathrm{M}$, whereas, its $\mathrm{IC}_{50}$ against CCRF-HSB-2 cell lines was $>100 \mu \mathrm{M}$.

On the other hand, 2-(2-hydroxyethylamino)-7-methyl-pyrimido[4,5-b] quinolin-4(3H)-one (3h) revealed a significant antitumor activity; which was the highest among their analogs; against both of MCF-7 and HeLa tumor cell lines of $\mathrm{IC}_{50} 0.17 \mu \mathrm{M}$ and $2.00 \mu \mathrm{M}$ as shown in Table 2, respectively. It is noticed that compounds $(\mathbf{2 b}, \mathbf{2 c}, \mathbf{3 e}, \mathbf{3 f}, \mathbf{3 g}, \mathbf{4 b}, \mathbf{6 a}$ and $\mathbf{6 c})$ revealed high selective antiproliferative activity against MCF-7 tumor cell lines over HeLa tumor cell lines. Their $\mathrm{IC}_{50}$ against MCF-7 tumor cell lines were $0.22-2.17 \mu \mathrm{M}$, whereas, their $\mathrm{IC}_{50}$ against HeLa tumor cell lines were $>100 \mu \mathrm{M}$, respectively. Contrary, compounds (3c, 31, $\mathbf{6 b}$ and $\mathbf{8}$ ) showed high selectivity against HeLa tumor cell lines over MCF-7 tumor cell lines. Their $\mathrm{IC}_{50}$ against HeLa tumor cell lines were $0.57,0.13,1.39$ and $0.33 \mu \mathrm{M}$, whereas, their $\mathrm{IC}_{50}$ against MCF-7 tumor cell lines were $8.49,>100,29.45$ and $18.22 \mu \mathrm{M}$, respectively. 
Table 2. The inhibitory activities of the synthesized 5-deazaalloxazine derivatives against CCRF-HSB-2, KB, MCF-7 and HeLa tumor cell lines.

\begin{tabular}{cccccc}
\hline \multicolumn{5}{c}{ Inhibitory Activity Against Tumor Cell Lines $\left.\left[\mathbf{I C}_{\mathbf{5 0}} \boldsymbol{\mu M}\right)\right]$} & \\
\hline Compd & CCRF-HSB-2 & KB & Compd & MCF-7 & HeLa \\
\hline $\mathbf{2 b}$ & 23.66 & 26.73 & $\mathbf{2 b}$ & 1.79 & $>100$ \\
$\mathbf{2 c}$ & 35.56 & 30.44 & $\mathbf{2 c}$ & 1.24 & $>100$ \\
$\mathbf{2 d}$ & $>100$ & $>100$ & $\mathbf{2 d}$ & 24.72 & 3.40 \\
$\mathbf{3 a}$ & 47.21 & 35.47 & $\mathbf{2 e}$ & $>100$ & $>100$ \\
$\mathbf{3 d}$ & 14.91 & 6.93 & $\mathbf{3 b}$ & 4.40 & 16.67 \\
$\mathbf{3 i}$ & 6.71 & 6.35 & $\mathbf{3 c}$ & 8.49 & 0.57 \\
$\mathbf{3 j}$ & $>100$ & 24.9 & $\mathbf{3 e}$ & 1.10 & $>100$ \\
$\mathbf{3} \mathbf{3}$ & $>100$ & 11.62 & $\mathbf{3 f}$ & 1.74 & $>100$ \\
$\mathbf{3 m}$ & 9.17 & 17.47 & $\mathbf{3 g}$ & 0.22 & $>100$ \\
$\mathbf{4 a}$ & 49.58 & 36.74 & $\mathbf{3 h}$ & $\mathbf{0 . 1 7}$ & 2.00 \\
$\mathbf{4} \mathbf{c}$ & 39.14 & 23.79 & $\mathbf{3 1}$ & $>100$ & 0.13 \\
$\mathbf{4 d}$ & 19.41 & 26.01 & $\mathbf{4 b}$ & 1.25 & $>100$ \\
$\mathbf{4 e}$ & 69.38 & 28.53 & $\mathbf{6 a}$ & 2.17 & $>100$ \\
$\mathbf{4 f}$ & 50.61 & 60.30 & $\mathbf{6 b}$ & 29.45 & 1.39 \\
$\mathbf{4 g}$ & $>100$ & 23.28 & $\mathbf{6 c}$ & 2.10 & $>100$ \\
$\mathbf{5 a}$ & $>100$ & 1.46 & $\mathbf{8}$ & 18.22 & 0.33 \\
$\mathbf{5 b}$ & 44.64 & 73.81 & $5-F U$ & 5.15 & 7.76 \\
Ara-c & 0.14 & 0.26 & & & \\
\hline
\end{tabular}

Interestingly, the $\mathrm{IC}_{50}$ of 2-hydroxyethylamino derivative (3h) was improved ten times from the $\mathrm{IC}_{50}$ of its starting compound 2- methylthio derivatives (2b) being of $0.17 \mu \mathrm{M}$ and $1.79 \mu \mathrm{M}$, respectively, against MCF-7 tumor cell line. This suggested that the polar side chain at position 2 enhances the solubility of 5- deazaalloxazine derivatives and could be essential for their antitumor activity. The MTT assay result of Compound $3 \mathrm{~h}$ revealed the highest $\mathrm{IC}_{50}$ against MCF- 7 breast cancer cell line and HeLa cervical cancer cell line ( $\mathrm{IC}_{50} 0.17 \mu \mathrm{M}$ and $2.00 \mu \mathrm{M}$ ) in comparison to other compounds, which is considered as a new lead for our derivatives and motivated us for further investigation. Nonetheless, this result is less consistent with its binding affinity into c-Kit PTK $\left(\Delta G_{\mathrm{b}}:-11.07 \mathrm{kcal} / \mathrm{mol}\right)$ and room mean square deviation (RMSD) of $6.13 \AA$

\subsection{In Vitro Protein Kinase Assay}

Kinase profiling intends to detect the selectivity of a lead compound against a comprehensive panel of kinases by determining its extent of phosphorylation or dephosphorylation. The protein kinase profile of compound (3h) against a large group of protein kinases was evaluated using the 33P- $\gamma$ ATP radiometric assay method at one concentration $(10 \mu \mathrm{M})$ in a single measurement by utilizing the methodology of the standardized assay, summarized in the experimental part. The PK profiling assay was performed by KINEXUS Bioinformatics Corporation, Canada. Two reference kinase inhibitors on the phosphotransferase activity were used including Imatinib (BCR-ABL tyrosine kinase inhibitor) and lapatinib (EGFR and HER2 dual selective tyrosine kinase inhibitor). In this study, the results are reported in Figures 7 and 8 as the percentage change in the activation and inhibition in comparison with the control. The negative (-) values indicate the inhibition activity of target by compound, while the positive (+) values indicate the activation activity of the target. The percentages that more than $25 \%$ are counted to be a promising result. 


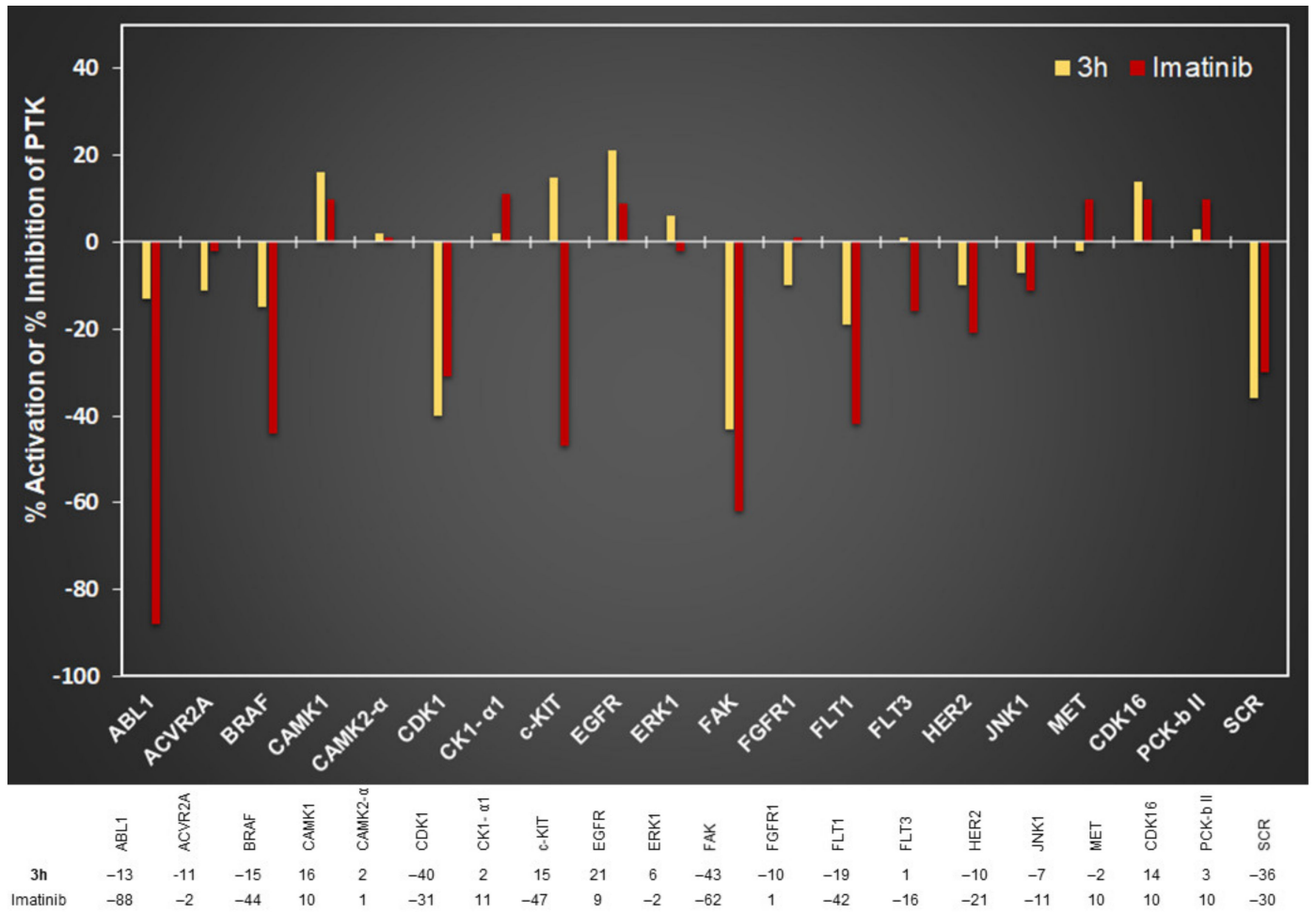

Figure 7. Protein kinase profiling for compound (3h) at $10 \mu \mathrm{M}$ concentration against 20 PKs compared to imatinib.

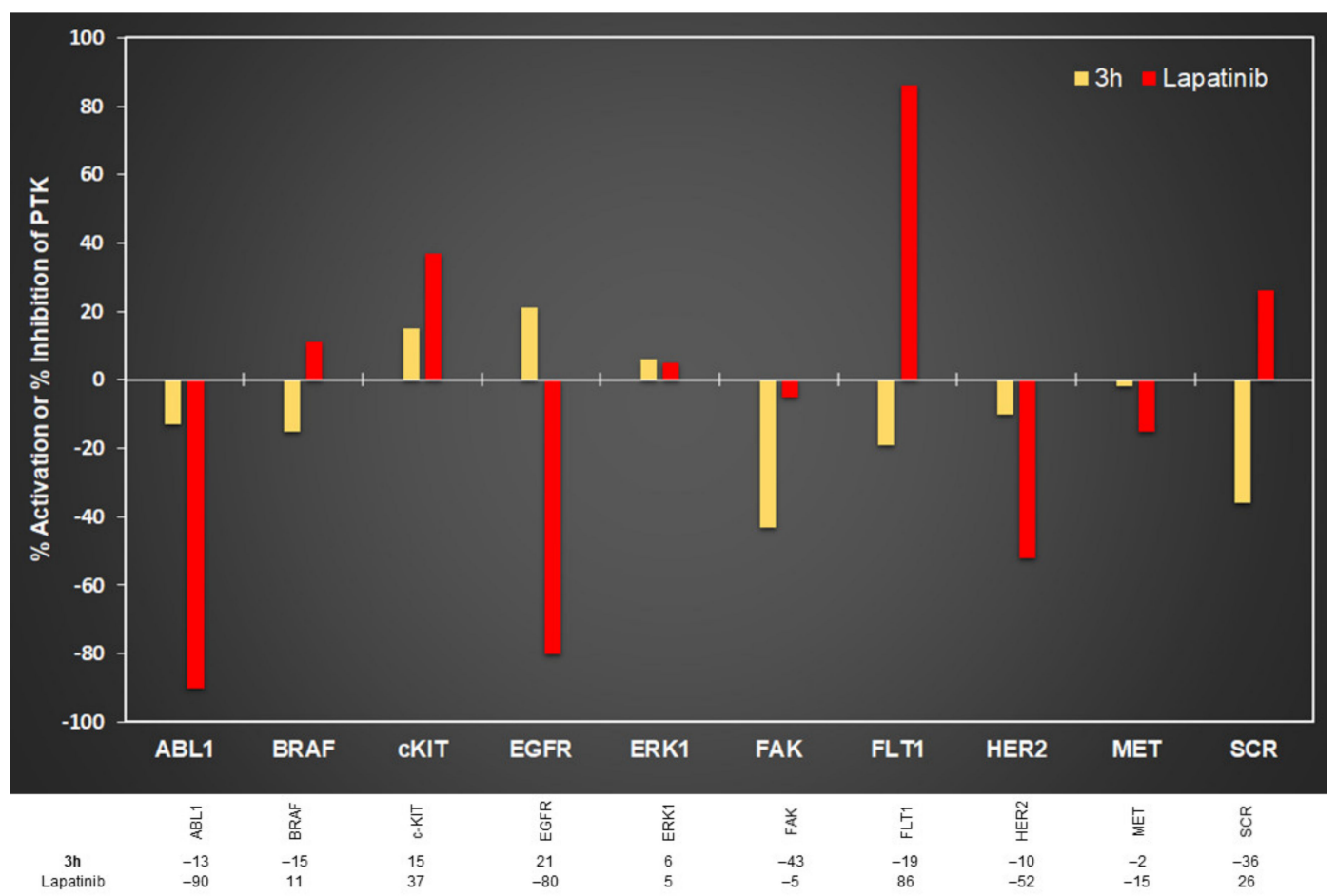

Figure 8. Protein kinase profiling for compound (3h) at $10 \mu \mathrm{M}$ concentration against 10 PKs compared to lapatinib.

Three out of twenty kinases tested by compound (3h) exhibited reasonable inhibition scores ranging from $-36 \%$ to $-43 \%$ including FAK $(-43 \%)$, CDK1/Cyclin A1 $(-40 \%)$ and SCR $(-36 \%)$ compared to the reference compound Imatinib, which showed significant inhibitory effects with FAK $(-62 \%)$, 
CDK1/Cyclin A1 (-31\%), SCR (-30\%), respectively. Notably, seven out of twenty tested kinases were markedly affected by Imatinib including ABL1, BRAF, CDK1, c-Kit, FAK, FLT1 and SCR kinases with inhibition $-88 \%,-44 \%,-31 \%,-47 \%,-62 \%,-42 \%$ and $-30 \%$, respectively.

Another reference compound lapatinib was used as a selective dual kinase inhibitor, which interrupts the HER2 and EGFR pathways. Comparing the 5-deazaalloxazine analog (3h) with lapatinib, the compound (3h) expressed a moderate inhibition with FAK (-43\%), while lapatinib showed slight inhibition ( $-5 \%)$. Moreover, the compound $(3 \mathrm{~h})$ revealed inhibition with BRAF (-15\%) and FLT1 (-19\%), whereas lapatinib exhibited a slightly to strongly activation with BRAF (11) and FLT1 (86\%), as showed in Figure 8. Notably, three out of ten tested kinases were markedly affected by lapatinib, including ABL1, EGFR and HER2 kinases with inhibition $-90 \%,-80 \%,-52 \%$, respectively. However, lapatinib revealed a moderate to high activation with c-Kit and FLT1 kinases being of 37\% to $86 \%$ that can boost the deregulation of cellular pathways in cancer patients. Generally, the unregulated activity of the c-Kit kinase is connected to the cancer pathogenesis in human, whereas c-Kit kinase activity is controlled by a tight regulation in the normal cells [33]. Profiling result of compound $3 \mathrm{~h}$ revealed slight activation of the c-Kit kinase by $15 \%$, as presented in Figure 8 . Interestingly, the binding affinity of this compound has a slight affinity into the binding site of c-Kit PTK ( $\Delta G_{\mathrm{b}}$ being of $-11.07 \mathrm{kcal} / \mathrm{mol}$ ) and RMSD of $6.13 \AA$. This docking result could elucidate the activation result of compound $3 \mathrm{~h}$ against c-kit kinase.

Overall, this profiling study revealed that the 2-hydroxyethylamino-5-deazaalloxazine analog (3h) has antiproliferative activity by causing multi-target kinases inhibition, including FAK (-43\%), CDK1/Cyclin A1 (-40\%) and SCR (-36\%). This compound (3h) has a high solubility in aqueous solutions because of the polar side chain of 2-hydroxyethylamine at position 2, which could be responsible for its fundamental potency (36-43\%), which promoted us for further lead optimization studies [34].

\subsection{Annexin V PI/FITC Apoptosis Assay}

According to reported research $[35,36]$ deazaalloxazine analogs expressed a potential capacity of activating the tumor suppressor protein p53 causing a subsequent cell cycle arresting and apoptosis. Annexin V Fluorescein Isothiocyanate/Propidium Iodide (FITC/PI) apoptosis assay was conducted for testing whether different concentrations of compound ( $3 \mathrm{~h}$ ) have apoptosis-inducing activity. The treated and untreated (control) were analyzed with flow cytometry (BC, FC500) after labeling by annexin-V FITC/PI.

Compound ( $3 \mathbf{h})$ was selected for apoptosis assay regarding its potential inhibitory effect on cell proliferation and multiple kinases, as shown in Table 2, Figures 7 and 8, respectively. Compound (3h) induced early and late apoptosis to MCF-7 cells in a dose-dependent pattern. The lowest concentration $(1.0 \mu \mathrm{M})$ of the compound ( $3 \mathrm{~h})$ showed $56 \%$ increased late apoptosis compared to the control. Raising the treatment compound $(3 \mathrm{~h})$ dose to 5 then $10 \mu \mathrm{M}$ resulted in a potential increase in both early and late apoptosis. The highest treatment concentration $(10 \mu \mathrm{M})$ produced $33 \%$ and $140 \%$ increase in early and late apoptosis compared to the control, respectively, as showed in Figure 9. Meanwhile, gathering the percentage change in early and late apoptosis between the treatment doses reveals that the most significant shift associated with the second concentration $(5 \mu \mathrm{M})$. Taken together suggests that the highest overall apoptotic effect of compound ( $3 \mathrm{~h})$ was at a dose of $(5 \mu \mathrm{M})$. On the other hand, MTT assay identified the $\mathrm{IC}_{50}$ of compound ( $\left.3 \mathrm{~h}\right)$ as $0.17 \mu \mathrm{M}$ against MCF-7 tumor cell line. MTT assay indicates the percentage of surviving cells compared to control and cannot recognize the mechanism by which the population of the treated cells was decreased [37]. Therefore, different compounds may generally express their antitumor effects by inhibiting different characteristic cellular functions and molecular pathways of cancer without directly inducing apoptosis. Additionally, the PK profiling study of compound $(\mathbf{3 h})$ demonstrates that this compound has antiproliferative activity by inhibition of FAK $(-43 \%)$, CDK1/Cyclin A1 (-40\%) and SCR (-36\%). Herein, it can be suggested that the compound (3h) revealed antitumor activity by inhibiting the proliferation and causing apoptosis of the cancer cells. 


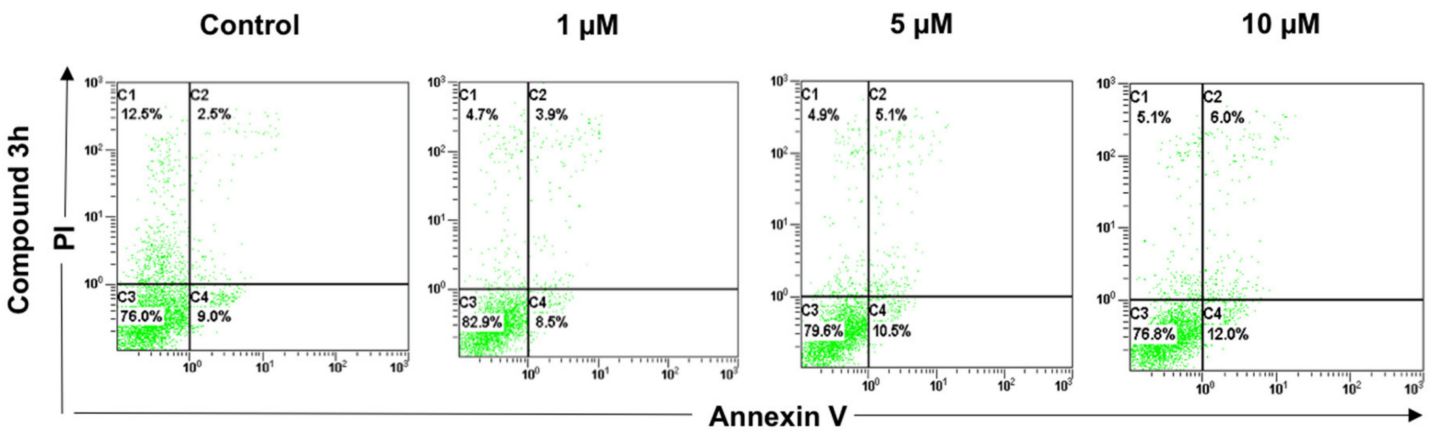

Figure 9. Apoptosis assay for compound $3 \mathrm{~h}$ with different concentrations. $\mathrm{X}$-axis: annexin $\mathrm{V}$ and Y-axis: PI. live cells (PI-/V-): C3; early apoptotic cells (PI-/V+): C4; late apoptotic cells (PI+/V+): C2; necrotic cells $(\mathrm{PI}+\mathrm{V}-)$ : $\mathrm{C} 1$.

\subsection{Structure-Activity Relationship (SAR)}

The studies of the structure-activity relationship (SAR) exhibited that the greatest antitumor activities were obtained with the structural features of 5-deazaalloxazin skeleton; the presence of ethanolamine, amino group substituent at C-2 position with unsubstituted quinoline nucleus or substituted by 7-Me revealed good antitumor activity as shown for compounds $3 \mathbf{h}$ and $\mathbf{5 a}$. Additionally, unsubstituted quinoline scaffold or substituted by 7-OMe group, 7-Me group or 9-Me group with thiomethyl, ethanolamine, butylamine, propylamine, morpholine or oxo group at $\mathrm{C}-2$ position show high selective antiproliferative activity against MCF-7 tumor cell lines as shown for compounds $\mathbf{2 b}, \mathbf{c}$, $3 e-g, 4 b, 6 a$ and $\mathbf{6 c}$. Moreover, unsubstituted quinoline scaffold or substituted by a 7-Me group or 9-Me group with cyclohexyl, propylamino, oxo group or without substitution at C-2 position show high selective antiproliferative activity against HeLa tumor cell lines as shown for compounds $\mathbf{2 c}$, $\mathbf{3} \mathbf{i}$, $6 \mathrm{~b}$ and 8 .

\subsection{Molecular Docking Study}

The AutoDock binding affinities of various 5-deazaalloxizine and 5-deazaflavin analogs for their potential protein tyrosine inhibitory activities have been investigated [8]. Herein, the molecular docking study was conducted using AutoDock 4.2 [38] by docking of synthesized derivatives into the c-Kit receptor PTK: platelet-derived growth factor receptor (PDGFR, c-kit; PDB code: 1t46) and co-crystallized with the c-kit PTK inhibitor (STI571).

The selection criteria used for molecular docking are listed as (1) full structure of the kinase domain of the retrieved protein from PDB structures, (2) high quality of the protein structure in this study the quality of chai A used is $83 \%$, (3) minimum resolution to ensure high quantity of the gathered data from the used kinase (1.60 ̊ for PDB: 1t46), (4) Using a kinase model co-crystallized with inhibitor (Imatinib, Gleevec or STI-571) to be used for validation of the accuracy of the docking algorithm of the software (AutoDock 4.2) and (5) to ensure removal of the native co-crystallized ligand, water molecules and cofactor (if available) before docking. Docking accuracy will be verified if the bound inhibitor (STI) is docked within RMSD $\leq 2.0 \AA$ from the natively co-crystallized pose. [39]. In addition, the docked compounds should reveal binding free energies $\left(\Delta G_{\mathrm{b}}\right)$ comparable to the native ligand and display a large number of hydrogen bonds with the most relevant amino acids (E640, T670, C673 and D810) involved in the inhibitor interaction into c-kit PTK (1t46).

\subsubsection{AutoDock Validation}

The docking accuracy of AutoDock had been validated by docking the native cocrystallized ligand (STI) into its binding site of PTK (PDB: 1t46) to examine the similarity between the docked conformation and the original ligand [39]. The original ligand (Imatinib, Gleevec or STI-571) showed four hydrogen bonds with the essential amino acids of PTK: E640, T670, C673 and D810 (Figure 10). 
The docked STI ligand appeared overlapped on the original STI ligand within RMSD being of $0.17 \AA$. Therefore, AutoDock validation was verified to allow further docking of the designed analogs [40]. These results similarly emulate the experimental results, revealing a successful docking protocol and confirming the accuracy of the GOLD docking program for further docking of the designed hits.

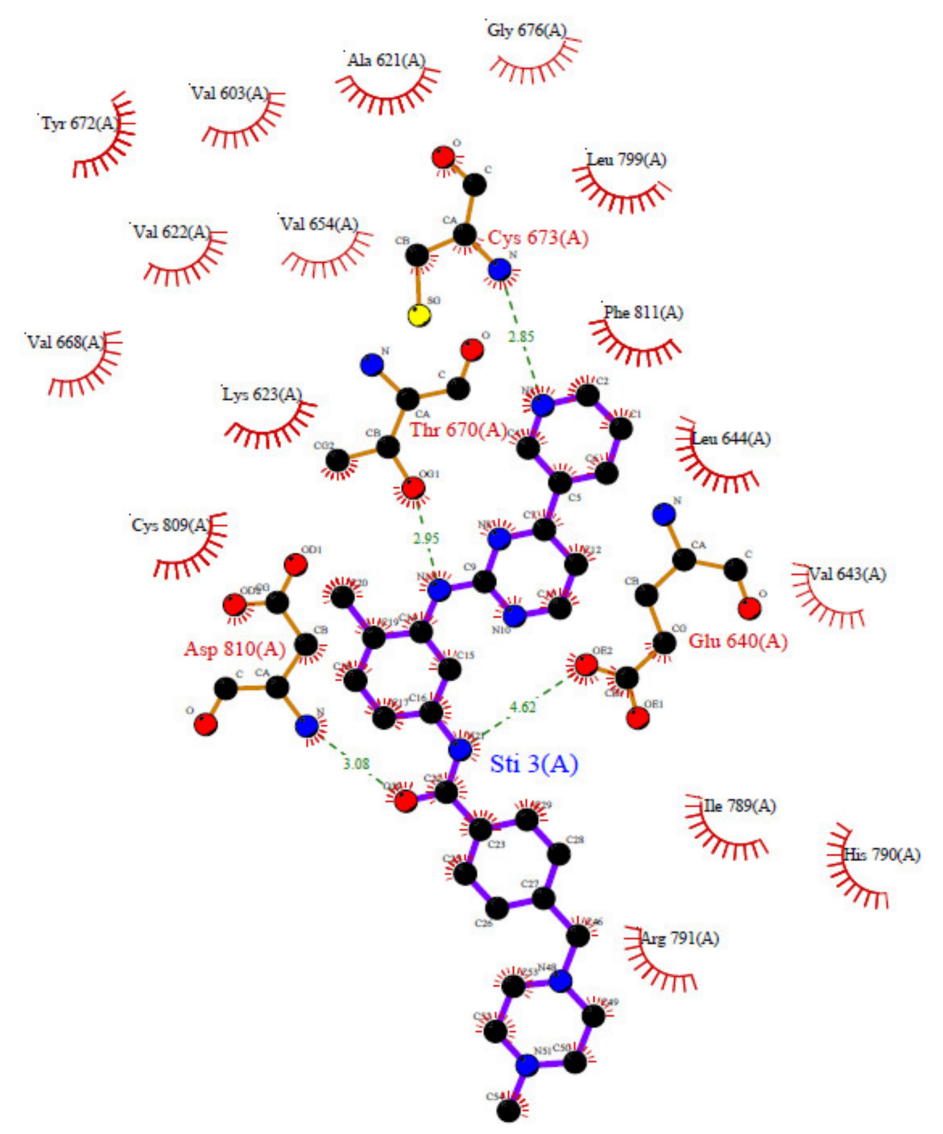

Figure 10. The LIGPLOT of interactions involving the co-crystallized ligand (Imatinib, Gleevec or STI) revealing the most relevant amino acids (E640, T670, C673 and D810) involved in the inhibitor binding into c-kit kinase (PDB: 1t46), through PDBsum database.

\subsubsection{AutoDock Binding Affinities of the Synthesized Compounds into C-Kit Tyrosine Kinase}

On applying the flexible docking of the 5-deazaalloxazine derivatives into the binding site of PTK (PDB: 1t46), the test compounds revealed reasonable binding free energy $\left(\Delta G_{\mathrm{b}}\right)$ compared to the natively bound STI-571 ligand (Table 3). The promising poses were exhibited by compounds $\mathbf{2} \mathbf{b}, \mathbf{2 e}, \mathbf{3} \mathbf{d}$, $3 \mathbf{e}, 3 \mathbf{i}, 3 \mathbf{m}$ and $4 \mathbf{a}-\mathbf{d}$, that showed binding free energies $\left(\Delta G_{\mathrm{b}}\right)$ in the range of -13.71 to $-12.33 \mathrm{kcal} / \mathrm{mol}$ within RMSD range of 1.31-7.88 $\AA$ and interacting by 1-3 hydrogen bonds. 
Table 3. The best compounds docked by flexible docking results (AutoDock 4.2$)$, considering the binding free energies $\left(\Delta G_{b}\right)$ and inhibition constants $\left(K_{\mathrm{i}}\right)$ of 5-deazalloxazine derivatives docked into c-kit PTK (1t46).

\begin{tabular}{|c|c|c|c|c|c|c|}
\hline \multirow{2}{*}{ Comp. } & \multirow{2}{*}{$\Delta G_{\mathrm{b}}{ }^{\mathrm{a}}(\mathrm{kcal} / \mathrm{mol})$} & \multirow{2}{*}{$K_{\mathrm{i}}^{\mathbf{b}}$} & \multicolumn{3}{|c|}{ Hydrogen Bonds } & \multirow{2}{*}{$\operatorname{RMSD}^{c}(\AA)$} \\
\hline & & & Atoms of Comp. & Amino Acids & The Most Relevant Amino Acids & \\
\hline $2 b$ & -13.04 & $274.65 \mathrm{pM}$ & $\mathrm{N}^{10}$ & $\mathrm{HN}$ of D810 & D810 & 1.31 \\
\hline $2 e$ & -12.60 & $577.10 \mathrm{pM}$ & $\begin{array}{c}3-\mathrm{NH} \\
4-\mathrm{C}=\mathrm{O}\end{array}$ & $\begin{array}{c}\mathrm{O}=\mathrm{C} \text { of I789 } \\
\mathrm{HS} \text { of } \mathrm{C} 788\end{array}$ & - & 7.28 \\
\hline $3 \mathbf{a}$ & -11.87 & $2.00 \mathrm{nM}$ & $\begin{array}{c}\mathrm{N}^{1} \\
2-\mathrm{NH} \\
\text { Terminal OH }\end{array}$ & $\begin{array}{l}\mathrm{HN} \text { of } \mathrm{D} 810 \\
\mathrm{O}=\mathrm{C} \text { of } \mathrm{E} 640 \\
\mathrm{O}=\mathrm{C} \text { of D810 }\end{array}$ & $\begin{array}{l}\mathrm{E} 640 \\
\mathrm{D} 810\end{array}$ & 0.86 \\
\hline $3 d$ & -13.07 & $261.56 \mathrm{pM}$ & $\begin{array}{c}2-\mathrm{NH} \\
3-\mathrm{NH} \\
4-\mathrm{C}=\mathrm{O}\end{array}$ & $\begin{array}{l}\mathrm{OH} \text { of } \mathrm{T} 670 \\
\mathrm{O}=\mathrm{C} \text { of } \mathrm{E} 671 \\
\mathrm{HN} \text { of } \mathrm{C} 673\end{array}$ & $\begin{array}{l}\text { T670 } \\
\text { E671 } \\
\text { C673 }\end{array}$ & 6.41 \\
\hline $3 e$ & -12.35 & $889.03 \mathrm{pM}$ & $\begin{array}{c}\text { 3-NH } \\
\text { Terminal OH }\end{array}$ & $\begin{array}{l}\mathrm{O}=\mathrm{C} \text { of } \mathrm{D} 810 \\
\mathrm{O}=\mathrm{C} \text { of } \mathrm{E} 640\end{array}$ & $\begin{array}{l}\text { E640 } \\
\text { D810 }\end{array}$ & 3.07 \\
\hline $3 \mathrm{~h}$ & -11.07 & $7.68 \mathrm{nM}$ & $\begin{array}{c}\text { 3-NH } \\
\text { Terminal OH } \\
\text { 3-NH }\end{array}$ & $\begin{array}{l}\mathrm{OH} \text { of } \mathrm{T} 670 \\
\mathrm{O}=\mathrm{C} \text { of } \mathrm{E} 640 \\
\mathrm{O}=\mathrm{C} \text { of } \mathrm{E} 671\end{array}$ & $\begin{array}{l}\text { E640 } \\
\text { T670 } \\
\text { T670 }\end{array}$ & 6.13 \\
\hline $3 \mathbf{i}$ & -13.71 & $88.93 \mathrm{pM}$ & $\begin{array}{l}4-\mathrm{C}=\mathrm{O} \\
2-\mathrm{NH}\end{array}$ & $\begin{array}{l}\mathrm{HN} \text { of } \mathrm{C} 673 \\
\mathrm{OH} \text { of } \mathrm{T} 670\end{array}$ & $\begin{array}{l}\text { C673 } \\
\text { E671 }\end{array}$ & 6.82 \\
\hline $3 \mathbf{j}$ & -11.96 & $1.72 \mathrm{nM}$ & $\begin{array}{c}2-\mathrm{NH} \\
\text { Terminal HO }\end{array}$ & $\begin{array}{l}\mathrm{O}=\mathrm{C} \text { of } \mathrm{D} 677 \\
\mathrm{HN} \text { of } \mathrm{N} 680\end{array}$ & - & 10.33 \\
\hline $3 \mathrm{k}$ & -11.64 & $2.92 \mathrm{nM}$ & $4-\mathrm{C}=\mathrm{O}$ & $\mathrm{HN}$ of $\mathrm{C} 673$ & C673 & 7.82 \\
\hline $3 m$ & $\begin{array}{l}-12.86 \\
-12.42\end{array}$ & $\begin{array}{l}373.23 \mathrm{pM} \\
782.55 \mathrm{pM}\end{array}$ & $\begin{array}{l}4-\mathrm{C}=\mathrm{O} \\
4-\mathrm{C}=\mathrm{O}\end{array}$ & $\mathrm{HN}$ of $\mathrm{C} 673$ & $\begin{array}{l}\text { C673 } \\
\text { C673 }\end{array}$ & $\begin{array}{l}7.71 \\
7.44\end{array}$ \\
\hline $4 b$ & -12.41 & $806.85 \mathrm{pM}$ & $\begin{array}{c}7-\mathrm{O} \\
4-\mathrm{C}=\mathrm{O}\end{array}$ & $\begin{array}{l}\mathrm{HO} \text { of T670 } \\
\text { HN of C673 }\end{array}$ & $\begin{array}{l}\text { T670 } \\
\text { C673 }\end{array}$ & 7.88 \\
\hline $\begin{array}{l}4 \mathrm{c} \\
4 \mathrm{~d}\end{array}$ & $\begin{array}{l}-12.56 \\
-12.33\end{array}$ & $\begin{array}{l}624.08 \mathrm{pM} \\
917.97 \mathrm{pM}\end{array}$ & $\begin{array}{l}4-\mathrm{C}=\mathrm{O} \\
4-\mathrm{C}=\mathrm{O}\end{array}$ & $\begin{array}{l}\mathrm{HN} \text { of C673 } \\
\mathrm{HN} \text { of } \mathrm{C} 673\end{array}$ & $\begin{array}{l}\text { C673 } \\
\text { C673 }\end{array}$ & $\begin{array}{l}7.56 \\
7.57\end{array}$ \\
\hline $4 e$ & -11.88 & $1.97 \mathrm{nM}$ & $\begin{array}{c}3-\mathrm{NH} \\
4-\mathrm{C}=\mathrm{O}\end{array}$ & $\begin{array}{c}\mathrm{O}=\mathrm{C} \text { of } \mathrm{I} 789 \\
\mathrm{HS} \text { of } \mathrm{C} 788\end{array}$ & - & 8.91 \\
\hline $4 \mathrm{~g}$ & -12.22 & $1.10 \mathrm{nM}$ & $\begin{array}{l}3-\mathrm{NH} \\
4-\mathrm{C}=\mathrm{O} \\
4-\mathrm{C}=\mathrm{O}\end{array}$ & $\begin{array}{c}\mathrm{O}=\mathrm{C} \text { of } \mathrm{I789} \\
\mathrm{HS} \text { of } \mathrm{C} 788 \\
\mathrm{HN} \text { of } \mathrm{K} 623\end{array}$ & - & 8.44 \\
\hline $5 a$ & -11.86 & $2.03 \mathrm{nM}$ & $\begin{array}{l}\text { 3-NH } \\
2-\mathrm{NH}^{1} \\
2-\mathrm{NH}^{1}\end{array}$ & $\begin{array}{l}\mathrm{O}=\mathrm{C} \text { of } \mathrm{D} 810 \\
\mathrm{O}=\mathrm{C} \text { of } \mathrm{D} 810 \\
\mathrm{O}=\mathrm{C} \text { of } \mathrm{E} 640\end{array}$ & $\begin{array}{l}\text { E640 } \\
\text { D810 }\end{array}$ & 2.46 \\
\hline $5 b$ & -10.45 & $21.92 \mathrm{nM}$ & $4-\mathrm{C}=\mathrm{O}$ & $\mathrm{HN}$ of C673 & C673 & 8.04 \\
\hline STI ${ }^{d}$ & -16.42 & $915.03 \mathrm{fM}$ & $\begin{array}{c}\mathrm{HNC}=\mathrm{O} \\
\mathrm{Ph}-\mathrm{NH}\end{array}$ & $\begin{array}{l}\mathrm{HN} \text { of D810 } \\
\mathrm{OH} \text { of T670 }\end{array}$ & $\begin{array}{l}\text { T670 } \\
\text { D810 }\end{array}$ & 0.17 \\
\hline
\end{tabular}

${ }^{\mathrm{a}}$ Binding free energy, ${ }^{\mathrm{b}}$ Inhibition constant, ${ }^{\mathrm{c}}$ Root mean square deviation, ${ }^{\mathrm{d}}$ Imatinib: the co-crystallized ligand. 
The significant PTK inhibition of compound $\mathbf{2 b}$ with $\mathrm{IC}_{50}$ against CCRF-HSB-2 and KB tumor cell lines of 23.66 and $26.73 \mu \mathrm{M}$, respectively and compound $3 \boldsymbol{h}$ with $\mathrm{IC}_{50} \%$ against MCF-7 and HeLa tumor cells of 0.17 and $2.0 \mu \mathrm{M}$, respectively were correlated with their binding affinities. Where they were docked into PTK (PDB: 1t46) as depicted in Figure 11 compared to the bound native ligand. Compound $\mathbf{2 b}$ revealed higher binding affinity with $\Delta G_{\mathrm{b}}:-13.04 \mathrm{kcal} / \mathrm{mol}$ and one hydrogen bond within RMSD of $1.31 \AA$. Whereas, compound $3 \mathrm{~h}$ exhibited less binding affinity into with $\Delta G_{\mathrm{b}}$ of $-11.07 \mathrm{kcal} / \mathrm{mol}$ within RMSD of $6.13 \AA$. 3h was bound through two hydrogen bonds. This results indicated that compound $\mathbf{2 b}$ is predicted to be a significant lead compound for PTK inhibition by its appropriate fitting into the binding site.

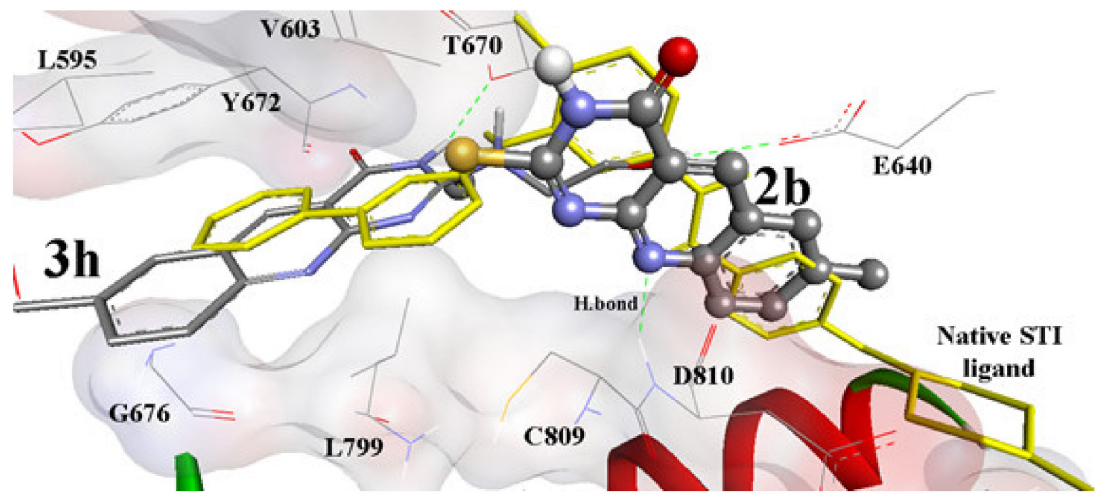

Figure 11. The comparative binding affinities of compound $\mathbf{2 b}$ (colored by element, ball and stick) and 3h (colored by element, sticks) into the binding site of protein Tyrosine kinase (PTK) (1t46). They showed one and two hydrogen bonds with D810, E640 and T670 amino acids, respectively. The STI ligand is shown as yellow sticks. The hydrogen bonds are drawn as green dashed lines.

On the other hand, the flexible docking of compounds $2 \boldsymbol{e}, \mathbf{5} \mathbf{a}$ and $\mathbf{5 b}$, exhibited comparable binding affinities with $\Delta G_{\mathrm{b}}$ in the range of -12.60 to $-10.45 \mathrm{kcal} / \mathrm{mol}$ and $1-4$ hydrogen bonds, within RMSD in the range of $2.46-8.04 \AA$, as shown in Figure 12.

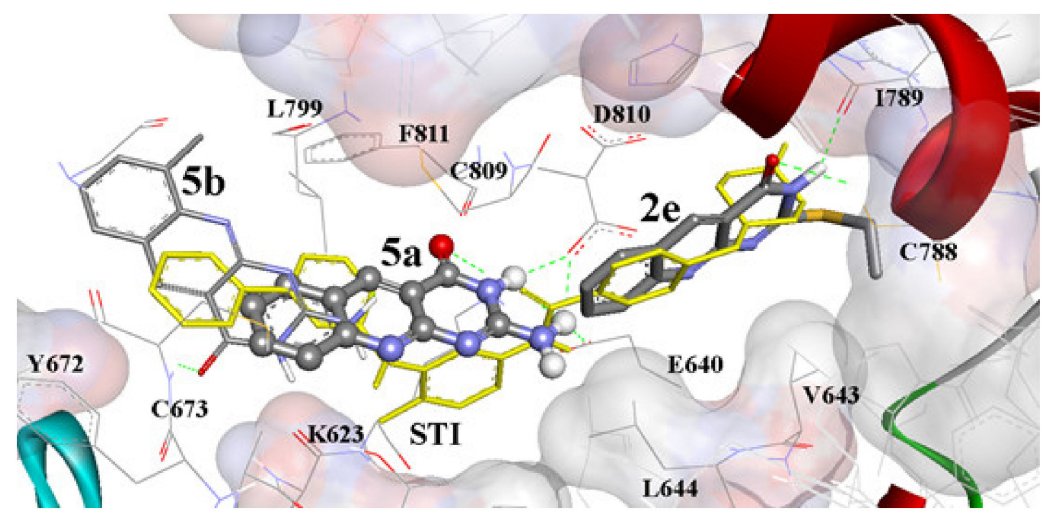

Figure 12. Differential docking affinities of compounds $2 \mathbf{e}$ (bold sticks), $5 a$ (ball and stick) and $5 \mathbf{b}$ (thin sticks) involving flexible docking into c-Kit PTK (1t46). Where compounds 2e and 5a seem docked exactly superimposed on the native STI ligand (yellow sticks) revealing two and four hydrogen bonds, whereas, $\mathbf{5 b}$ has deviated away with only one hydrogen bond. The c-Kit PTK is shown as a solid backbone ribbon and the hydrogen bonds as green dotted lines.

The correlation between the antiproliferative activities $\mathrm{IC}_{50}(\mu \mathrm{g} / \mathrm{mL})$ of compounds $(\mathbf{2} \mathbf{b}, \mathbf{3 d}, \mathbf{3 i}$, 3j, 3m, 3k, 4a, 4c, 4d, 4e and 5a) against human CCRF-HSB-2 cell line and the AutoDock inhibition constants $(\mathrm{Ki})$ was sensible with a correlation coefficient $\left(\mathrm{R}^{2}\right)$ of 0.867 as represented in Figure $13 \mathrm{~A}$. whereas, the correlation between $\mathrm{IC}_{50}(\mu \mathrm{g} / \mathrm{mL})$ of compounds $2 \mathbf{b}, \mathbf{3 a}, \mathbf{3 d}, \mathbf{3 i}, \mathbf{3} \mathbf{j}, \mathbf{3 m}, \mathbf{4 a}, \mathbf{4 c}, \mathbf{4 d}, \mathbf{4 e}, \mathbf{4 g}$ 
and $5 \mathrm{~b}$ against human $\mathrm{KB}$ cell line and AutoDock binding free energies $\left(\Delta G_{\mathrm{b}}\right)$ showed a reasonable correlation coefficient $\left(\mathrm{R}^{2}\right)$ of 0.834 as represented in Figure 13B.
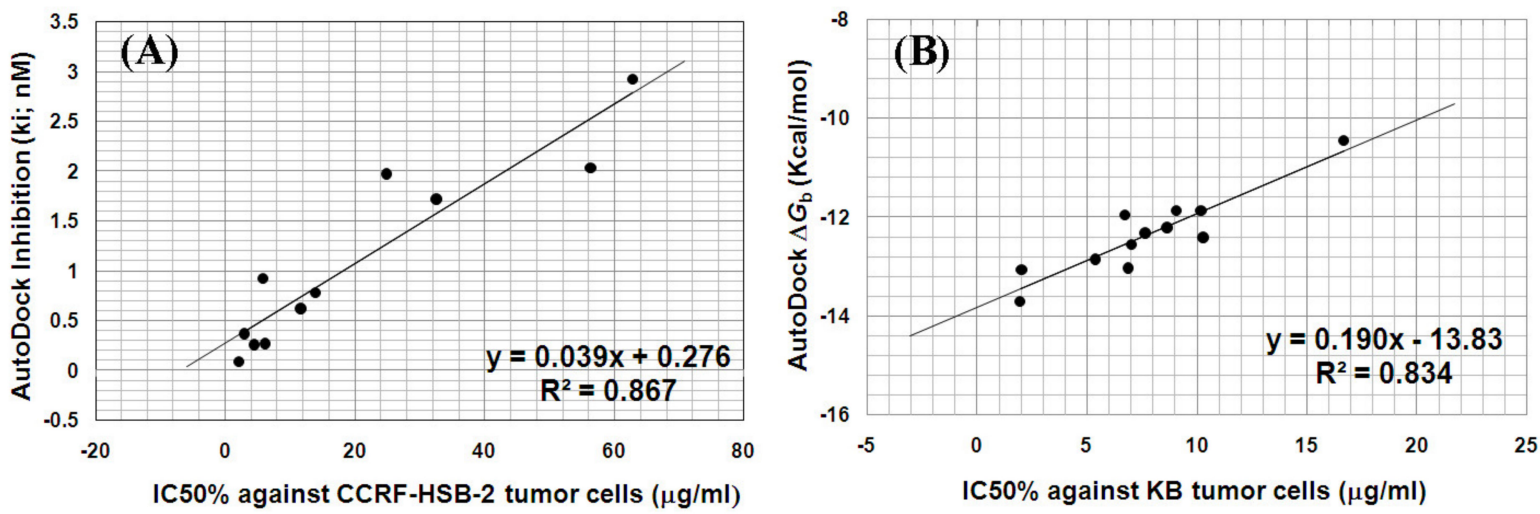

Figure 13. (A) Correlation between the $\mathrm{IC}_{50}(\mu \mathrm{g} / \mathrm{mL})$ against CCRF-HSB-2 tumor cell lines and AutoDock inhibition (Ki) for compounds $2 \mathbf{b}, 3 \mathbf{d}, \mathbf{3 i}, \mathbf{3 j}, \mathbf{3 m}, \mathbf{3 k}, \mathbf{4 a}, \mathbf{4 c}, \mathbf{4 d}, \mathbf{4 e}$ and $5 \mathbf{a}$. (B) Correlation between the $\mathrm{IC}_{50}(\mu \mathrm{g} / \mathrm{mL})$ against $\mathrm{KB}$ tumor cell lines and AutoDock binding free energy $\left(\Delta G_{\mathrm{b}}\right)$ for compounds $2 \mathrm{~b}, 3 \mathrm{a}, 3 \mathrm{~d}, 3 \mathrm{i}, 3 \mathrm{j}, 3 \mathrm{~m}, 4 \mathrm{a}, 4 \mathrm{c}, 4 \mathrm{~d}, 4 \mathrm{e}, 4 \mathrm{~g}$ and $5 \mathrm{~b}$.

To a lower extent, the correlation coefficient $\left(\mathrm{R}^{2}\right)$ between Autodock inhibition $(\mathrm{Ki})$ and $\mathrm{IC}_{50}(\mu \mathrm{M})$ against HeLa and MCF-7 tumor cell lines were 0.719 and 0.684 , respectively.

\section{Experimental}

\subsection{Synthesis and Structural Elucidation of 5-Deazaalloxazine Derivatives}

Using an electrothermal capillary melting point apparatus, MPs were measured as uncorrected. IR spectra were recorded using of infrared spectrophotometer of Perkin Elmer model $137 \mathrm{with} \mathrm{KBr}$ disk. A Varian Mercury VX-300 MHz spectrophotometer was used to analyze the ${ }^{1} \mathrm{H}-\mathrm{NMR}$ spectra and the chemical shift values were measured in in $\delta$ values (ppm). Tetramethylsilane (TMS) was used as an internal reference. The coupling constants are expressed in $\mathrm{Hz}$. Both protons of $\mathrm{NH}$ and $\mathrm{OH}$ protons were measured as exchangeable with $\mathrm{D}_{2} \mathrm{O}$. Gas chromatograph-mass spectrometer-single quadrupole (GCMC-QP)1000 EX SHIMADZU Gas Chromatography MS spectrometer was used to record the mass spectra. The elemental analyses were conducted by using an Automatic (Carbon; Hydroge; Nitrogen CHN) analyzer, Vario E1III, Elementary-Germany at the Microanalytical Center, Faculty of Science Cairo University, Egypt. All reagents in this study were used in a commercial quality and were not subjected for further purification. Drying of the organic solvents was performed by using suitable drying agents and stored over appropriate molecular sieves. Thin-layer chromatography (TLC) using pre-coated glass plates silica gel plates of 60F254-Merck was used for monitoring the progress of reactions and our fluorescent products were visualized by a UV lamp.

3.1.1. General Procedure for the Preparation of 2-Alkylthiopyrimido[4,5- $b$ ] Quinoline-4(3H)-Ones \{2-Deoxo-2-Alkylthio-5-Deazaalloxazines\} (2a-e)

A mixture of the appropriate 6-( $N$-arylamino)-2-alkylthiopyrimidin-4(3H)-one $(1,0.01 \mathrm{~mole})$ and $\mathrm{POCl}_{3}(7.7 \mathrm{~g}, 0.05$ mole $)$ in $(10 \mathrm{~mL})$ of anhydrous DMF was heated with stirring at $90{ }^{\circ} \mathrm{C}$ for $1-2 \mathrm{~h}$. Then, the reaction mixture was poured onto ice/water mixture and neutralized at $\mathrm{pH} 7$ by aqueous ammonia. The separated yellow crystals were filtered off, then washed with water, dried and recrystallized by using DMF-H2O to produce the products as pale-yellow needles in $72-86 \%$ yields.

2-(Methylthio)pyrimido[4,5-b]quinoline-4(3H)-one (2a): Yield (1.75 g, 72\%, DMF-H 2 O); m.p. $292-294{ }^{\circ} \mathrm{C}$, as reported [8]. 
7-Methyl-2-(methylthio)pyrimido[4,5-b]quinoline-4(3H)-one (2b): Yield (2.0 g, 78\%, DMF- $\left.\mathrm{H}_{2} \mathrm{O}\right)$; m.p. 244-246 ${ }^{\circ} \mathrm{C}$; UV (EtOH): $\lambda_{\max } \mathrm{nm}\left(\log \varepsilon / \mathrm{dm}^{3} \mathrm{~mol}^{-1} \mathrm{~cm}^{-1}\right): 254$ (4.03), 278sh (4.06), 285 (4.08), 366 (3.55); IR $\left(v_{\mathrm{cm}^{-1}}{ }^{-1}\right): 3421(\mathrm{NH}), 1672(\mathrm{C}=\mathrm{O}) ;{ }^{1} \mathrm{H}-\mathrm{NMR}$ [( $\left.\left(\mathrm{CD}_{3}\right)_{2} \mathrm{SO}-\mathrm{d}_{6}\right]: \delta 2.51(3 \mathrm{H}, \mathrm{s}, 7-\mathrm{Me}), 2.65(3 \mathrm{H}, \mathrm{s}, 2-\mathrm{SMe})$, $7.73\left(1 \mathrm{H}, \mathrm{d}, J_{8,9}=6.0 \mathrm{~Hz}, 9-\mathrm{H}\right), 7.90\left(1 \mathrm{H}, \mathrm{d}, J_{8,9}=6.0 \mathrm{~Hz}, 8-\mathrm{H}\right), 7.92(1 \mathrm{H}, \mathrm{s}, 6-\mathrm{H}), 9.07(1 \mathrm{H}, \mathrm{s}, 5-\mathrm{H}), 12.61$ $\left(1 \mathrm{H}\right.$, br s, $\mathrm{NH}, \mathrm{D}_{2} \mathrm{O}$ exchangeable); \% CHN analysis: Anal. Calcd for $\mathrm{C}_{13} \mathrm{H}_{11} \mathrm{~N}_{3} \mathrm{OS}: \mathrm{C}, 60.68 ; \mathrm{H}, 4.31 ; \mathrm{N}$, 16.33. Found: C, 60.49; H, 4.22; N, 16.69; MSEI, $m / z(\%): 257$ ( $\left.\mathrm{M}^{+}, 95 \%\right), 242$ (6\%), $226(100 \%), 155$ (82\%).

7-Methoxy-2-(methylthio)pyrimido[4,5-b]quinoline-4(3H)-one (2c): Yield (2.10 g, 77\%, DMF- $\left.\mathrm{H}_{2} \mathrm{O}\right)$; m.p. 222-224 ${ }^{\circ} \mathrm{C}$; UV (EtOH): $\lambda_{\max } \mathrm{nm}\left(\log \varepsilon / \mathrm{dm}^{3} \mathrm{~mol}^{-1} \mathrm{~cm}^{-1}\right): 230$ (4.36), 266sh (4.39), 285 (4.40), 401 (3.51); IR $\left(v_{\mathrm{cm}^{-1}}\right)^{-1} 3399(\mathrm{NH}), 1677(\mathrm{C}=\mathrm{O}) ;{ }^{1} \mathrm{H}-\mathrm{NMR}\left[\left(\mathrm{CD}_{3}\right)_{2} \mathrm{SO}-\mathrm{d}_{6}\right]: \delta 2.56(3 \mathrm{H}, \mathrm{s}, 2-\mathrm{SMe}), 3.91(3 \mathrm{H}, \mathrm{s}, 7-\mathrm{OMe})$, $7.57\left(1 \mathrm{H}, \mathrm{d}, J_{8,9}=9.0 \mathrm{~Hz}, 8-\mathrm{H}\right), 7.59(1 \mathrm{H}, \mathrm{s}, 6-\mathrm{H}), 7.93\left(1 \mathrm{H}, \mathrm{d}, J_{8,9}=9.0 \mathrm{~Hz}, 9-\mathrm{H}\right), 9.01(1 \mathrm{H}, \mathrm{s}, 5-\mathrm{H}), 12.68$ $\left(1 \mathrm{H}\right.$, br s, NH, $\mathrm{D}_{2} \mathrm{O}$ exchangeable); \% CHN analysis: Anal. Calcd for $\mathrm{C}_{13} \mathrm{H}_{11} \mathrm{~N}_{3} \mathrm{O}_{2} \mathrm{~S} .0 .5$ DMF: C, 56.20; $\mathrm{H}, 4.72 ; \mathrm{N}, 15.82$. Found: $\mathrm{C}, 55.98 ; \mathrm{H}, 4.52 ; \mathrm{N}, 15.55 ; \mathrm{MSEI}, \mathrm{m} / z(\%): 273\left(\mathrm{M}^{+}, 40 \%\right), 256(11 \%), 249(36 \%)$, $55(100 \%)$.

9-Methyl-2-(methylthio)pyrimido[4,5-b]quinoline-4(3H)-one (2d): Yield (2.20 g, 86\%, DMF- $\left.\mathrm{H}_{2} \mathrm{O}\right)$; m.p. 200-202 ${ }^{\circ} \mathrm{C}$; UV (EtOH): $\lambda_{\max } \mathrm{nm}\left(\log \varepsilon / \mathrm{dm}^{3} \mathrm{~mol}^{-1} \mathrm{~cm}^{-1}\right): 244$ (4.35), 279sh (4.49), 287 (4.55), 367 (3.81); IR $\left(v_{\mathrm{cm}^{-1}}\right): 3412(\mathrm{NH}), 1681(\mathrm{C}=\mathrm{O}) ;{ }^{1} \mathrm{H}-\mathrm{NMR}\left[\mathrm{CDCl}_{3}-\mathrm{d}_{6}\right]: \delta 2.54(3 \mathrm{H}, \mathrm{s}, 9-\mathrm{Me}), 2.85(3 \mathrm{H}, \mathrm{s}, 2-\mathrm{SMe})$, 7.46-7.48 (1H, m, 7-H), 7.71-7.73 (1H, m, 8-H), 7.83-7.85 (1H, m, 6-H), $9.14(1 \mathrm{H}, \mathrm{s}, 5-\mathrm{H}), 11.78(1 \mathrm{H}, \mathrm{br} \mathrm{s}$, $\mathrm{NH}, \mathrm{D}_{2} \mathrm{O}$ exchangeable); \% CHN analysis: Anal. Calcd for $\mathrm{C}_{13} \mathrm{H}_{11} \mathrm{~N}_{3} \mathrm{OS}: \mathrm{C}, 60.68 ; \mathrm{H}, 4.31 ; \mathrm{N}, 16.33$. Found: C, 60.35; H, 4.63; N, 16.01; MSEI, $m / z(\%): 257\left(\mathrm{M}^{+}, 65 \%\right), 208(100 \%), 154(81 \%)$.

2-(Ethylthio)pyrimido[4,5-b] quinoline-4(3H)-one (2e): Yield (1.90 g, 74\%, DMF- $\left.\mathrm{H}_{2} \mathrm{O}\right)$; m.p. $240-242{ }^{\circ} \mathrm{C}$; $\mathrm{UV}(\mathrm{EtOH}): \lambda_{\max } \mathrm{nm}\left(\log \varepsilon / \mathrm{dm}^{3} \mathrm{~mol}^{-1} \mathrm{~cm}^{-1}\right): 243$ (4.35), 269sh (4.40), 284 (4.53), 362 (3.79); IR $\left(v_{\mathrm{cm}^{-1}}\right)$ : $3416(\mathrm{NH}), 1680(\mathrm{C}=\mathrm{O}) ;{ }^{1} \mathrm{H}-\mathrm{NMR}\left[\mathrm{CDCl}_{3}-\mathrm{d}_{6}\right]: \delta 1.52\left(3 \mathrm{H}, \mathrm{t}, J=6.0 \mathrm{~Hz}, 2-\mathrm{SCH}_{2} \mathrm{CH}_{3}\right), 3.50(2 \mathrm{H}, \mathrm{q}$, $\left.J=6.0 \mathrm{~Hz}, 2-\mathrm{SCH}_{2} \mathrm{CH}_{3}\right), 7.60\left(1 \mathrm{H}, \mathrm{t}, J_{6,7}=J_{7,8}=7.2 \mathrm{~Hz}, 7-\mathrm{H}\right), 7.91\left(1 \mathrm{H}, \mathrm{t}, J_{7,8}=J_{8,9}=7.2 \mathrm{~Hz}, 8-\mathrm{H}\right), 8.02$ $\left(1 \mathrm{H}, \mathrm{d}, J_{8,9}=7.2 \mathrm{~Hz}, 9-\mathrm{H}\right), 8.26\left(1 \mathrm{H}, \mathrm{d}, J_{6,7}=7.2 \mathrm{~Hz}, 6-\mathrm{H}\right), 9.18(1 \mathrm{H}, \mathrm{s}, 5-\mathrm{H}), 9.43\left(1 \mathrm{H}, \mathrm{br} \mathrm{s}, \mathrm{NH}, \mathrm{D}_{2} \mathrm{O}\right.$ exchangeable); \% CHN analysis: Anal. Calcd for $\mathrm{C}_{13} \mathrm{H}_{11} \mathrm{~N}_{3} \mathrm{OS}: \mathrm{C}, 60.68 ; \mathrm{H}, 4.31 ; \mathrm{N}, 16.33$. Found: $\mathrm{C}$, 61.02; H, 4.56; N, 16.61; MSEI, $m / z(\%): 257\left(\mathrm{M}^{+}, 34 \%\right), 229$ (34\%), $170(32 \%), 141(94 \%)$ and $114(100 \%)$.

3.1.2. General Procedure for the Preparation of 2-(Substituted alkyl amino)-pyrimido[4,5- $b$ ] quinoline-4(3H)-ones \{2-(substituted alkyl amino)-2-deoxo-5-deazaalloxazines\} (3a-m)

A 0.01 mole of 2-(methylthio)pyrimido[4,5- $b$ ]quinolin-4(3H)-one derivatives (2) was mixed and refluxed with stirring with 0.1 moles of the appropriate amine for 7-9 $\mathrm{h}$. The clear solution of the yellow product was kept overnight in the refrigerator to allow precipitation of yellow crystals which were collected by filtration to get the first crop. The excess amine was removed from the filtrate by concentrating in vacuo, then the residue was treated with ether then water to get the second crop free from amine. The collected solids were dried and recrystallized from $\mathrm{DMF} / \mathrm{H}_{2} \mathrm{O}$ mixture to afford pure products with $60-88 \%$ as yellow needles.

2-(2-Hydroxyethylamino)pyrimido[4,5-b]quinoline-4(3H)-one (3a): Yield (2.1 g, 82\%, DMF- $\left.\mathrm{H}_{2} \mathrm{O}\right)$; m.p. 273-275 ${ }^{\circ} \mathrm{C}$; UV (EtOH): $\lambda_{\max } \mathrm{nm}\left(\log \varepsilon / \mathrm{dm}^{3} \mathrm{~mol}^{-1} \mathrm{~cm}^{-1}\right): 226$ (4.31), 261sh (4.25), 277 (4.34), 372 (3.49); IR $\left(v_{\mathrm{cm}^{-1}}\right)^{-1}: 3389(\mathrm{OH}), 3247(\mathrm{NH}), 1694(\mathrm{C}=\mathrm{O}) ;{ }^{1} \mathrm{H}-\mathrm{NMR}\left[\left(\mathrm{CD}_{3}\right)_{2} \mathrm{SO}-\mathrm{d}_{6}\right]: \delta 3.58-3.60\left(2 \mathrm{H}, \mathrm{m}, \mathrm{NCH}_{2}\right)$, 3.67-3.69 $\left(2 \mathrm{H}, \mathrm{m}, \mathrm{OCH}_{2}\right), 5.01\left(1 \mathrm{H}, \mathrm{br} \mathrm{s}, \mathrm{OH}, \mathrm{D}_{2} \mathrm{O}\right.$ exchangeable), $6.88\left(1 \mathrm{H}, \mathrm{br} \mathrm{s}, \mathrm{NH}, \mathrm{D}_{2} \mathrm{O}\right.$ exchangeable), $7.43\left(1 \mathrm{H}, \mathrm{t}, J_{6,7}=J_{7,8}=9.0 \mathrm{~Hz}, 7-\mathrm{H}\right), 7.78\left(1 \mathrm{H}, \mathrm{t}, J_{7,8}=J_{8,9}=9.0 \mathrm{~Hz}, 8-\mathrm{H}\right), 7.82\left(1 \mathrm{H}, \mathrm{d}, J_{8,9}=9.0 \mathrm{~Hz}, 9-\mathrm{H}\right)$, $8.06\left(1 \mathrm{H}, \mathrm{d}, J_{6,7}=9.0 \mathrm{~Hz}, 6-\mathrm{H}\right), 8.92(1 \mathrm{H}, \mathrm{s}, 5-\mathrm{H}), 11.10\left(1 \mathrm{H}, \mathrm{br} \mathrm{s}, \mathrm{NH}, \mathrm{D}_{2} \mathrm{O}\right.$ exchangeable); \% CHN analysis: Anal. Calcd for $\mathrm{C}_{13} \mathrm{H}_{12} \mathrm{~N}_{4} \mathrm{O}_{2}$ : C, 60.93; H, 4.72; N, 21.86. Found: $\mathrm{C}, 61.23 ; \mathrm{H}, 5.01 ; \mathrm{N}, 21.54$.

2-(Butylamino)pyrimido[4,5-b]quinoline-4(3H)-one (3b): Yield (1.60 g, 60\%, DMF- $\left.\mathrm{H}_{2} \mathrm{O}\right)$; m.p. $153-155^{\circ} \mathrm{C}$; UV (EtOH): $\lambda_{\max } \mathrm{nm}\left(\log \varepsilon / \mathrm{dm}^{3} \mathrm{~mol}^{-1} \mathrm{~cm}^{-1}\right): 243$ (4.36), 263 (4.42), 278sh (4.40), 370 (3.71); IR $\left(v_{\mathrm{cm}^{-1}}\right)$ : 3431, $3256(\mathrm{NH}), 1691(\mathrm{C}=\mathrm{O}) ;{ }^{1} \mathrm{H}-\mathrm{NMR}$ [ $\left(\mathrm{CD}_{3}\right)_{2} \mathrm{SO}-\mathrm{d}_{6}$ ]: $\delta 0.91\left(3 \mathrm{H}, \mathrm{br}\right.$ s, $\left.2-\mathrm{NH}\left(\mathrm{CH}_{2}\right)_{3} \mathrm{CH}_{3}\right), 1.36-1.38$ $\left(2 \mathrm{H}, \mathrm{m}, 2-\mathrm{NH}\left(\mathrm{CH}_{2}\right)_{2} \mathrm{CH}_{2}-\right), 1.52-1.54\left(2 \mathrm{H}, \mathrm{m}, 2-\mathrm{NH}-\mathrm{CH}_{2} \mathrm{CH}_{2}-\right), 3.16-3.18\left(2 \mathrm{H}, \mathrm{m}, 2-\mathrm{NHCH}_{2}-\right), 6.90(1 \mathrm{H}$, 
br s, $\mathrm{NH}, \mathrm{D}_{2} \mathrm{O}$ exchangeable), 7.44-7.46 $(1 \mathrm{H}, \mathrm{m}, 7-\mathrm{H}), 7.59-7.61(1 \mathrm{H}, \mathrm{m}, 8-\mathrm{H}), 7.78-7.80(1 \mathrm{H}, \mathrm{m}, 9-\mathrm{H})$, 8.04-8.06 (1H, m, 6-H), $8.90(1 \mathrm{H}, \mathrm{s}, 5-\mathrm{H}), 10.65\left(1 \mathrm{H}, \mathrm{br} \mathrm{s}, \mathrm{NH}, \mathrm{D}_{2} \mathrm{O}\right.$ exchangeable); \% CHN analysis: Anal. Calcd for $\mathrm{C}_{15} \mathrm{H}_{16} \mathrm{~N}_{4} \mathrm{O} .0 .3 \mathrm{H}_{2} \mathrm{O}: \mathrm{C}, 65.82 ; \mathrm{H}, 6.11 ; \mathrm{N}, 20.47$. Found: $\mathrm{C}, 65.98 ; \mathrm{H}, 5.97 ; \mathrm{N}, 20.26$.

2-(Propylamino)pyrimido[4,5-b]quinoline-4(3H)-one (3c): Yield (1.90 g, 75\%, DMF- $\left.\mathrm{H}_{2} \mathrm{O}\right) ;$ m.p. $254-256{ }^{\circ} \mathrm{C}$; UV (EtOH): $\lambda_{\max } \mathrm{nm}\left(\log \varepsilon / \mathrm{dm}^{3} \mathrm{~mol}^{-1} \mathrm{~cm}^{-1}\right): 243$ (4.0), 261sh (4.12), 278 (4.26), 372 (3.41); IR $\left(v_{\mathrm{cm}^{-1}}\right)$ : $3448,3232(\mathrm{NH}), 1634(\mathrm{C}=\mathrm{O}) ;{ }^{1} \mathrm{H}-\mathrm{NMR}\left[\left(\mathrm{CD}_{3}\right)_{2} \mathrm{SO}-\mathrm{d}_{6}\right]: \delta 0.90-0.95\left(3 \mathrm{H}, \mathrm{m}, 2-\mathrm{NH}\left(\mathrm{CH}_{2}\right)_{2} \mathrm{CH}_{3}\right), 1.52-1.60$ $\left(2 \mathrm{H}, \mathrm{m}, 2-\mathrm{NHCH}_{2} \mathrm{CH}_{2}-\right), 3.35-3.37\left(2 \mathrm{H}, \mathrm{m}, 2-\mathrm{NHCH}_{2-}\right), 6.68\left(1 \mathrm{H}, \mathrm{br} \mathrm{s}, \mathrm{NH}, \mathrm{D}_{2} \mathrm{O}\right.$ exchangeable), 7.43 $\left(1 \mathrm{H}, \mathrm{t}, J_{6,7}=J_{7,8}=8.4 \mathrm{~Hz}, 7-\mathrm{H}\right), 7.76\left(1 \mathrm{H}, \mathrm{t}, J_{7,8}=J_{8,9}=8.4 \mathrm{~Hz}, 8-\mathrm{H}\right), 7.82\left(1 \mathrm{H}, \mathrm{d}, J_{8,9}=8.4 \mathrm{~Hz}, 9-\mathrm{H}\right), 8.04$ $\left(1 \mathrm{H}, \mathrm{d}, J_{6,7}=8.4 \mathrm{~Hz}, 6-\mathrm{H}\right), 8.91(1 \mathrm{H}, \mathrm{s}, 5-\mathrm{H}), 11.02\left(1 \mathrm{H}, \mathrm{br} \mathrm{s}, \mathrm{NH}, \mathrm{D}_{2} \mathrm{O}\right.$ exchangeable); \% CHN analysis: Anal. Calcd for $\mathrm{C}_{14} \mathrm{H}_{14} \mathrm{~N}_{4} \mathrm{O}$ : C, 66.13; H, 5.55; N, 22.03. Found: $\mathrm{C}, 65.98 ; \mathrm{H}, 5.34 ; \mathrm{N}, 22.35 ; \mathrm{MSEI}, \mathrm{m} / \mathrm{z}$ (\%): $254\left(\mathrm{M}^{+}, 25 \%\right), 225(76 \%), 212(100 \%)$.

2-(Cyclohexylamino)pyrimido[4,5-b]quinoline-4(3H)-one (3d): Yield (2 g, 68\%, DMF- $\left.\mathrm{H}_{2} \mathrm{O}\right)$; m.p. $229-231^{\circ} \mathrm{C}$; UV (EtOH): $\lambda_{\max } \mathrm{nm}\left(\log \varepsilon / \mathrm{dm}^{3} \mathrm{~mol}^{-1} \mathrm{~cm}^{-1}\right): 242$ (4.26), 262sh (4.37), 279 (4.49), $370(3.71) ; \mathrm{IR}\left(v_{\mathrm{cm}^{-1}}\right)$ : $3425,3250(\mathrm{NH}), 1688(\mathrm{C}=\mathrm{O}){ }^{1} \mathrm{H}-\mathrm{NMR}\left[\left(\mathrm{CD}_{3}\right)_{2} \mathrm{SO}-\mathrm{d}_{6}\right]: \delta 1.29-1.35\left(2 \mathrm{H}, \mathrm{m}, 4^{\prime}-\mathrm{CH}_{2}\right), 1.52-1.71(4 \mathrm{H}, \mathrm{m}$, $3^{\prime}$ and $\left.5^{\prime}-\mathrm{CH}_{2}\right), 1.95-2.20\left(4 \mathrm{H}, \mathrm{m}, 2^{\prime}-\mathrm{CH}_{2}\right.$ and $\left.6^{\prime}-\mathrm{CH}_{2}\right), 2.97-2.99\left(1 \mathrm{H}, \mathrm{m}, 1^{\prime}-\mathrm{CH}-\right), 3.93(1 \mathrm{H}, \mathrm{br} \mathrm{s}, \mathrm{NH}$, $\mathrm{D}_{2} \mathrm{O}$ exchangeable), 7.40-7.42 (1H, m, 7-H), 7.80-7.82 (2H, m, 8 and 9-H), 8.04-8.06 (1H, m, 6-H), 8.91 $(1 \mathrm{H}, \mathrm{s}, 5-\mathrm{H}), 10.67\left(1 \mathrm{H}, \mathrm{br} \mathrm{s}, \mathrm{NH}, \mathrm{D}_{2} \mathrm{O}\right.$ exchangeable); \% CHN analysis: Anal. Calcd for $\mathrm{C}_{17} \mathrm{H}_{18} \mathrm{~N}_{4} \mathrm{O}: \mathrm{C}$, 69.37; H, 6.16; N, 19.03. Found: C, 68.01; H, 5.89; N, 18.85; MSEI, $\mathrm{m} / z(\%): 294\left(\mathrm{M}^{+}, 12 \%\right), 212(89 \%), 57$ $(100 \%)$.

2-(2-Hydroxyethylamino)-7-(methoxy)pyrimido[4,5-b]quinoline-4(3H)-one (3e): Yield (2.4 g, 84\%, DMF- $\mathrm{H}_{2} \mathrm{O}$ ); m.p. 190-192 ${ }^{\circ} \mathrm{C}$; UV (EtOH): $\lambda_{\max } \mathrm{nm}\left(\log \varepsilon / \mathrm{dm}^{3} \mathrm{~mol}^{-1} \mathrm{~cm}^{-1}\right): 224$ (4.08), 277 (4.16), 327 (3.69), 401 (3.23); IR $\left(v_{\mathrm{cm}^{-1}}{ }^{-1}\right): 3301(\mathrm{OH}), 3218(\mathrm{NH}), 1693(\mathrm{C}=\mathrm{O}) ;{ }^{1} \mathrm{H}-\mathrm{NMR}\left[\left(\mathrm{CD}_{3}\right)_{2} \mathrm{SO}-\mathrm{d}_{6}\right]: \delta 3.68-3.70(2 \mathrm{H}, \mathrm{m}$, $\left.\mathrm{NCH}_{2}\right), 3.72(3 \mathrm{H}, \mathrm{s}, 7-\mathrm{OMe}), 3.85-3.87\left(2 \mathrm{H}, \mathrm{m}, \mathrm{OCH}_{2}\right), 4.72\left(1 \mathrm{H}, \mathrm{br} \mathrm{s}, \mathrm{OH}, \mathrm{D}_{2} \mathrm{O}\right.$ exchangeable $), 6.52(1 \mathrm{H}, \mathrm{br}$ s, $\mathrm{NH}, \mathrm{D}_{2} \mathrm{O}$ exchangeable), 7.05-7.07 $(1 \mathrm{H}, \mathrm{m}, 9-\mathrm{H}), 7.63(1 \mathrm{H}, \mathrm{s}, 6-\mathrm{H}), 7.80-7.82(1 \mathrm{H}, \mathrm{m}, 8-\mathrm{H}), 8.79(1 \mathrm{H}, \mathrm{s}$, 5-H), $9.43\left(1 \mathrm{H}\right.$, br s, $\mathrm{NH}, \mathrm{D}_{2} \mathrm{O}$ exchangeable); \% CHN analysis: Anal. Calcd for $\mathrm{C}_{14} \mathrm{H}_{14} \mathrm{~N}_{4} \mathrm{O}_{3}$ : C, 58.73; H, 4.93; N, 19.57. Found: C, 58.21; H, 5.29; N, 19.25; MSEI, $m / z(\%): 287\left(\mathrm{M}^{+}+1,17 \%\right), 270(42 \%), 255$ $(17 \%), 108(100 \%)$.

2-Butylamino-7-(methoxy)pyrimido[4,5-b]quinoline-4(3H)-one (3f): Yield (2.2 g, 74\%, DMF- $\left.\mathrm{H}_{2} \mathrm{O}\right)$; m.p. 242-243 ${ }^{\circ} \mathrm{C}$; UV (EtOH): $\lambda_{\max } \mathrm{nm}\left(\log \varepsilon / \mathrm{dm}^{3} \mathrm{~mol}^{-1} \mathrm{~cm}^{-1}\right): 230$ (4.37), 269 (4.41), 370 (3.67), 394 (3.66); IR $\left(v_{\mathrm{cm}^{-1}}{ }^{-1}\right): 3398,3269(\mathrm{NH}), 1694(\mathrm{C}=\mathrm{O}) ;{ }^{1} \mathrm{H}-\mathrm{NMR}\left[\left(\mathrm{CD}_{3}\right)_{2} \mathrm{SO}-\mathrm{d}_{6}\right]: \delta 0.91(3 \mathrm{H}, \mathrm{t}, J=7.2 \mathrm{~Hz}$, 2-NH( $\left.\left(\mathrm{CH}_{2}\right)_{3} \mathrm{CH}_{3}\right), 1.37-1.39\left(2 \mathrm{H}, \mathrm{m}, 2-\mathrm{NH}\left(\mathrm{CH}_{2}\right)_{2} \mathrm{CH}_{2}-\right)$, 1.53-1.55 (2H, m, 2-NH- $\left.\mathrm{CH}_{2} \mathrm{CH}_{2}-\right)$, 3.75-3.77 $\left(2 \mathrm{H}, \mathrm{m}, 2-\mathrm{NHCH}_{2}-\right), 3.87(3 \mathrm{H}, \mathrm{s}, 7-\mathrm{OMe}), 6.89\left(1 \mathrm{H}, \mathrm{br} \mathrm{s}, \mathrm{NH}, \mathrm{D}_{2} \mathrm{O}\right.$ exchangeable), 7.46-7.49 $(2 \mathrm{H}, \mathrm{m}, 6$ and 9-H), 7.73-7.75 (1H, m, 8-H), $8.83(1 \mathrm{H}, \mathrm{s}, 5-\mathrm{H}), 10.98\left(1 \mathrm{H}, \mathrm{br} \mathrm{s}, \mathrm{NH}, \mathrm{D}_{2} \mathrm{O}\right.$ exchangeable); \% $\mathrm{CHN}$ analysis: Anal. Calcd for $\mathrm{C}_{16} \mathrm{H}_{18} \mathrm{~N}_{4} \mathrm{O}_{2}$ : $\mathrm{C}, 64.41 ; \mathrm{H}, 6.08 ; \mathrm{N}, 18.78$. Found: $\mathrm{C}, 64.13 ; \mathrm{H}, 5.82 ; \mathrm{N}, 19.04$; MSEI, $m / z$ (\%): 298 (M+ $\left.\mathrm{M}^{+}, 55 \%\right), 282(8 \%), 270(26 \%), 255$ (100\%), 242 (94\%), $227(59 \%)$.

7-Methoxy-2-(propylamino)pyrimido[4,5-b]quinoline-4(3H)-one (3g): Yield (2.5 g, 88\%, DMF- $\left.\mathrm{H}_{2} \mathrm{O}\right)$; m.p. 268-270 ${ }^{\circ} \mathrm{C}$; UV (EtOH): $\lambda_{\max } \mathrm{nm}\left(\log \varepsilon / \mathrm{dm}^{3} \mathrm{~mol}^{-1} \mathrm{~cm}^{-1}\right)$ : 229 (4.36), 267 (4.45), 370 (3.60), 396 (3.69); IR $\left(v_{\mathrm{cm}}{ }^{-1}\right): 3391,3241(\mathrm{NH}), 1694(\mathrm{C}=\mathrm{O}) ;{ }^{1} \mathrm{H}-\mathrm{NMR}\left[\left(\mathrm{CD}_{3}\right)_{2} \mathrm{SO}-\mathrm{d}_{6}\right]: 0.91\left(3 \mathrm{H}, \mathrm{t}, J=6.3 \mathrm{~Hz}, 2-\mathrm{NH}\left(\mathrm{CH}_{2}\right)_{2} \mathrm{CH}_{3}\right)$, $1.58\left(2 \mathrm{H}\right.$, hexet, $\left.J=6.3 \mathrm{~Hz}, 2-\mathrm{NHCH}_{2} \mathrm{CH}_{2}-\right), 3.73-3.76\left(2 \mathrm{H}, \mathrm{m}, 2-\mathrm{NHCH}_{2}-\right), 3.86(3 \mathrm{H}, \mathrm{s}, 7-\mathrm{OMe}), 6.52(1 \mathrm{H}$, br s, NH, $\mathrm{D}_{2} \mathrm{O}$ exchangeable), $7.43\left(1 \mathrm{H}, \mathrm{d}, J_{8,9}=9 \mathrm{~Hz}, 9-\mathrm{H}\right), 7.52(1 \mathrm{H}, \mathrm{s}, 6-\mathrm{H}), 7.74\left(1 \mathrm{H}, \mathrm{d}, J_{8,9}=9 \mathrm{~Hz}\right.$, 8-H), $8.81(1 \mathrm{H}, \mathrm{s}, 5-\mathrm{H}), 10.93\left(1 \mathrm{H}, \mathrm{br} \mathrm{s}, \mathrm{NH}, \mathrm{D}_{2} \mathrm{O}\right.$ exchangeable); \% $\mathrm{CHN}$ analysis: Anal. Calcd for $\mathrm{C}_{15} \mathrm{H}_{16} \mathrm{~N}_{4} \mathrm{O}_{2}: \mathrm{C}, 63.37 ; \mathrm{H}, 5.67 ; \mathrm{N}, 19.71$. Found: $\mathrm{C}, 63.14 ; \mathrm{H}, 5.35 ; \mathrm{N}, 19.94 ; \mathrm{MSEI}, m / z(\%): 284\left(\mathrm{M}^{+}\right.$, $53 \%), 269(14 \%), 255(83 \%), 242(100 \%), 227(48 \%)$.

2-(2-Hydroxyethylamino)-7-(methyl)pyrimido[4,5-b]quinoline-4(3H)-one (3h): Yield (2.1 g, 78\%, DMF- $\left.\mathrm{H}_{2} \mathrm{O}\right)$; m.p. 200-210 ${ }^{\circ} \mathrm{C}$; UV (EtOH): $\lambda_{\max } \mathrm{nm}\left(\log \varepsilon / \mathrm{dm}^{3} \mathrm{~mol}^{-1} \mathrm{~cm}^{-1}\right): 228$ (4.32), 265 (4.44), 281sh (4.35), 360 (3.65); IR $\left(v_{\mathrm{cm}}{ }^{-1}\right): 3385(\mathrm{OH}), 3243(\mathrm{NH}), 1696(\mathrm{C}=\mathrm{O}) ;{ }^{1} \mathrm{H}-\mathrm{NMR}\left[\left(\mathrm{CD}_{3}\right)_{2} \mathrm{SO}-\mathrm{d}_{6}\right]: \delta 2.65(3 \mathrm{H}, \mathrm{s}, 7-\mathrm{Me})$, 3.49-3.51 (2H, m, NCH $)$, 3.58-3.60 (2H, m, OCH $)_{2}, 4.95\left(1 \mathrm{H}, \mathrm{br} \mathrm{s}, \mathrm{OH}, \mathrm{D}_{2} \mathrm{O}\right.$ exchangeable), $6.75(1 \mathrm{H}, \mathrm{br}$ s, NH, $\mathrm{D}_{2} \mathrm{O}$ exchangeable), 7.32-7.34 $(1 \mathrm{H}, \mathrm{m}, 9-\mathrm{H}), 7.62(1 \mathrm{H}, \mathrm{s}, 6-\mathrm{H}), 7.89-7.81(1 \mathrm{H}, \mathrm{m}, 8-\mathrm{H}), 8.89(1 \mathrm{H}, \mathrm{s}$, 
5-H), $11.12\left(1 \mathrm{H}\right.$, br s, $\mathrm{NH}, \mathrm{D}_{2} \mathrm{O}$ exchangeable); \% CHN analysis: Anal. Calcd for $\mathrm{C}_{14} \mathrm{H}_{14} \mathrm{~N}_{4} \mathrm{O}_{2}$ : C, 62.21; H, 5.22; N, 20.73. Found: C, 62.53; H, 5.54; N, 20.52.

2-Cyclohexylamino-7-(methyl)pyrimido[4,5-b]quinoline-4(3H)-one (3i): Yield (2.0 g, 65\%, DMF- $\left.\mathrm{H}_{2} \mathrm{O}\right)$; m.p. 220-225 ${ }^{\circ} \mathrm{C}$; UV (EtOH): $\lambda_{\max } \mathrm{nm}\left(\log \varepsilon / \mathrm{dm}^{3} \mathrm{~mol}^{-1} \mathrm{~cm}^{-1}\right): 244$ (4.39), 265 (4.45), 281sh (4.37), 401 (3.73); IR $\left(v_{\mathrm{cm}}{ }^{-1}\right): 3414,3245(\mathrm{NH}), 1687(\mathrm{C}=\mathrm{O}) ;{ }^{1} \mathrm{H}-\mathrm{NMR}\left[\left(\mathrm{CD}_{3}\right)_{2} \mathrm{SO}-\mathrm{d}_{6}\right]: \delta 1.26-1.33\left(2 \mathrm{H}, \mathrm{m}, 4^{\prime}-\mathrm{CH}_{2}\right), 1.83-1.90$ $\left(4 \mathrm{H}, \mathrm{m}, 3^{\prime}\right.$ and $\left.5^{\prime}-\mathrm{CH}_{2}\right), 2.14-2.29\left(4 \mathrm{H}, \mathrm{m}, 2^{\prime}-\mathrm{CH}_{2}\right.$ and $\left.6^{\prime}-\mathrm{CH}_{2}\right), 2.63(3 \mathrm{H}, \mathrm{s}, 7-\mathrm{Me}), 3.04\left(1 \mathrm{H}, \mathrm{m}, 1^{\prime}-\mathrm{CH}_{2}\right)$, $3.95\left(1 \mathrm{H}\right.$, br s, NH, $\mathrm{D}_{2} \mathrm{O}$ exchangeable), $7.31\left(1 \mathrm{H}, \mathrm{d}, J_{8,9}=8.1 \mathrm{~Hz}, 9-\mathrm{H}\right), 7.60(1 \mathrm{H}, \mathrm{s}, 6-\mathrm{H}), 7.87(1 \mathrm{H}, \mathrm{d}$, $\left.J_{8,9}=8.1 \mathrm{~Hz}, 8-\mathrm{H}\right), 8.84(1 \mathrm{H}, \mathrm{s}, 5-\mathrm{H}), 10.20\left(1 \mathrm{H}, \mathrm{br} \mathrm{s}, \mathrm{NH}, \mathrm{D}_{2} \mathrm{O}\right.$ exchangeable); \% $\mathrm{CHN}$ analysis: Anal. Calcd for $\mathrm{C}_{18} \mathrm{H}_{20} \mathrm{~N}_{4} \mathrm{O}: \mathrm{C}, 70.11 ; \mathrm{H}, 6.54 ; \mathrm{N}, 18.17$. Found: C, 69.81; H, 6.78; N, 17.97; MSEI, $m / z$ (\%): 308 $\left(\mathrm{M}^{+}, 16 \%\right), 226(100 \%)$.

2-(2-Hydroxyethylamino)-9-(methyl)pyrimido[4,5-b]quinoline-4(3H)-one (3j): Yield (1.8 g, 67\%, DMF- $\left.\mathrm{H}_{2} \mathrm{O}\right)$; m.p. $200-210^{\circ} \mathrm{C}$; UV (EtOH): $\lambda_{\max } \mathrm{nm}\left(\log \varepsilon / \mathrm{dm}^{3} \mathrm{~mol}^{-1} \mathrm{~cm}^{-1}\right): 224$ (4.27), 265 (4.40), 281sh (4.31), 370 (3.72); IR $\left(v_{\mathrm{cm}^{-1}}\right)$ : $3394(\mathrm{OH}), 3235(\mathrm{NH}), 1695(\mathrm{C}=\mathrm{O}) ;{ }^{1} \mathrm{H}-\mathrm{NMR}$ [( $\left.\left(\mathrm{CD}_{3}\right)_{2} \mathrm{SO}-\mathrm{d}_{6}\right]: \delta 2.65(3 \mathrm{H}, \mathrm{s}, 9-\mathrm{Me})$, 3.51-3.53 $\left(2 \mathrm{H}, \mathrm{m}, \mathrm{NCH}_{2}\right), 3.60-3.61\left(2 \mathrm{H}, \mathrm{m}, \mathrm{OCH}_{2}\right), 4.94\left(1 \mathrm{H}, \mathrm{br} \mathrm{s}, \mathrm{OH}, \mathrm{D}_{2} \mathrm{O}\right.$ exchangeable $), 6.72(1 \mathrm{H}, \mathrm{br}$ $\mathrm{s}, \mathrm{NH}, \mathrm{D}_{2} \mathrm{O}$ exchangeable), $7.33\left(1 \mathrm{H}, \mathrm{t}, J_{6,7}=J_{7,8}=7.5 \mathrm{~Hz}, 7-\mathrm{H}\right), 7.63\left(1 \mathrm{H}, \mathrm{d}, J_{7,8}=7.5 \mathrm{~Hz}, 8-\mathrm{H}\right), 7.89(1 \mathrm{H}$, $\left.\mathrm{d}, J_{6,7}=7.5 \mathrm{~Hz}, 6-\mathrm{H}\right), 8.84(1 \mathrm{H}, \mathrm{s}, 5-\mathrm{H}), 11.03\left(1 \mathrm{H}, \mathrm{br} \mathrm{s}, \mathrm{NH}, \mathrm{D}_{2} \mathrm{O}\right.$ exchangeable); \% CHN analysis: Anal. Calcd for $\mathrm{C}_{14} \mathrm{H}_{14} \mathrm{~N}_{4} \mathrm{O}_{2}$ : C, 62.21; H, 5.22; N, 20.73. Found: C, 62.49; H, 5.01; N, 20.13; MSEI, $m / z(\%)$ : $270\left(\mathrm{M}^{+}, 32 \%\right), 252(31 \%), 239(95 \%), 226(100 \%)$.

2-Butylamino-9-(methyl)pyrimido[4,5-b]quinoline-4(3H)-one (3k): Yield (2.3 g, 82\%, DMF- $\left.\mathrm{H}_{2} \mathrm{O}\right)$; m.p. 214-216 ${ }^{\circ} \mathrm{C}$ UV (EtOH): $\lambda_{\max } \mathrm{nm}\left(\log \varepsilon / \mathrm{dm}^{3} \mathrm{~mol}^{-1} \mathrm{~cm}^{-1}\right): 245$ (4.54), 264 (4.70), 281sh (4.54), 360 (3.92); IR $\left(v_{\mathrm{cm}}{ }^{-1}\right)$ : 3412, $3237(\mathrm{NH}), 1698(\mathrm{C}=\mathrm{O}) ;{ }^{1} \mathrm{H}-\mathrm{NMR}\left[\left(\mathrm{CD}_{3}\right)_{2} \mathrm{SO}_{-} \mathrm{d}_{6}\right]: \delta 0.93(3 \mathrm{H}, \mathrm{t}, J=6.9 \mathrm{~Hz}$, 2-NH $\left.\left(\mathrm{CH}_{2}\right)_{3} \mathrm{CH}_{3}\right), 1.36-1.38\left(2 \mathrm{H}, \mathrm{m}, 2-\mathrm{NH}\left(\mathrm{CH}_{2}\right)_{2} \mathrm{CH}_{2}-\right), 1.52-1.56\left(2 \mathrm{H}, \mathrm{m}, 2-\mathrm{NHCH}_{2} \mathrm{CH}_{2}-\right), 2.64(3 \mathrm{H}, \mathrm{s}$, 9-Me), 3.18-3.20 (2H, m, 2-NHCH $\left.2_{2}^{-}\right), 6.65\left(1 \mathrm{H}, \mathrm{br} \mathrm{s}, \mathrm{NH}, \mathrm{D}_{2} \mathrm{O}\right.$ exchangeable), 7.31-7.33 (1H, m, 7-H), 7.60-7.62 (1H, m, 8-H), 7.87-7.89 (1H, m, 6-H), $8.86(1 \mathrm{H}, \mathrm{s}, 5-\mathrm{H}), 11.25\left(1 \mathrm{H}, \mathrm{br} \mathrm{s}, \mathrm{NH}, \mathrm{D}_{2} \mathrm{O}\right.$ exchangeable); \% CHN analysis: Anal. Calcd for $\mathrm{C}_{16} \mathrm{H}_{18} \mathrm{~N}_{4} \mathrm{O}$ : C, 68.06; H, 6.43; N, 19.84. Found: C, 67.83; H, 6.58; N, 20.19; MSEI, $m / z(\%): 282\left(\mathrm{M}^{+}, 43 \%\right), 266(4 \%), 253(19 \%), 239$ (73\%), $226(100 \%)$.

9-Methyl-2-(propylamino)pyrimido[4,5-b]quinoline-4(3H)-one (31): Yield (2.1 g, 78\%, DMF- $\left.\mathrm{H}_{2} \mathrm{O}\right)$; m.p. 270-272 ${ }^{\circ} \mathrm{C} ; \mathrm{UV}(\mathrm{EtOH}): \lambda_{\max } \mathrm{nm}\left(\log \varepsilon / \mathrm{dm}^{3} \mathrm{~mol}^{-1} \mathrm{~cm}^{-1}\right): 244$ (4.29), 265 (4.48), 281sh (4.36), 373 (3.56); IR $\left(v_{\mathrm{cm}}{ }^{-1}\right): 3369,3233(\mathrm{NH}), 1695(\mathrm{C}=\mathrm{O}) ;{ }^{1} \mathrm{H}-\mathrm{NMR}\left[\left(\mathrm{CD}_{3}\right)_{2} \mathrm{SO}-\mathrm{d}_{6}\right]: \delta 0.94-0.95\left(3 \mathrm{H}, \mathrm{m}, 2-\mathrm{NH}\left(\mathrm{CH}_{2}\right)_{2} \mathrm{CH}_{3}\right)$, 1.58-1.60 (2H, m, 2- $\left.\mathrm{NHCH}_{2} \mathrm{CH}_{2}-\right), 2.65(3 \mathrm{H}, \mathrm{s}, 9-\mathrm{Me}), 3.37-3.39\left(2 \mathrm{H}, \mathrm{m}, 2-\mathrm{NHCH}_{2}-\right), 6.63(1 \mathrm{H}, \mathrm{br} \mathrm{s}, \mathrm{NH}$, $\mathrm{D}_{2} \mathrm{O}$ exchangeable), $7.32\left(1 \mathrm{H}, \mathrm{t}, J_{6,7}=J_{7,8}=7.6 \mathrm{~Hz}, 7-\mathrm{H}\right), 7.61\left(1 \mathrm{H}, \mathrm{d}, J_{7,8}=7.6 \mathrm{~Hz}, 8-\mathrm{H}\right), 7.88(1 \mathrm{H}, \mathrm{d}$, $\left.J_{6,7}=7.6 \mathrm{~Hz}, 6-\mathrm{H}\right), 8.88(1 \mathrm{H}, \mathrm{s}, 5-\mathrm{H}), 10.99\left(1 \mathrm{H}, \mathrm{br} \mathrm{s}, \mathrm{NH}, \mathrm{D}_{2} \mathrm{O}\right.$ exchangeable); \% CHN analysis: Anal. Calcd for $\mathrm{C}_{15} \mathrm{H}_{16} \mathrm{~N}_{4} \mathrm{O}: \mathrm{C}, 67.15 ; \mathrm{H}, 6.01 ; \mathrm{N}, 20.88$. Found: C, 67.41; H, 6.37; N, 20.69; MSEI, $m / z$ (\%): 268 $\left(\mathrm{M}^{+}, 44 \%\right), 254(16 \%), 240(79 \%), 226(100 \%)$.

2-Cyclohexylamino-9-(methyl)pyrimido[4,5-b]quinoline-4(3H)-one (3m): Yield (2.60 g, 84\%, DMF- $\left.\mathrm{H}_{2} \mathrm{O}\right)$; m.p. $178-180^{\circ} \mathrm{C}$; UV (EtOH): $\lambda_{\max } \mathrm{nm}\left(\log \varepsilon / \mathrm{dm}^{3} \mathrm{~mol}^{-1} \mathrm{~cm}^{-1}\right): 243$ (4.12), 264 (4.27), 281sh (4.10), 378 (3.68); IR $\left(v_{\mathrm{cm}}{ }^{-1}\right): 3410,3220(\mathrm{NH}), 1688(\mathrm{C}=\mathrm{O}) ;{ }^{1} \mathrm{H}-\mathrm{NMR}\left[\left(\mathrm{CD}_{3}\right)_{2} \mathrm{SO}-\mathrm{d}_{6}\right]: \delta 1.26-1.40\left(2 \mathrm{H}, \mathrm{m}, 4^{\prime}-\mathrm{CH}_{2}\right)$, 1.44-1.72 $\left(4 \mathrm{H}, \mathrm{m}, 3^{\prime}\right.$ and $\left.5^{\prime}-\mathrm{CH}_{2}\right), 1.74-1.96\left(4 \mathrm{H}, \mathrm{m}, 2^{\prime}-\mathrm{CH}_{2}\right.$ and $\left.6^{\prime}-\mathrm{CH}_{2}\right), 2.65(3 \mathrm{H}, \mathrm{s}, 9-\mathrm{Me}), 2.89(1 \mathrm{H}, \mathrm{m}$, $\left.1^{\prime}-\mathrm{CH}\right), 3.93\left(1 \mathrm{H}, \mathrm{br} \mathrm{s}, \mathrm{NH}, \mathrm{D}_{2} \mathrm{O}\right.$ exchangeable), $7.32\left(1 \mathrm{H}, \mathrm{t}, J_{6,7}=J_{7,8}=6 \mathrm{~Hz}, 7-\mathrm{H}\right), 7.63\left(1 \mathrm{H}, \mathrm{d}, J_{7,8}=6 \mathrm{~Hz}\right.$, 8-H), $7.89\left(1 \mathrm{H}, \mathrm{d}, J_{6,7}=6 \mathrm{~Hz}, 6-\mathrm{H}\right), 8.87(1 \mathrm{H}, \mathrm{s}, 5-\mathrm{H}), 10.23\left(1 \mathrm{H}, \mathrm{br} \mathrm{s}, \mathrm{NH}, \mathrm{D}_{2} \mathrm{O}\right.$ exchangeable); \% CHN analysis: Anal. Calcd for $\mathrm{C}_{18} \mathrm{H}_{20} \mathrm{~N}_{4}$ O.0.4DMF: C, 68.30; H, 6.81; N, 18.25. Found: $\mathrm{C}, 68.59 ; \mathrm{H}, 6.64 ; \mathrm{N}$, 18.05 .

3.1.3. General Procedure for the Preparation of 2-(heterocyclic substituted)pyrimido [4,5-b] quinoline-4(3H)-ones \{2-(heterocyclic substituted)-2-deoxo-5-deazaalloxazines\} (4a-g)

A mixture of 2-(methyl)thiopyrimido[4,5-b]quinolin-4(3H)-one derivatives $(2,0.01$ mole) and the appropriate amine $(0.2-0.3$ mole) in DMF $(30 \mathrm{~mL})$ was refluxed $24-30 \mathrm{~h}$ with stirring. The generated clear yellow solution was kept overnight in the refrigerator so that yellow crystals could be collected 
through filtration to get the first crop. Excessive amine was removed from the filtrate by evaporation under vacuo and the residue was treated with ether then water to get the second crop free from amine. The collected solids were dried and recrystallized by a DMF- $\mathrm{H}_{2} \mathrm{O}$ mixture to afford pure products as yellow needles in $64-75 \%$ yields.

2-(Piperidin-1-yl)pyrimido[4,5-b]quinoline-4(3H)-one (4a): Yield (1.80 g, 64\%, DMF- $\left.\mathrm{H}_{2} \mathrm{O}\right)$; m.p. $228-230{ }^{\circ} \mathrm{C}$; $\mathrm{UV}(\mathrm{EtOH}): \lambda_{\max } \mathrm{nm}\left(\log \varepsilon / \mathrm{dm}^{3} \mathrm{~mol}^{-1} \mathrm{~cm}^{-1}\right)$ : 263sh (4.41), 283 (4.51), 370 (3.83), $412(3.86) ; \mathrm{IR}\left(v_{\mathrm{cm}}{ }^{-1}\right)$ : $3420(\mathrm{NH}), 1660(\mathrm{C}=\mathrm{O}) ;{ }^{1} \mathrm{H}-\mathrm{NMR}\left[\left(\mathrm{CD}_{3}\right)_{2} \mathrm{SO}-\mathrm{d}_{6}\right]: \delta 1.63-1.66\left(6 \mathrm{H}, \mathrm{m}, 3^{\prime}, 4^{\prime}\right.$ and $\left.5^{\prime}-\mathrm{CH}_{2}\right), 3.80-3.82(4 \mathrm{H}$, $\mathrm{m}, 2^{\prime}$ and $\left.6^{\prime}-\mathrm{N}-\mathrm{CH}_{2}\right), 7.48-7.50(1 \mathrm{H}, \mathrm{m}, 7-\mathrm{H}), 7.82-7.85(2 \mathrm{H}, \mathrm{m}, 8$ and 9-H), 8.07-8.09 $(1 \mathrm{H}, \mathrm{m}, 6-\mathrm{H}), 8.96$ $(1 \mathrm{H}, \mathrm{s}, 5-\mathrm{H}), 11.53\left(1 \mathrm{H}\right.$, br s, $\mathrm{NH}, \mathrm{D}_{2} \mathrm{O}$ exchangeable); \% $\mathrm{CHN}$ analysis: Anal. Calcd for $\mathrm{C}_{16} \mathrm{H}_{16} \mathrm{~N}_{4} \mathrm{O}: \mathrm{C}_{\text {, }}$ 68.55; H, 5.75; N, 19.99. Found: C, 68.39; H, 5.91; N, 19.76; MS, m/z (\%): $280\left(\mathrm{M}^{+}, 57 \%\right), 251$ (66\%), 225 $(39 \%), 55(100 \%)$.

7-Methoxy-2-(morpholin-4-yl)pyrimido[4,5-b]quinoline-4(3H)-one (4b): Yield (2.0 g, 64\%, DMF- $\left.{ }_{2} \mathrm{O}\right)$; m.p. 208-210 ${ }^{\circ} \mathrm{C}$; UV (EtOH): $\lambda_{\max } \mathrm{nm}\left(\log \varepsilon / \mathrm{dm}^{3} \mathrm{~mol}^{-1} \mathrm{~cm}^{-1}\right): 227$ (4.24), 269 (4.43), 276sh (4.41), 401 (3.66); IR $\left(v_{\mathrm{cm}}{ }^{-1}\right): 3418(\mathrm{NH}), 1612(\mathrm{C}=\mathrm{O}) ;{ }^{1} \mathrm{H}-\mathrm{NMR}\left[\left(\mathrm{CD}_{3}\right)_{2} \mathrm{SO}-\mathrm{d}_{6}\right]: \delta 3.22-3.27\left(4 \mathrm{H}, \mathrm{m}, 3^{\prime}\right.$ and $\left.5^{\prime}-\mathrm{NCH}_{2}\right)$, $3.76(3 \mathrm{H}, \mathrm{s}, 7-\mathrm{OMe}), 3.84-3.86\left(4 \mathrm{H}, \mathrm{m}, 2^{\prime}\right.$ and $\left.6^{\prime}-\mathrm{OCH}_{2}\right), 7.44-7.47(2 \mathrm{H}, \mathrm{m}, 6$ and 8-H), 7.71-7.73 $(1 \mathrm{H}$, m, 9-H), $8.80(1 \mathrm{H}, \mathrm{s}, 5-\mathrm{H}), 11.40\left(1 \mathrm{H}\right.$, br s, NH, $\mathrm{D}_{2} \mathrm{O}$ exchangeable); \% CHN analysis: Anal. Calcd for $\mathrm{C}_{16} \mathrm{H}_{16} \mathrm{~N}_{4} \mathrm{O}_{3}$. 0.2 $\mathrm{H}_{2} \mathrm{O}: \mathrm{C}, 60.83 ; \mathrm{H}, 5.23 ; \mathrm{N}, 17.73$. Found: $\mathrm{C}, 61.03 ; \mathrm{H}, 4.98 ; \mathrm{N}, 17.87 ; \mathrm{MSEI}, \mathrm{m} / \mathrm{z}(\%): 312$ $\left(\mathrm{M}^{+}, 71 \%\right), 255(100 \%), 226(28 \%)$.

9-Methyl-2-(morpholin-4-yl)pyrimido[4,5-b]quinoline-4(3H)-one (4c): Yield (2.1 g, 71\%, DMF- $\left.\mathrm{H}_{2} \mathrm{O}\right) ; \mathrm{m} . \mathrm{p}$. 248-250 ${ }^{\circ} \mathrm{C}$; UV (EtOH): $\lambda_{\max } \mathrm{nm}\left(\log \varepsilon / \mathrm{dm}^{3} \mathrm{~mol}^{-1} \mathrm{~cm}^{-1}\right): 244$ (4.33), 265 (4.39), 285sh (4.29), 400 (3.65); IR $\left(v_{\mathrm{cm}}{ }^{-1}\right): 3419(\mathrm{NH}), 1621(\mathrm{C}=\mathrm{O}) ;{ }^{1} \mathrm{H}-\mathrm{NMR}\left[\left(\mathrm{CD}_{3}\right)_{2} \mathrm{SO}-\mathrm{d}_{6}\right]: \delta 2.66(3 \mathrm{H}, \mathrm{s}, 9-\mathrm{Me}), 3.25-3.29(4 \mathrm{H}, \mathrm{m}$, $3^{\prime}$ and $\left.5^{\prime}-\mathrm{NCH}_{2}\right), 3.70-3.82\left(4 \mathrm{H}, \mathrm{m}, 2^{\prime}\right.$ and $\left.6^{\prime}-\mathrm{OCH}_{2}\right), 7.34-7.36(1 \mathrm{H}, \mathrm{m}, 7-\mathrm{H}), 7.55-7.57(1 \mathrm{H}, \mathrm{m}, 8-\mathrm{H})$, 7.96-7.98 (1H, m, 6-H), $8.80(1 \mathrm{H}, \mathrm{s}, 5-\mathrm{H}), 10.40\left(1 \mathrm{H}, \mathrm{br} \mathrm{s}, \mathrm{NH}, \mathrm{D}_{2} \mathrm{O}\right.$ exchangeable); \% CHN analysis: Anal. Calcd for $\mathrm{C}_{16} \mathrm{H}_{16} \mathrm{~N}_{4} \mathrm{O}_{2}$ : C, 64.85; H, 5.44; N, 18.91. Found: C, 65.12; H, 5.24; N, 19.22 .

9-Methyl-2-(piperidin-1-yl)pyrimido[4,5-b]quinoline-4(3H)-one (4d): Yield (1.90 g, 65\%, DMF- $\left.\mathrm{H}_{2} \mathrm{O}\right) ; \mathrm{m} . \mathrm{p}$. 220-222 ${ }^{\circ} \mathrm{C}$; UV (EtOH): $\lambda_{\max } \mathrm{nm}\left(\log \varepsilon / \mathrm{dm}^{3} \mathrm{~mol}^{-1} \mathrm{~cm}^{-1}\right): 246$ (4.40), 266 (4.47), 288sh (4.34), 401 (3.62); IR $\left(v_{\mathrm{cm}}{ }^{-1}\right): 3422(\mathrm{NH}), 1678(\mathrm{C}=\mathrm{O}){ }^{1}{ }^{1} \mathrm{H}-\mathrm{NMR}\left[\left(\mathrm{CD}_{3}\right)_{2} \mathrm{SO}-\mathrm{d}_{6}\right]: \delta 1.50-1.54\left(6 \mathrm{H}, \mathrm{m}, 3^{\prime}, 4^{\prime}\right.$ and $\left.5^{\prime}-\mathrm{CH}_{2}\right)$, $2.76(3 \mathrm{H}, \mathrm{s}, 9-\mathrm{Me}), 3.73-3.75\left(4 \mathrm{H}, \mathrm{m}, 2^{\prime}\right.$ and $\left.6^{\prime}-\mathrm{NCH}_{2}\right), 7.31-7.33(1 \mathrm{H}, \mathrm{m}, 7-\mathrm{H}), 7.62-7.64(1 \mathrm{H}, \mathrm{m}, 8-\mathrm{H})$, 7.88-7.90 (1H, m, 6-H), $8.88(1 \mathrm{H}, \mathrm{s}, 5-\mathrm{H}), 11.53\left(1 \mathrm{H}, \mathrm{br} \mathrm{s}, \mathrm{NH}, \mathrm{D}_{2} \mathrm{O}\right.$ exchangeable); \% CHN analysis: Anal. Calcd for $\mathrm{C}_{17} \mathrm{H}_{18} \mathrm{~N}_{4} \mathrm{O}$ : C, 69.37; H, 6.16; N, 19.03. Found: C, 69.09; H, 6.35; N, 19.31; MSEI, $m / z$ (\%): $294\left(\mathrm{M}^{+}, 16 \%\right), 266(8 \%), 253(23 \%), 239(25 \%), 225(100 \%)$.

2-(4-Phenylpiperazin-1-yl)pyrimido[4,5-b]quinoline-4-ol (4e): Yield (2.40 g, 67\%, DMF- $\left.{ }_{2} \mathrm{O}\right) ; \mathrm{m} . \mathrm{p}$. 172-174 ${ }^{\circ} \mathrm{C}$; UV (EtOH): $\lambda_{\max } \mathrm{nm}\left(\log \varepsilon / \mathrm{dm}^{3} \mathrm{~mol}^{-1} \mathrm{~cm}^{-1}\right): 261 \mathrm{sh}(4.62), 281$ (4.68), 370 (3.71), 410 (3.99); IR $\left(v_{\mathrm{cm}}{ }^{-1}\right)$ : 3421 (OH tautomer of $\left.\mathrm{C}=\mathrm{O}\right) ;{ }^{1} \mathrm{H}-\mathrm{NMR}\left[\left(\mathrm{CD}_{3}\right)_{2} \mathrm{SO}-\mathrm{d}_{6}\right]: \delta 3.03-3.04\left(4 \mathrm{H}, \mathrm{m}, 2^{\prime}\right.$ and 6'- $\left.\mathrm{NCH}_{2}\right), 3.49$ (1H, br s, OH, $\mathrm{D}_{2} \mathrm{O}$ exchangeable), 3.95-3.99 (4H, m, 3' and 5' $\left.-\mathrm{NCH}_{2}\right), 6.79(1 \mathrm{H}, \mathrm{dt}$, $\left.J_{3^{\prime \prime}, 4^{\prime \prime}}=J_{4^{\prime \prime}}, 5^{\prime \prime}=7.2 \mathrm{~Hz}, J_{2^{\prime \prime}, 4^{\prime \prime}}=J_{4^{\prime \prime}, 6^{\prime \prime}}=2.1 \mathrm{~Hz}, \mathrm{Ph}-\mathrm{pH}\right), 6.94\left(2 \mathrm{H}, \mathrm{dd}, J_{2^{\prime \prime}, 3^{\prime \prime}}=J_{5^{\prime \prime}, 6^{\prime \prime}}=7.2 \mathrm{~Hz}, J_{2^{\prime \prime}, 4^{\prime \prime}}=\right.$ $\left.J_{4^{\prime \prime}, 6^{\prime \prime}}=2.1 \mathrm{~Hz}, \mathrm{Ph}-\mathrm{oH}\right), 7.16-7.23(2 \mathrm{H}, \mathrm{m}, \mathrm{Ph}-\mathrm{mH}), 7.45\left(1 \mathrm{H}, \mathrm{t}, J_{6,7}=J_{7,8}=7.8 \mathrm{~Hz}, 7-\mathrm{H}\right), 7.76(1 \mathrm{H}, \mathrm{t}$, $\left.J_{7,8}=J_{8,9}=7.8 \mathrm{~Hz}, 8-\mathrm{H}\right), 7.82\left(1 \mathrm{H}, \mathrm{d}, J_{6,7}=7.8 \mathrm{~Hz}, 6-\mathrm{H}\right), 8.07\left(1 \mathrm{H}, \mathrm{d}, J_{8,9}=7.8 \mathrm{~Hz} 9-\mathrm{H}\right), 8.92(1 \mathrm{H}, \mathrm{s}, 5-\mathrm{H})$; \% CHN analysis: Anal. Calcd for $\mathrm{C}_{21} \mathrm{H}_{19} \mathrm{~N}_{5} \mathrm{O}: \mathrm{C}, 70.57 ; \mathrm{H}, 5.36 ; \mathrm{N}, 19.59$. Found: C, 70.23; $\mathrm{H}, 5.72 ; \mathrm{N}$, 19.32; MSEI, $m / z(\%): 357\left(\mathrm{M}^{+}, 4 \%\right)$ and $132(100 \%)$.

7-Methyl-2-(4-phenylpiperazin-1-yl)pyrimido[4,5-b]quinoline-4-ol (4f): Yield (2.70 g, 73\%, DMF- $\left.{ }_{2} \mathrm{O}\right) ; \mathrm{m} . \mathrm{p}$. 279-281 ${ }^{\circ} \mathrm{C}$; UV (EtOH): $\lambda_{\max } \mathrm{nm}\left(\log \varepsilon / \mathrm{dm}^{3} \mathrm{~mol}^{-1} \mathrm{~cm}^{-1}\right): 249$ (4.46), 286sh (4.15), 356 (3.50), 373 (3.48); IR $\left(v_{\mathrm{cm}}{ }^{-1}\right): 3431(\mathrm{OH}$ tautomer of $\mathrm{C}=\mathrm{O}) ;{ }^{1} \mathrm{H}-\mathrm{NMR}\left[\left(\mathrm{CD}_{3}\right)_{2} \mathrm{SO}-\mathrm{d}_{6}\right]: \delta 2.68(3 \mathrm{H}, \mathrm{s}, 7-\mathrm{Me}), 3.27-3.34(4 \mathrm{H}$, m, 2' and 6' $\left.-\mathrm{NCH}_{2}\right), 3.48\left(1 \mathrm{H}\right.$, br s, OH, $\mathrm{D}_{2} \mathrm{O}$ exchangeable), 3.93-3.96 (4H, m, 3' and 5'- $\left.\mathrm{NCH}_{2}\right), 6.85$ $\left(1 \mathrm{H}, \mathrm{t}, J_{3^{\prime \prime}, 4^{\prime \prime}}=J_{4^{\prime \prime}, 5^{\prime \prime}}=7.5 \mathrm{~Hz}, \mathrm{Ph}-\mathrm{pH}\right), 6.97\left(2 \mathrm{H}, \mathrm{d}, J_{2^{\prime \prime}}, 3^{\prime \prime}=J_{5^{\prime \prime}}, 6^{\prime \prime}=7.5 \mathrm{~Hz}, \mathrm{Ph}-\mathrm{oH}\right), 7.22-7.27(2 \mathrm{H}, \mathrm{m}$, $\mathrm{Ph}-\mathrm{mH}), 7.65\left(1 \mathrm{H}, \mathrm{d}, J_{8,9}=8.6 \mathrm{~Hz}, 9-\mathrm{H}\right), 7.92\left(1 \mathrm{H}, \mathrm{d}, J_{8,9}=8.6 \mathrm{~Hz}, 8-\mathrm{H}\right), 8.16(1 \mathrm{H}, \mathrm{s}, 6-\mathrm{H}), 8.93(1 \mathrm{H}, \mathrm{s}$, 5-H); \% CHN analysis: Anal. Calcd for $\mathrm{C}_{22} \mathrm{H}_{21} \mathrm{~N}_{5} \mathrm{O}: \mathrm{C}, 71.14 ; \mathrm{H}, 5.70 ; \mathrm{N}, 18.85$. Found: $\mathrm{C}, 71.35 ; \mathrm{H}$, 5.42; N, 18.47; MSEI, $m / z$ (\%): 371( $\mathrm{M}^{+}, 0.03 \%$, metastable ion), $162(95 \%), 121$ (100\%). 
9-Methyl-2-(4-phenylpiperazin-1-yl)pyrimido[4,5-b]quinoline-4-ol (4g): Yield (2.80 g, 75\%, DMF- $\left.\mathrm{H}_{2} \mathrm{O}\right)$; m.p. 281-283 ${ }^{\circ} \mathrm{C}$; UV (EtOH): $\lambda_{\max } \mathrm{nm}\left(\log \varepsilon / \mathrm{dm}^{3} \mathrm{~mol}^{-1} \mathrm{~cm}^{-1}\right): 266$ (4.52), 287sh (4.36), 359 (3.67), 370 (3.66); IR $\left(v_{\mathrm{cm}^{-1}}\right)^{-1}: 3434(\mathrm{OH}$ tautomer of $\mathrm{C}=\mathrm{O}) ;{ }^{1} \mathrm{H}-\mathrm{NMR}\left[\left(\mathrm{CD}_{3}\right)_{2} \mathrm{SO}-\mathrm{d}_{6}\right]: \delta 2.68(3 \mathrm{H}, \mathrm{s}, 9-\mathrm{Me}), 3.25-3.27(4 \mathrm{H}$, $\mathrm{m}, 2^{\prime}$ and $\left.6^{\prime}-\mathrm{NCH}_{2}\right), 3.44\left(1 \mathrm{H}, \mathrm{br} \mathrm{s}, \mathrm{OH}, \mathrm{D}_{2} \mathrm{O}\right.$ exchangeable $), 3.94-3.96\left(4 \mathrm{H}, \mathrm{m}, 3^{\prime}\right.$ and $\left.5^{\prime}-\mathrm{NCH}_{2}\right), 6.89$ $\left(1 \mathrm{H}, \mathrm{dt}, J_{3^{\prime \prime}, 4^{\prime \prime}}=J_{4^{\prime \prime}, 5^{\prime \prime}}=7.8 \mathrm{~Hz}, J_{2^{\prime \prime}, 4^{\prime \prime}}=J_{4^{\prime \prime}, 6^{\prime \prime}}=2.3 \mathrm{~Hz}, \mathrm{Ph}-\mathrm{pH}\right), 6.97\left(2 \mathrm{H}, \mathrm{dd}, J_{2^{\prime \prime}}, 3^{\prime \prime}=J_{5^{\prime \prime}}, 6^{\prime \prime}=7.8 \mathrm{~Hz}\right.$, $J_{2^{\prime \prime}, 4^{\prime \prime}}=J_{4^{\prime \prime}, 6^{\prime \prime}}=2.3 \mathrm{~Hz}$, Ph-oH), 7.17-7.24 $(2 \mathrm{H}, \mathrm{m}, \mathrm{Ph}-\mathrm{mH}), 7.38\left(1 \mathrm{H}, \mathrm{t}, J_{6,7}=J_{7,8}=8.1 \mathrm{~Hz}, 7-\mathrm{H}\right), 7.62$ $\left(1 \mathrm{H}, \mathrm{d}, J_{7,8}=8.1 \mathrm{~Hz}, 8-\mathrm{H}\right), 7.91\left(1 \mathrm{H}, \mathrm{d}, J_{6,7}=8.1 \mathrm{~Hz}, 6-\mathrm{H}\right), 8.93(1 \mathrm{H}, \mathrm{s}, 5-\mathrm{H}) ; \%$ CHN analysis: Anal. Calcd for $\mathrm{C}_{22} \mathrm{H}_{21} \mathrm{~N}_{5} \mathrm{O}: \mathrm{C}, 71.14 ; \mathrm{H}, 5.70 ; \mathrm{N}, 18.85$. Found: $\mathrm{C}, 69.95 ; \mathrm{H}, 5.42 ; \mathrm{N}, 19.12$.

3.1.4. General Procedure for the Preparation of 2-Aminopyrimido[4,5-b]quinoline-4(3H)-ones \{2-amino-2-deoxo-5-deazaalloxazines $\}(5 a, b)$

A mixture of 2-(methylthio)pyrimido[4,5- $b$ ]quinolin-4(3H)-one derivative $(2,4.0 \mathrm{mmole})$ and ammonium acetate $\left(0.2\right.$ mole) were mixed thoroughly and fused at $160-165^{\circ} \mathrm{C}$ with a vigorous stirring for $0.5-3.0 \mathrm{~h}$. The reaction mixture was refrigerated, mixed with $15 \mathrm{~mL}$ of water, neutralized with aqueous ammonia and cooled overnight in refrigerator. The resulting brown crystals were collected by filtration, dried and recrystallized from DMF to give $\mathbf{5 a}, \mathbf{b}$ as brown needles in $69 \%$ and $83 \%$ yields.

2-Aminopyrimido[4,5-b]quinolin-4(3H)-one (5a): Yield (0.70 g, 83\%, DMF); m.p. $>300{ }^{\circ} \mathrm{C}$; UV (EtOH): $\lambda_{\max } \mathrm{nm}\left(\log \varepsilon / \mathrm{dm}^{3} \mathrm{~mol}^{-1} \mathrm{~cm}^{-1}\right): 260 \mathrm{sh}(4.05), 274$ (4.06), 302 (3.94), 401 (3.07); IR $\left(v_{\mathrm{cm}}{ }^{-1}\right): 3206,3050$ $(\mathrm{NH}), 1681(\mathrm{C}=\mathrm{O}) ;{ }^{1} \mathrm{H}-\mathrm{NMR}\left[\left(\mathrm{CD}_{3}\right)_{2} \mathrm{SO}-\mathrm{d}_{6}\right]: \delta 6.72\left(2 \mathrm{H}, \mathrm{br} \mathrm{s}, \mathrm{NH}, \mathrm{D}_{2} \mathrm{O}\right.$ exchangeable $), 7.41-7.43(1 \mathrm{H}, \mathrm{m}$, 7-H), 7.68-7.71 (2H, m, 6 and 8-H), 7.71-7.73 $(1 \mathrm{H}, \mathrm{m}, 9-\mathrm{H}), 9.01(1 \mathrm{H}, \mathrm{s}, 5-\mathrm{H}), 10.81\left(1 \mathrm{H}, \mathrm{br} \mathrm{s}, \mathrm{NH}, \mathrm{D}_{2} \mathrm{O}\right.$ exchangeable); \% CHN analysis: Anal. Calcd for $\mathrm{C}_{11} \mathrm{H}_{8} \mathrm{~N}_{4} \mathrm{O}: \mathrm{C}, 62.26 ; \mathrm{H}, 3.80 ; \mathrm{N}, 26.40$. Found: $\mathrm{C}$, 61.94; H, 4.02; N, 26.21; MSEI, $m / z$ (\%): $213\left(\mathrm{M}^{+}+1,4 \%\right), 55$ (100\%).

2-Amino-9-(methyl)pyrimido[4,5-b]quinolin-4(3H)-one (5b): Yield (0.62 g, 69\%, DMF); m.p. $>300{ }^{\circ} \mathrm{C}$; UV (EtOH): $\lambda_{\max } \mathrm{nm}\left(\log \varepsilon / \mathrm{dm}^{3} \mathrm{~mol}^{-1} \mathrm{~cm}^{-1}\right): 246$ (4.13), 283sh (3.89), 334 (3.46), 401 (3.07); IR $\left(v_{\mathrm{cm}^{-1}}\right)$ : 3275, $3060(\mathrm{NH}), 1678(\mathrm{C}=\mathrm{O}) ;{ }^{1} \mathrm{H}-\mathrm{NMR}\left[\left(\mathrm{CD}_{3}\right)_{2} \mathrm{SO}-\mathrm{d}_{6}\right]: \delta 2.64(3 \mathrm{H}, \mathrm{s}, 9-\mathrm{Me}), 6.74\left(2 \mathrm{H}, \mathrm{br} \mathrm{s}, 2-\mathrm{NH}_{2}\right.$, exchangeable with $\left.\mathrm{D}_{2} \mathrm{O}\right), 7.36\left(1 \mathrm{H}, t, J_{6,7}=J_{7,8}=6.8 \mathrm{~Hz}, 7-\mathrm{H}\right), 7.64\left(1 \mathrm{H}, d_{,} J_{7,8}=6.8 \mathrm{~Hz}, 8-\mathrm{H}\right), 7.90(1 \mathrm{H}, d$, $\left.J_{6,7}=6.8 \mathrm{~Hz}, 6-\mathrm{H}\right), 8.87(1 \mathrm{H}, \mathrm{s}, 5-\mathrm{H}), 11.18\left(1 \mathrm{H}, \mathrm{br} \mathrm{s}, \mathrm{NH}, \mathrm{D}_{2} \mathrm{O}\right.$ exchangeable); \% CHN analysis: Anal. Calcd for $\mathrm{C}_{12} \mathrm{H}_{10} \mathrm{~N}_{4} \mathrm{O}: \mathrm{C}, 63.71 ; \mathrm{H}, 4.46 ; \mathrm{N}, 24.76$. Found: $\mathrm{C}, 63.94 ; \mathrm{H}, 4.72 ; \mathrm{N}, 24.41 ; \mathrm{MSEI}, \mathrm{m} / z(\%): 226$ $\left(\mathrm{M}^{+}, 100 \%\right), 184(10 \%), 157(18 \%)$.

3.1.5. General Procedure for the Preparation of Pyrimido[4,5-b]quinoline-2,4(1H,3H)diones\{2,4-dioxo-5-deazaalloxzines\} (6a-c)

A mixture of 2-methylthiopyrimido[4,5-b]quinolin-4(3H)-one derivatives (2a, $\mathbf{b}, \mathbf{d}, 0.01$ mole) and $5 \mathrm{M}$ hydrochloric acid $(250 \mathrm{~mL})$ was mixed carefully, then refluxed for $10-15 \mathrm{~h}$. The precipitated yellow crystals were filtered off. The excess acid in the filtrate was removed under vacuo to get the residue. The combined first crop crystals and residue of the filtrate were collected with water then neutralized by aqueous ammonia to $\mathrm{pH} 7$. The precipitated crystals were filtered, washed with water, dried and recrystallized from DMF- $\mathrm{H}_{2} \mathrm{O}$ mixture to afford yellow needles in $62-84 \%$.

Pyrimido[4,5-b]quinoline-2,4-dione (6a): Yield (1.60 g, 75\%, DMF- $\left.\mathrm{H}_{2} \mathrm{O}\right) ;$ m.p. $>300{ }^{\circ} \mathrm{C}$; UV (EtOH): $\lambda_{\max } \mathrm{nm}\left(\log \varepsilon / \mathrm{dm}^{3} \mathrm{~mol}^{-1} \mathrm{~cm}^{-1}\right): 219$ (4.21), 235 (4.18), 252 (4.26), 307 (3.53), 355 (3.37); IR $\left(v_{\mathrm{cm}}{ }^{-1}\right): 3177$, $3066(\mathrm{NH}), 1710,1621(\mathrm{C}=\mathrm{O}) ;{ }^{1} \mathrm{H}-\mathrm{NMR}\left[\left(\mathrm{CD}_{3}\right)_{2} \mathrm{SO}-\mathrm{d}_{6}\right]: \delta 7.56-7.58(1 \mathrm{H}, \mathrm{m}, 7-\mathrm{H}), 7.85-7.88(2 \mathrm{H}, \mathrm{m}, 6$ and $8-\mathrm{H}), 8.16-8.18(1 \mathrm{H}, \mathrm{m}, 9-\mathrm{H}), 9.03(1 \mathrm{H}, \mathrm{s}, 5-\mathrm{H}), 11.39\left(1 \mathrm{H}, \mathrm{br} \mathrm{s}, \mathrm{NH}, \mathrm{D}_{2} \mathrm{O}\right.$ exchangeable $), 11.68(1 \mathrm{H}$, br s, $\mathrm{NH}, \mathrm{D}_{2} \mathrm{O}$ exchangeable); \% $\mathrm{CHN}$ analysis: Anal. Calcd for $\mathrm{C}_{11} \mathrm{H}_{7} \mathrm{~N}_{3} \mathrm{O}_{2}: \mathrm{C}, 61.97 ; \mathrm{H}, 3.31 ; \mathrm{N}, 19.71$. Found: $\mathrm{C}, 61.72 ; \mathrm{H}, 3.06 ; \mathrm{N}, 19.89$.

7-(Methyl)pyrimido[4,5-b]quinoline-2,4-dione (6b): Yield (1.4 g, 62\%, DMF- $\left.\mathrm{H}_{2} \mathrm{O}\right)$; m.p. $>300{ }^{\circ} \mathrm{C}$; UV (EtOH): $\lambda_{\max } \mathrm{nm}\left(\log \varepsilon / \mathrm{dm}^{3} \mathrm{~mol}^{-1} \mathrm{~cm}^{-1}\right)$ : 223(4.15), 240 (4.17), 254 (4.27), 308 (3.49), $363(3.32) ; \operatorname{IR}\left(v_{\mathrm{cm}}{ }^{-1}\right)$ : $3205,3019(\mathrm{NH}), 1703,1615,(\mathrm{C}=\mathrm{O}) ;{ }^{1} \mathrm{H}-\mathrm{NMR}\left[\left(\mathrm{CD}_{3}\right)_{2} \mathrm{SO}-\mathrm{d}_{6}\right]: \delta 2.14(3 \mathrm{H}, \mathrm{s}, 7-\mathrm{Me}), 7.79-7.81(2 \mathrm{H}, \mathrm{m}, 8$, 9-H), $7.94(1 \mathrm{H}, \mathrm{s}, 6-\mathrm{H}), 8.93(1 \mathrm{H}, \mathrm{s}, 5-\mathrm{H}), 11.49\left(1 \mathrm{H}, \mathrm{br} \mathrm{s}, 1-\mathrm{NH}, \mathrm{D}_{2} \mathrm{O}\right.$ exchangeable $), 11.76((1 \mathrm{H}, \mathrm{br} \mathrm{s}$, 
3-NH, $\mathrm{D}_{2} \mathrm{O}$ exchangeable); \% $\mathrm{CHN}$ analysis: Anal. Calcd for $\mathrm{C}_{12} \mathrm{H}_{9} \mathrm{~N}_{3} \mathrm{O}_{2}: \mathrm{C}, 63.43 ; \mathrm{H}, 3.99 ; \mathrm{N}, 18.49$. Found: $\mathrm{C}, 63.69 ; \mathrm{H}, 4.26 ; \mathrm{N}, 18.72$.

9-(Methyl)pyrimido[4,5-b]quinoline-2,4-dione (6c): Yield (1.90 g, 84\%, DMF- $\left.\mathrm{H}_{2} \mathrm{O}\right) ;$ m.p. $>300{ }^{\circ} \mathrm{C}$; UV (EtOH): $\lambda_{\max } \mathrm{nm}\left(\log \varepsilon / \mathrm{dm}^{3} \mathrm{~mol}^{-1} \mathrm{~cm}^{-1}\right): 256$ (4.41), 262 (4.46), 286 (4.16), 360 (3.67); IR $\left(v_{\mathrm{cm}}{ }^{-1}\right): 3217$, $3039(\mathrm{NH}), 1712,1625,(\mathrm{C}=\mathrm{O}) ;{ }^{1} \mathrm{H}-\mathrm{NMR}\left[\left(\mathrm{CD}_{3}\right)_{2} \mathrm{SO}-\mathrm{d}_{6}\right]: \delta 2.17(3 \mathrm{H}, \mathrm{s}, 9-\mathrm{Me}), 7.08-7.11(1 \mathrm{H}, \mathrm{m}, 7-\mathrm{H})$, 7.20-7.23 (1H, m, 8-H), 7.26-7.28 (1H, m, 6-H), 8.96 (1H, s, 5-H), 10.93 (1H, br s, 1-NH, $\mathrm{D}_{2} \mathrm{O}$ exchangeable), $11.34\left(1 \mathrm{H}\right.$, br s, 3-NH, $\mathrm{D}_{2} \mathrm{O}$ exchangeable); \% CHN analysis: Anal. Calcd for $\mathrm{C}_{12} \mathrm{H}_{9} \mathrm{~N}_{3} \mathrm{O}_{2}: \mathrm{C}, 63.43 ; \mathrm{H}$, 3.99; N, 18.49. Found: C, 63.39; H, 4.27; N, 18.78 .

\subsubsection{General Procedure for the Preparation of 6-(o-tolylamino)pyrimidin-4(3H)-one (7)}

To a stirring solution of Raney nickel catalyst $(8.0 \mathrm{~g}, 0.14 \mathrm{~mol})$ in absolute ethanol $(100 \mathrm{~mL})$, 6-(N-o-Tolylamino)-2-methylthiopyrimidin-4(3H)-one (1d, $0.98 \mathrm{~g}, 4 \mathrm{mmole})$ was added and the mixture was heated under reflux for $0.5 \mathrm{~h}$. The mixture was filtered while hot to remove the catalyst which was washed well with boiling absolute ethanol $(4 \times 20 \mathrm{~mL})$. The combined filtrate and washings were evaporated to dryness. The residue was recrystallized from DMF, to afford $0.56 \mathrm{~g}$ of compound 7 as colorless needles in $70 \%$ yield; m.p. $152-154{ }^{\circ} \mathrm{C}$; UV (EtOH): $\lambda_{\max } \mathrm{nm}\left(\log \varepsilon / \mathrm{dm}^{3} \mathrm{~mol}^{-1} \mathrm{~cm}^{-1}\right)$ : 242 (4.12), 276 (3.93);IR $\left(v_{\mathrm{cm}}{ }^{-1}\right): 3405,3210(\mathrm{NH}), 1637(\mathrm{C}=\mathrm{O}) ;{ }^{1} \mathrm{H}-\mathrm{NMR}\left[\left(\mathrm{CD}_{3}\right)_{2} \mathrm{SO}-\mathrm{d}_{6}\right]: \delta 2.18(3 \mathrm{H}$, s, Ph-oMe), 4.83 (1H, s, 5-H), 7.11-7.28 (4H, m, Ph-o,m,pH), 7.80 (1H, s, 2-H), 8.53 (1H, br s, 6-NH, $\mathrm{D}_{2} \mathrm{O}$ exchangeable), $11.60\left(1 \mathrm{H}\right.$, br s, 3- $\mathrm{NH}, \mathrm{D}_{2} \mathrm{O}$ exchangeable); \% CHN analysis: Anal. Calcd for $\mathrm{C}_{11} \mathrm{H}_{11} \mathrm{~N}_{3} \mathrm{O} .0 .4 \mathrm{H}_{2} \mathrm{O}: \mathrm{C}, 63.39 ; \mathrm{H}, 5.71 ; \mathrm{N}, 20.16$. Found: $\mathrm{C}, 63.13 ; \mathrm{H}, 6.08 ; \mathrm{N}, 19.85$.

3.1.7. General Procedure for the Preparation of 9-(methyl)pyrimido[4,5-b]quinolin-4-ol \{2-deoxo-5-deazaalloxazine\} (8)

A mixture of 6-(o-tolylamino)pyrimidin-4(3H)-one (7, $2 \mathrm{~g}, 0.01$ mole) and $\mathrm{POCl}_{3}(7.7 \mathrm{~g}, 0.05$ mole) in anhydrous DMF $(10 \mathrm{~mL})$ was heated at $90{ }^{\circ} \mathrm{C}$ with stirring for $2 \mathrm{~h}$. Followed by pouring the mixture onto ice and then neutralized to $\mathrm{pH} 7$ by with aqueous ammonia. The product of yellow crystals was filtered off, washed with cold water, dried and recrystallized from mixture of DMF- $\mathrm{H}_{2} \mathrm{O}$ to give $1.70 \mathrm{~g}$. of compound 8 as pale yellow needles in $80 \%$ yield; m.p. $249-251^{\circ} \mathrm{C} ; \mathrm{UV}(\mathrm{EtOH}): \lambda_{\max } \mathrm{nm}\left(\log \varepsilon / \mathrm{dm}^{3}\right.$ $\left.\mathrm{mol}^{-1} \mathrm{~cm}^{-1}\right)$ : 250 (4.18), 278sh (4.08), 336 (3.55), $365(3.44)$; IR $\left(v_{\mathrm{cm}^{-1}}\right)$ : $3411(\mathrm{OH}$ tautomer of $\mathrm{C}=\mathrm{O})$; ${ }^{1} \mathrm{H}-\mathrm{NMR}$ [ $\left.\left(\mathrm{CD}_{3}\right)_{2} \mathrm{SO}-\mathrm{d}_{6}\right]: \delta 2.26(3 \mathrm{H}, \mathrm{s}, 9-\mathrm{Me}), 4.01\left(1 \mathrm{H}, \mathrm{br} \mathrm{s}, 4-\mathrm{OH}, \mathrm{D}_{2} \mathrm{O}\right.$ exchangeable), $6.53(1 \mathrm{H}, \mathrm{s}$, 2-H), $7.54\left(1 \mathrm{H}, \mathrm{t}, J_{6,7}=J_{7,8}=7.2 \mathrm{~Hz}, 7-\mathrm{H}\right), 7.80\left(1 \mathrm{H}, \mathrm{d}, J_{7,8}=7.2 \mathrm{~Hz}, 8-\mathrm{H}\right), 8.09\left(1 \mathrm{H}, \mathrm{d}, J_{6,7}=7.2 \mathrm{~Hz}, 6-\mathrm{H}\right)$, $9.23(1 \mathrm{H}, \mathrm{s}, 5-\mathrm{H}) ; \% \mathrm{CHN}$ analysis: Anal. Calcd for $\mathrm{C}_{12} \mathrm{H}_{9} \mathrm{~N}_{3} \mathrm{O}: \mathrm{C}, 68.24 ; \mathrm{H}, 4.29 ; \mathrm{N}, 19.89$. Found: $\mathrm{C}$, 68.66; H, 3.96; N, 20.09; MSEI, $m / z(\%): 211\left(\mathrm{M}^{+}, 100 \%\right), 184(24 \%), 155(49 \%)$ and $129(34 \%)$.

\subsection{Antiproliferative MTT Assay}

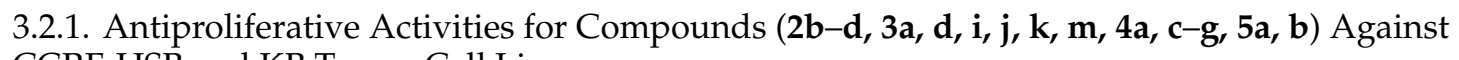
CCRF-HSB and KB Tumor Cell Lines

Four human cancer cell lines were utilized in this study to carry out cell proliferation assay, including CCRF-HSB-2, KB, MCF-7 and HeLa cell lines. The cell culture was conducted at $37{ }^{\circ} \mathrm{C}$, at $5 \%$ $\mathrm{CO}_{2}, 95 \%$ air and $100 \%$ relative humidity. The use of the cancer cell lines was limited to 20 passages and was checked regularly for Mycoplasma. The modified MTT assay [31] developed by M. Tim [32] was used to determine the in vitro antiproliferative effects of our test compounds against the tumor cell lines. The culture media containing the cancer cell lines were seeded in 96-well microplate at a density of $5 \times 10^{3}$ cells per each well in $100 \mu \mathrm{L}$ of culture medium. Cells were incubated at $37^{\circ} \mathrm{C}$ overnight to allow cell attachment. The test compounds were seeded in triplicates to the wells to get the final concentrations of each compound as $0.0,0.005,0.05,0.5,5,25$ and $50 \mu \mathrm{M} / \mathrm{mL}$ in $100 \mu \mathrm{L}$ of media $(0.1 \%$ DMSO for the blank control). After the incubation, $10 \mu \mathrm{L}$ of MTT solution (10 mg/mL solution) was added to each well. Then incubated for $4 \mathrm{~h}$ at $37^{\circ} \mathrm{C}, 100 \mu \mathrm{L}$ of $0.02 \mathrm{~N} \mathrm{HCl}, 50 \% \mathrm{DMF}$ and $20 \%$ SDS was used to dissolve the formed MTT-formazan (if any). Plates were shaken for $1 \mathrm{~min}$ and the absorbance 
was examined using a multi-plate reader at $\lambda_{570} \mathrm{~nm}$. The $\mathrm{IC}_{50}(50 \%$ growth inhibition) was determined from the dose-response curve based on the equation: $(1-T / C) \times 100$, where $C$ is the mean $\mathrm{OD}_{570}$ of the control group and $T$ is that of the treated group.

\subsubsection{Antiproliferative Activities for Compounds ( $\mathbf{2} b-\mathbf{e}, \mathbf{3 b}, \mathbf{c}, \mathbf{e}, \mathbf{f}, \mathbf{g}, \mathbf{h}, \mathbf{1}, \mathbf{4 b}, \mathbf{6 a}-\mathbf{c}, \mathbf{8})$ Against MCF-7} and HeLa Tumor Cell Lines

Cells were seeded onto sterile 96-well cell culture plates at densities of $5 \times 10^{3} /$ well for HeLa cells and $2 \times 10^{4} /$ well for MCF-7 cells. Cells were incubated at $37^{\circ} \mathrm{C}$ and $5 \% \mathrm{CO}_{2}$ for $24 \mathrm{~h}$, after which media was aspirated from cells and $100 \mu \mathrm{L}$ fresh media with/without treatments were added. Control wells were treated by media with DMSO concentrations equivalent to those of treatment peptides. Cells were further incubated at $37{ }^{\circ} \mathrm{C}$ and $5 \% \mathrm{CO}_{2}$ for $72 \mathrm{~h}$, followed by the addition of MTT (10 $\mu \mathrm{L}$ of a $10 \mathrm{mg} / \mathrm{mL}$ solution) to each well. Following $2 \mathrm{~h}$ incubation of the plate at $37^{\circ} \mathrm{C}$ and $5 \% \mathrm{CO}_{2}$ and shielded from light with tin foil, the media was removed and the produced formazan crystals were solubilized by the addition of $200 \mu \mathrm{L}$ of DMSO. The optical density of each well was measured quantitatively at $570 \mathrm{~nm}\left(\mathrm{OD}_{570}\right)$ by EL808 HiTeck ${ }^{\mathrm{TM}}$ Spectra Thermo plate reader (HiTek Instruments, USA). The $\mathrm{IC}_{50}$ (50\% growth inhibition) was determined from the dose-response curve based on the equation: $\left(1-^{\prime} T / C\right) \times 100$, where $C$ is the mean $\mathrm{OD}_{570}$ of the control group and $T$ is that of the treated group.

\subsection{3. $\left[\gamma^{-32} \mathrm{P}\right]$ ATP Radiometric Protein Kinase Assay Method}

The protein kinase profiling for compound ( $3 \mathbf{h}$ ) was carried out following the protocol of KINEXUS Bioinformatics Corporation, Vancouver, British Columbia, Canada. This assay was applied for a single measurement at $10 \mu \mathrm{M}$ concentration by $\left[\gamma_{-}{ }^{32} \mathrm{P}\right] \mathrm{ATP}$ radioisotope against a panel of 20 protein kinases. Both Imatinib and lapatinib were used as positive references at the same concentration. All experiments have been conducted in a designated radioactive environment and at ambient temperature for $30 \mathrm{~min}$ in a total volume of $25 \mu \mathrm{L}$ in the following sequence: component 1:5.0 $\mu \mathrm{L}$ of the active kinase $(\sim 10-50$ $\mathrm{nM}$ final concentration), component 2:5.0 $\mu \mathrm{L}$ of the substrate solution. component 3: 5.0 $\mu \mathrm{L}$ of a buffer, component 4: $5.0 \mu \mathrm{L}$ of test and reference at different concentrations or 10\% DMSO as a blank control, component 5: $5.0 \mu \mathrm{L}$ of $\left[\gamma_{-}{ }^{32} \mathrm{P}\right] \mathrm{ATP}$ (from $50 \mu \mathrm{M}$ stock solution, $0.8 \mu \mathrm{Ci}$ ). This assay was started with the addition of $\left[\gamma^{-32} \mathrm{P}\right]$ ATP to a mixture of other components then incubation for $30 \mathrm{~min}$. The reaction was terminated by adding $10 \mu \mathrm{L}$ of the mixture onto a MultiScreen phosphocellulose P81 plate, washing $3 \times$ by $1 \%$ solution of phosphoric acid solution. Using a Trilux scintillation counter, the radioactivity was measured for the test samples in comparison to the blank control which contains all components except that the kinase substrate was replaced by the buffer solution.

\subsection{Annexin V PI/FITC Apoptosis Assay Using MCF7 Cells}

Cell apoptosis assay using MCF7 breast cancer cell lines $(1 \times 105$ cells/well $)$ was carried out by flow cytometry as described [41]. Briefly, MCF7 breast cancer cells were harvested by trypsinization and washed with ice-cold PBS ( $\mathrm{pH} 7.4$ ) twice following treatment with the test compound (3h) at final concentrations of $0,1,5,10 \mu \mathrm{M}$ for $72 \mathrm{~h}$. Cells have been subsequently incubated with $0.5 \mathrm{~mL}$ of Annexin V-FITC/ Propidium iodide (PI) $(1.0 \mathrm{mg} / \mathrm{mL})$ solution for $30 \mathrm{~min}$ in dark at room temperature following the manufacturer's protocol. The MCF7 cells were microscopically examined for any potential morphological changes before and after treatment. The floating cells were harvested in tubes and kept on ice, whereas, the remaining cells have been trypsinized to be detached then incubated for $3 \mathrm{~min}$ at $37^{\circ} \mathrm{C}$ and pooled. At $1200 \mathrm{RPM}$ at a fixed temperature of $40{ }^{\circ} \mathrm{C}$, the cells were centrifuged and the supernatants have been discarded with adding $2 \mathrm{~mL}$ fresh medium to each tube. Compound $3 \mathrm{~h}$ at different concentrations was inoculated using $23 \mathrm{G}$ needle and $1 \times 105 \mathrm{MCF} 7$ cells were transferred to new tubes of $12 \times 75 \mathrm{~mm}$ tubes. The cell solutions were washed with1 $\mathrm{mL}$ PBS and again centrifuged, followed by discarding the supernatants and re-suspending the pellets in $100 \mu \mathrm{L} \times 1$ binding buffer (10 mM HEPES). The stained cells were injected through Becton Dickinson FACScan flow cytometer 
(BD Biosciences, San Jose, CA, USA) and analyzed for Fluorescein Isothiocyanate-Propidium Iodide (FITC and PI) fluorescent signals using FL1 and FL2 signal detector, respectively ( $\lambda$ ex/em 488/530 nm for FITC and $\lambda$ ex/em 535/617 nm for PI). For each sample, 12,000 events were acquired and positive FITC and/or PI cells were quantified by quadrant analysis and calculated using CellQuest Software. The percentage of apoptosis was calculated according to the reported protocol [42] using the equation: (Sample-Control)/Control $\times 100$ to determine the apoptosis and necrosis of the cell populations.

\subsection{Molecular Docking Study}

Autodock 4.2 [38], a molecular grid-based docking program, was used for flexible docking of a fully flexible ligand into a partially flexible protein structure. Autodock scans the binding site looking for the lowest energy binding energy model (s). In this study, the target kinase (PDB code, 1t46) [39] was retrieved solely by using ADS (Accelrys Discovery Studio) visualize v4.0 software (Accelrys Inc., San Diego, CA, USA). The Grid was selected to enclose the native ligand, STI-571 (Imatinib). For each of the docked compounds, the results of top docked runs were analyzed and assigned to the same cluster if their atomic coordinates have a root mean square deviation (RMSD) tolerance of $0.5 \AA$. Then these clusters were rated from the lowest binding energy to the highest. The analysis was further conducted for the top 10 clusters which revealed significant negative binding energies.

\subsubsection{Preparation of Target C-Kit Kinase and Ligands}

The 3D structures (PDB format) of the test compounds were constructed using Chem3D Ultra 18.1 software [Cambridge Soft Corporation, USA (2019)]. These structures were energetically minimized by the use of the MOPAC package with 100 iterations and an RMS gradient of 0.10. Before operating with AutoDock Tool (ADT), all hydrogen atoms were added to the 3D protein structures and the ligands as well. Besides, Gasteigercharges (empirical atomic partial charges) were automatically computed by ADT on opening the ligands. To afford all different docking possibilities (conformers), the AutoDock program identifies all the rotatable bonds of the docked ligands. The 3D structure of c-Kit tyrosine kinase in complex with its co-crystallized ligand (STI-571; Imatinib) was retrieved as PDB format from the Protein Data Bank (PDB) web site: https://www.rcsb.org/. Then, all $\mathrm{H}_{2} \mathrm{O}$ molecules, bound ligands were removed deleted from the protein structure. Three amino acids, namely: Glu640, Thr670 and Asp810 were utilized as flexible residues during the docking protocol. The polar hydrogen atoms were added and the Kollman charges were automatically loaded for the protein 3D structure.

\subsubsection{Calculation of Autogrid Maps for the C-Kit Kinase Embracing the STI-571 Ligand}

Prior to running the docking, AutoGrid maps should be developed. These maps estimate the non-covalent interactions energy between the target c-kit kinase and all probe atoms in different grid points in the macromolecule where the ligand potentially binds. AutoGrid creates about 30 different types of grid maps. The created 3D grids of dimensions of $60 \times 60 \times 60 \AA$ size $(x, y, z)$ and 0.375 $\AA$ spacing centered at $27.696,26.657$ and $39.342 \AA$ encompassing the binding site of the assigned kinase where the co-crystallized ligand; STI-571 was embedded. These grid maps were used to guide the docked ligands into the binding site of the c-kit kinase. Accordingly, in the Autogrid process, the size and position $(X, y, z)$ of the grid box will be determined. Once these parameters have been set, AutoGrid will calculate the grid parameter files for each type of atom within a given area. Followed by running of AutoDock to automatically perform the main docking process using a Lamarckian Genetic Algorithm to generate all possible poses.

As a consequence of AutoDock calculations, the output file with the top 10 conformers of the c-kit kinase-ligand interaction will be generated with different orientations of the flexible residues and the ligands within the binding site. Each pose will be scored by Autodock then ranked according to their binding free energy of interaction. 


\section{Conclusions}

In this study, we synthesized and investigated different 5-deazaalloxazine analogs in vitro for their antiproliferative activities against four tumor cell lines, namely CCRF-HSB-2, KB, MCF-7 and HeLa. It was noticed that compounds $(\mathbf{2 b}, \mathbf{2 c}, \mathbf{3 e}, \mathbf{3 f}, \mathbf{3 g}, \mathbf{4 b}, \mathbf{6 a}$ and $\mathbf{6 c})$ show high selective antiproliferative activity against MCF-7 over HeLa tumor cell lines of $\mathrm{IC}_{50}: 0.22-2.17 \mu \mathrm{M}$ and $>100 \mu \mathrm{M}$, respectively. Whereas, other analogs showed the opposite $\left(\mathrm{IC}_{50}\right.$ against HeLa cell lines: $0.33-1.39 \mu \mathrm{M}$ and $\mathrm{IC}_{50}$ against MCF-7 cell lines: $8.49>100 \mu \mathrm{M}$ ). On the other hand, Compound 5a exhibited high selective activity against $\mathrm{KB}$ over CCRF-HSB-2 tumor cell lines of $\mathrm{IC}_{50}: 1.46 \mu \mathrm{M}$ and $>100 \mu \mathrm{M}$, respectively.

Particularly, the most promising lead candidate from our synthesized compounds is 2-(2-hydroxyethylamino)-7-methyl-pyrimido[4,5-b] quinolin-4(3H)-one analog (3h), which revealed significant antitumor activities against both of MCF-7 and HeLa tumor cell lines of $\mathrm{IC}_{50} 0.17 \mu \mathrm{M}$ and $2.00 \mu \mathrm{M}$, respectively. Additionally, PKs target study of compound $3 \mathrm{~h}$ illustrated that the compound $3 \mathrm{~h}$ induced multi- targets kinase inhibition including $-43 \%$ against (FAK), $-40 \%$ against (CDKI) and $-36 \%$ against (SCR). Moreover, the Annexin-V/PI apoptotic assay elucidate that compound 3h showed $33 \%$ and potentially $140 \%$ increase in early and late apoptosis to MCF-7 cells respectively at $10 \mu \mathrm{M}$, compared to the control. The AutoDock study of different synthesized compounds was conducted for lead optimization. Nonetheless, the docking result of compound $\mathbf{2} \mathbf{b}$ indicates that this compound is predicted to be a significant lead compound for PTK inhibition by its appropriate fitting into the binding site of c-Kit Kinase. This result is considerable correlated with antiproliferative activity of compound ( $\mathbf{2 b}$ ) against MCF-7 cancer cell line with $1.79 \mu \mathrm{M}$. Herein, we are potentially suggested that the compound $(3 \mathrm{~h})$ considerably a promising lead in comparison to the deazaalloxazine derivatives.

Supplementary Materials: The following are available online.

Author Contributions: Participated in research design: H.I.A. and M.S.M. Conducted experiments: S.M. and M.A.E. Performed data analysis: N.A.A.T., T.N., D.S., and H.I.A. Wrote or contributed to the writing of the manuscript: H.I.A., S.M., and M.S.M. All authors have read and agreed to the published version of the manuscript.

Funding: This research received no external funding.

Acknowledgments: This work was supported in part by the startup fund by Texas A\&M Health Sciences Center (to H.I.A.; grant number: 121500-35558). The authors wish to offer their deep gratitude to Noriyuki Ashida in the Biology Laboratory, Research and Development Division, Yamasa Shoyu Co., Choshi, Chiba, Japan for his help in the MTT assay. Also, we wish to our gratitude for the financial support to John A. King foundation for sponsoring M.A.E. (Ph.D. studentship), School of Pharmacy, Queen's University of Belfast.

Conflicts of Interest: Authors declared that there is no actual or potential conflict of interest and have approved the article.

\section{References}

1. American Cancer Society. Cancer Statistics Center. 2020. Available online: https://cancerstatisticscenter. cancer.org/\#!/ (accessed on 26 May 2020).

2. Paul, M.K.; Mukhopadhyay, A.K. Tyrosine kinase-role and significance in cancer. Int. J. Med. Sci. 2004, 1, 101-115. [CrossRef]

3. Burke, T.R., Jr.; Yao, Z.J.; Liu, D.G.; Voigt, J.; Gao, Y. Phosphoryltyrosyl mimetics in the design of peptide-Based signal transduction inhibitors. Biopolymers 2001, 60, 32-44. [CrossRef]

4. Cohen, M.H.; Williams, G.; Johnson, J.R.; Duan, J.; Gobburu, J.; Rahman, A.; Benson, K.; Leighton, K.J.; Kim, S.K.; Wood, R.; et al. Approval summary for imatinib mesylate capsules in the treatment of chronic myelogenous leukemia. Clin. Cancer Res. 2002, 8, 935-942. [PubMed]

5. Jiao, Q.; Bi, L.; Ren, Y.; Song, S.; Wang, Q.; Wang, Y.S. Advances in studies of tyrosine kinase inhibitors and their acquired resistance. Mol. Cancer. 2018, 17, 36-48. [CrossRef]

6. Ali, H.I.; Tomita, K.; Akaho, E.; Kambara, H.; Miura, S.; Hayakawa, H.; Yoneda, F. Antitumor studies. Part 1: Design, synthesis, antitumor activity and AutoDock study of 2-deoxo-2-phenyl-5-deazaflavins and 2-deoxo-2-phenylflavin-5-oxides as a new class of antitumor agents. Bioorgan. Med. Chem. 2007, 15, 242-256. [CrossRef] [PubMed] 
7. Ali, H.I.; Tomita, K.; Akaho, E.; Kunishima, M.; Kawashima, Y.; Yamagishi, T.; Nagamatsu, T. Antitumor studies-Part 2: Structure-activity relationship study for flavin analogs including investigations on their in vitro antitumor assay and docking simulation into protein tyrosine kinase. Eur. J. Med. Chem. 2008, 43, 1376-1389. [CrossRef] [PubMed]

8. Ali, H.I.; Ashida, N.; Nagamatsu, T. Antitumor studies. Part 4: Design, synthesis, antitumor activity and molecular docking study of novel 2-substituted 2-deoxoflavin-5-oxides, 2-deoxoalloxazine-5-oxides and their 5-deaza analogs. Bioorgan. Med. Chem. 2008, 16, 922-940. [CrossRef]

9. Ghorab, M.M.; Ragab, F.A.; Heiba, H.I.; Ghorab, W.M. Design and synthesis of some novel quinoline derivatives as anticancer and radiosensitizing agents targeting VEGFR tyrosine kinase. J. Het. Chem. 2011, 48, 1269-1279. [CrossRef]

10. Berezovskii, V.M.; Eremenko, T.V. Chemistry of alloxazines and isoalloxazines. Russ. Chem. Rev. 1963, 32, 290-307. [CrossRef]

11. Talele, T.T.; Khedkar, S.A.; Rigby, A.C. Successful applications of computer aided drug discovery: Moving drugs from concept to the clinic. Curr. Top. Med. Chem. 2010, 10, 127-141. [CrossRef]

12. Leelananda, S.P.; Lindert, S. Computational methods in drug discovery. Beilstein. J. Org. Chem. 2016, 12, 2694-2718. [CrossRef] [PubMed]

13. Woolfrey, J.R.; Weston, G. The use of computational methods in the discovery and design of kinase inhibitors. Curr. Pharm. Des. 2002, 8, 1527-1545. [CrossRef] [PubMed]

14. Gagic, Z.; Ruzic, D.; Djokovic, N.; Djikic, T.; Nikolic, K. In silico methods for design of kinase inhibitors as anticancer drugs. Front. Chem. 2019, 7, 873-898. [CrossRef]

15. Wong, Y.H.; Chiu, C.C.; Lin, C.L.; Chen, T.S.; Jheng, B.R.; Lee, Y.C.; Chen, J.; Chen, B.S. A new era for cancer target therapies: Applying systems biology and computer-aided drug design to cancer therapies. Curr. Pharm. Biotechnol. 2016, 17, 1246-1267. [CrossRef]

16. Basith, S.; Cui, M.; Macalino, S.J.; Choi, S. Expediting the design, discovery and development of anticancer drugs using computational approaches. Curr. Med. Chem. 2017, 24, 4753-4778. [CrossRef]

17. De, B.; Bhandari, K.; Mendonça, F.J.; Scotti, M.T.; Scotti, L. Computational studies in drug design against cancer. Anti-Cancer Agents Med. Chem. (Formerly Curr. Med. Chem. Anti-Cancer Agents) 2019, 19, 587-591. [CrossRef]

18. Cichero, E.; D’Ursi, P.; Moscatelli, M.; Bruno, O.; Orro, A.; Rotolo, C.; Milanesi, L.; Fossa, P. Homology modeling, docking studies and molecular dynamic simulations using graphical processing unit architecture to probe the type-11 phosphodiesterase catalytic site: A computational approach for the rational design of selective inhibitors. Chem. Boil. Drug Des. 2013, 82, 718-731. [CrossRef]

19. Franchini, S.; Battisti, U.M.; Prandi, A.; Tait, A.; Borsari, C.; Cichero, E.; Fossa, P.; Cilia, A.; Prezzavento, O.; Ronsisvalle, S.; et al. Scouting new sigma receptor ligands: Synthesis, pharmacological evaluation and molecular modeling of 1, 3-dioxolane-based structures and derivatives. Eur. J. Med. Chem. 2016, 112, 1-19. [CrossRef]

20. Rusnati, M.; Sala, D.; Orro, A.; Bugatti, A.; Trombetti, G.; Cichero, E.; Urbinati, C.; Somma, M.D.; Millo, E.; Galietta, L.J.V.; et al. Speeding up the identification of cystic fibrosis transmembrane conductance regulator-targeted drugs: An approach based on bioinformatics strategies and surface plasmon resonance. Molecules 2018, 23, 120. [CrossRef]

21. Chen, Y.C. Beware of docking. Trends Pharmacol. Sci. 2015, 36, 78-95. [CrossRef]

22. Kimachi, T.; Yoneda, F.; Sasaki, T. New synthesis of 5-amino-5-deazaflavin derivatives by direct coupling of 5-deazaflavins and amines. J. Heterocycl. Chem. 1992, 29, 763-765. [CrossRef]

23. Hall, L.H.; Orchard, B.J.; Tripathy, S.K. The structure and properties of flavins: Molecular orbital study based on totally optimized geometries. II. Molecular orbital structure and electron distribution. Int. J. Quantum C. 1987, 31, 217-242. [CrossRef]

24. Dow, R.L.; Bechle, B.M.; Chou, T.T.; Goddard, C.; Larson, E.R. Selective inhibition of the tyrosine kinase pp60src by analogs of 5, 10-dihydropyrimido [4, 5-b] quinolin-4 (1H)-one. Bioorg. Med. Chem. Lett. 1995, 5, 1007-1010. [CrossRef]

25. Ali, H.I.; Ashida, N.; Nagamatsu, T. Antitumor studies. Part 3: Design, synthesis, antitumor activity and molecular docking study of novel 2-methylthio-, 2-amino- and 2-(N-substituted amino)-10-alkyl-2-deoxo-5-deazaflavins. Bioorgan. Med. Chem. 2007, 15, 6336-6352. [CrossRef] 
26. Curran, W.V.; Angier, R.B. Some new syntheses of amino-and alkylaminopyrimidines and pteridines. J. Org. Chem. 1963, 28, 2672-2677. [CrossRef]

27. Taylor, E.C.; Cheng, C.C. Purine Chemistry. VII. An Improved Synthesis of Hypoxanthine. J. Org. Chem. 1960, 25, 148-149. [CrossRef]

28. Mozingo, R.; Wolf, D.E.; Harris, T.A.; Folkers, K. Hydrogenolysis of sulfur compounds by Raney nickel catalyst. J. Am. Chem. Soc. 1943, 65, 1013-1016. [CrossRef]

29. Massey, V. The chemical and biological versatility of riboflavin. Biochem. Soc. Trans. 2000, 28, $283-296$. [CrossRef]

30. Prukata, D.; Sikorski, M. Electron ionization mass spectrometric study of substituted alloxazine-5-oxides and iso-alloxazine-5-oxide. Rapid Commun. Mass Spectrom. 2009, 23, 619-628. [CrossRef]

31. Miura, S.; Yoshimura, Y.; Endo, M.; Machida, H.; Matsuda, A.; Tanaka, M.; Sasaki, T. Antitumor activity of a novel orally effective nucleoside, 1-(2-deoxy-2-fluoro-4-thio- $\beta$-d-arabinofuranosyl) cytosine. Cancer Lett. 1998, 129, 103-110. [CrossRef]

32. Mosmann, T. Rapid colorimetric assay for cellular growth and survival: Application to proliferation and cytotoxicity assays. J. Immunol. Methods 1983, 65, 55-63. [CrossRef]

33. Ali, H.I.; Nagamatsu, T.; Akaho, E. Structurebased drug design and AutoDock study of potential protein tyrosine kinase inhibitors. Bioinform. 2011, 5, 368. [CrossRef] [PubMed]

34. Malki, W.H.; Gouda, A.M.; Ali, H.E.; Al-Rousan, R.; Samaha, D.; Abdalla, A.N.; Ali, H.I. Structural-based design, synthesis and antitumor activity of novel alloxazine analogues with potential selective kinase inhibition. Eur. J. Med. Chem. 2018, 152, 31-52. [CrossRef] [PubMed]

35. Dickens, M.P.; Roxburgh, P.; Hock, A.; Mezna, M.; Kellam, B.; Vousden, K.H.; Fischer, P.M. 5-Deazaflavin derivatives as inhibitors of p53 ubiquitination by HDM2. Bioorgan. Med. Chem. 2013, 21, 6868-6877. [CrossRef] [PubMed]

36. Wilson, J.M.; Henderson, G.; Black, F.; Sutherland, A.; Ludwig, R.L.; Vousden, K.H.; Robins, D.J. Synthesis of 5-deazaflavin derivatives and their activation of p53 in cells. Bioorgan. Med. Chem. 2007, 15, 77-86. [CrossRef] [PubMed]

37. Shi, Q.; Hao, L.; Pei, J.; Yin, W. Promotion of apoptosis does not necessarily mean inhibition of remodeling. Hypertension. 2012, 60, e3. [CrossRef]

38. Morris, G.M.; Huey, R.; Lindstrom, W.; Sanner, M.F.; Belew, R.K.; Goodsell, D.S.; Olson, A.J. AutoDock4 and AutoDockTools4: Automated docking with selective receptor flexibility. J. Comp. Chem. 2009, 30, 2785-2791. [CrossRef]

39. Mol, C.D.; Dougan, D.R.; Schneider, T.R.; Skene, R.J.; Kraus, M.L.; Scheibe, D.N.; Snell, G.P.; Zou, H.; Sang, B.C.; Wilson, K.P. Structural basis for the autoinhibition and STI-571 inhibition of c-Kit tyrosine kinase. J. Biol. Chem. 2004, 279, 31655-31663. [CrossRef]

40. Wang, R.; Lu, Y.; Wang, S. Comparative evaluation of 11 scoring functions for molecular docking. J. Med. Chem. 2003, 46, 2287-2303. [CrossRef]

41. Vermes, I.; Haanen, C.; Steffens-Nakken, H.; Reutelingsperger, C. Flow cytometric detection of phosphatidylserine expression on early apoptotic cells using fluorescein labelled Annexin, V. J. Immunol Methods 1995, 184, 39-51. [CrossRef]

42. Sepehr, K.S.; Baradaran, B.; Mazandarani, M.; Yousefi, B.; Alitappeh, M.A.; Khori, V. Growth-inhibitory and apoptosis-inducing effects of Punica granatum, L. var. spinosa (apple punice) on fibrosarcoma cell lines. Adv. Pharmaceut. Bull. 2014, 4, 583-590.

Sample Availability: Samples of the compounds (2a-e), (3a-m), $(4 \mathbf{a}-\mathbf{g}),(5 \mathbf{a}, \mathbf{b}),(\mathbf{6 a}-\mathbf{c})$, and $(\mathbf{8})$ are available from the authors.

(C) 2020 by the authors. Licensee MDPI, Basel, Switzerland. This article is an open access article distributed under the terms and conditions of the Creative Commons Attribution (CC BY) license (http://creativecommons.org/licenses/by/4.0/). 